\title{
Geology of South-central
}

\section{Hidalgo and Northeastern}

México, Mexico

By KENNETH SEGERSTROM

* GEOLOGIC INVESTIGATIONS IN MEXICO

GEOLOGICAL S URVEY BULLETIN $1104-\mathrm{C}$

Prepared in cooperation with the Instituto Nacional para la Investigación de Recursos Minerales, under the auspices + of the Technical Cooperation Administration of the Department of State and the Foreign Operations Administration

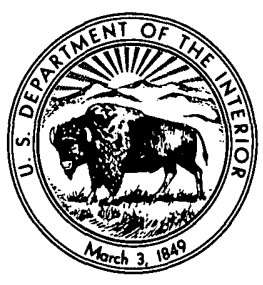



Washington 25 , D.C. 


\section{CONTENTS}

\begin{tabular}{|c|c|}
\hline & Page \\
\hline Abstract_ & 87 \\
\hline Introduction. - & 87 \\
\hline Location . . . & 87 \\
\hline Fieldwork and acknowledgments. & 88 \\
\hline Geography & 89 \\
\hline Accessibility & 89 \\
\hline Topography and drainage & 91 \\
\hline Climate & 92 \\
\hline Vegetation & 92 \\
\hline Agriculture and stockraising & 93 \\
\hline Archeology & 94 \\
\hline Stratigraphy & 95 \\
\hline Jurassic system & 95 \\
\hline Las Trancas formation & 95 \\
\hline Cretaceous system & 97 \\
\hline Santuario formation & 97 \\
\hline El Doctor limestone. & 99 \\
\hline Cuautla formation & 101 \\
\hline formation & 103 \\
\hline nd Méndez formations. & 105 \\
\hline $\mathrm{m}_{-}$ & 108 \\
\hline El Morro fanglomerate. & 108 \\
\hline Pachuca group & 110 \\
\hline and Tezuantla formations and Don Guinyo tuff........ & 113 \\
\hline San Juan group & 115 \\
\hline Tarango and Atotonilco el Grande formations & 118 \\
\hline Quaternary system & 123 \\
\hline Basalt of Pleistocene age & 123 \\
\hline Clastic deposits and soils of Pleistocene and Recent ages........ & 125 \\
\hline Intrusive rocks. & 130 \\
\hline ـ & 131 \\
\hline - & 131 \\
\hline Fracture cleavage & 135 \\
\hline Thrust faults. & 135 \\
\hline Normal faults & 137 \\
\hline (1) & 139 \\
\hline morphology & 140 \\
\hline Erosional forms in rocks of Mesozoic age & 140 \\
\hline Erosional forms in rocks of Cenozoic age & 142 \\
\hline Surfaces of basin-fill deposits & 143 \\
\hline Superposition of streams & 144 \\
\hline Downcutting and stream capture... & 147 \\
\hline Recent deposition along streams. & 149 \\
\hline
\end{tabular}


Geologic history

Mineral deposits

Metals

Nonmetals

Thermal springs.

\section{ILLUSTRATIONS}

Plate 3. Geologic map and sections of south-central Hidalgo and northeastern Mexico, Mexico In pocket

Page

Figure 35. Index map of Mexico

36. Impure limestone and calcareous shale of the Las Trancas formation.

37. Stratigraphic correlation of geologic units in parts of Mecico..

38. Cliffs of $\mathrm{El}$ Doctor limestone along the gorge of the Río de Tonaltongo.

39. The rudistid Hippurites mexicana Bárcena on the weathered surface of a limestone bed

40. Folded limestone beds and shale partings of the Soyatal formation

41. Landslide scars (gray slopes) in the poorly resistant Mendez formation

42. Splintery fracture of the Mexcala or Méndez formation......

43. Well-indurated conglomerate of the El Morro fanglomerate lying unconformably on the El Doctor limestone.......

44. Andesitic flow breccia in the Pachuca group...........

45. Pinnacle composed of explosion breccia of the Zumate formation

46. Weathered surface of Don Guinyó tuff _....................

47. Water-laid tuff of the San Juan group along the Río Tula....

48. Volcanic conglomerate of the San Juan group . . . . . . . .

49. Silt, sand, and pumice of the Tarango formation . . . . . .

50. Contact between crossbedded sand and underlying silt, both of the Tarango formation . . . . . . . . . . . . . . . . . .

51. Contact between basalt lava flow and underlying silt stone beds, both of the Atotonilco el Grande formation ........

52. Undissected basaltic cinder cone near Zempoala, Hidalgo ....

53. Basaltic ash and lapilli of Pleistocene age in road cut southeast of Zempoala.

54. Jawbone of Mammuthus (Parelephas) columbi, found near

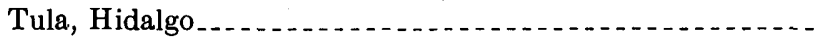

55. Caliche (white) in volcanic soil near Pachuca Hidalgo........

56. Flow structure in a small rhyolite plug near San Bartolo,

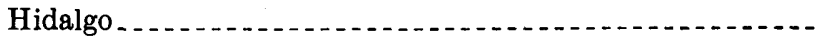


Figure 57. Fracture cleavage in marl of the Méndez formation near Los

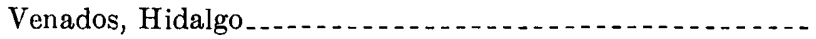

58. Eroded surface of $\mathrm{El}$ Doctor limestone, showing fracture cleavage dipping $45^{\circ}$ and nearly horizontal undulating

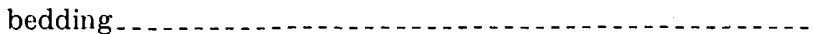

59. Ripplelike expression of fracture cleavage in shale beds of the Mexcala formation..................................

60. Coarse gravel faulted against interbedded silt, sand, and gravel of the Tarango formation.......................

61. Los Frailes, resistant pinnacles of dacite at the crest of the

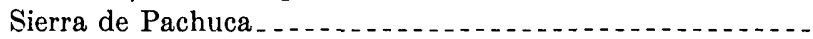

62. The terraced El Tablon surface (in shadow) and a small remnant of the higher Actopan surface. .............

63. View up the Río Tula from the rim of Cañón del Abra to the broad plain of the Ixmiquilpan valley ...............

64. Gorge of the Río Amajac, cut in El Doctor limestone in the

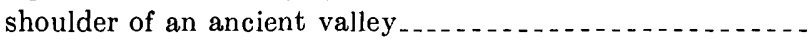

65. View southeast from Escuela Plomosas, showing gorge cut in El Doctor limestone. . . .

66. Gully cut in Recent sediments in the Ixmiquilpan valley ... .. 148

67. Valley of the Río Metztitlán, looking upstream from near Los Venados, Hidalgo, before floods of 1954 and $1955 \ldots \ldots \quad 150$

68. Valley of the Río Metztitlán, after floods of 1954 and 1955 _ 151

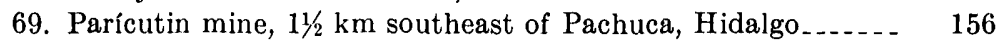

70. Loreto mill, in Pachuca ...

71. El Paje, a mine shaft in the Magdalena district......... 158

72. Arrastre used at San Clemente, Hidalgo........ 159 



\title{
GEOLOGIC INVESTIGATIONS IN MEXICO
}

\section{GEOLOGY OF SOUTH-GENTRAL HIDALGO AND NORTHEASTERN MÉXICO, MEXICO}

\author{
By Kenneth Segerstrom
}

\begin{abstract}
The area described extends from Pachuca in east-central Mexico northwestward approximately $100 \mathrm{~km}$ to Zimapán, Hidalgo, and southward to within a few tens of kilometers of Mexico City.

Folded rocks of Mesozoic age are uncomformably overlain by conglomerate of Eocene to Oligocene age and volcanic rocks of Oligocene to Pliocene age, which locally exhibit slight warping and strong fault-block tilting. Sedimentation, reexcavation, and blocking of drainage are indicated by extensive terrace deposits of late Pliocene silts and gravels. The lava flows that occupy successively lower levels of the Valley of the Rio Tula and the thermal springs that occur throughout the area indicate late Pleistocene volcanic activity. Silver, gold, lead, and zinc ore deposits in Upper Jurassic and Cretaceous marine formations and in lower and middle Tertiary nonmarine rocks are mined extensively. Nonmetallic materials of economic importance include limestone and shale for cement manufacture, kaolin and other clays, ocher, and a variety of building stones.
\end{abstract}

\section{INTRODUCTION}

\section{LOCATION}

This report covers an area extending from 40 to $145 \mathrm{~km}$ north of Mexico City and from 215 to $285 \mathrm{~km}$ west of the Gulf of Mexico. It lies mostly between lat. $19^{\circ} 50^{\prime}$ and $20^{\circ} 50^{\prime} \mathrm{N}$. and between long. $98^{\circ} 40^{\prime}$ and $99^{\circ} 24^{\prime} 30^{\prime \prime} \mathrm{W}$. A large part of central and southerm Hidalgo and the adjacent northeastern corner of the State of México are included (fig. 35). Pachuca, the capital of Hidalgo, is in the eastern part of the area. The southern edge corresponds roughly to the northern edge of the great belt of volcanoes that extends east and west across the Republic of Mexico near the 19th parallel. The central segment of a belt of mineral deposits extending from Tezuitlán, Puebla, to Xichú, Guanajuato, lies within the area here described. Most of the area is in the Mesa Central, or Mexican Highland, physiographic province, but the northeastern part lies within the Sierra Madre Oriental province. 


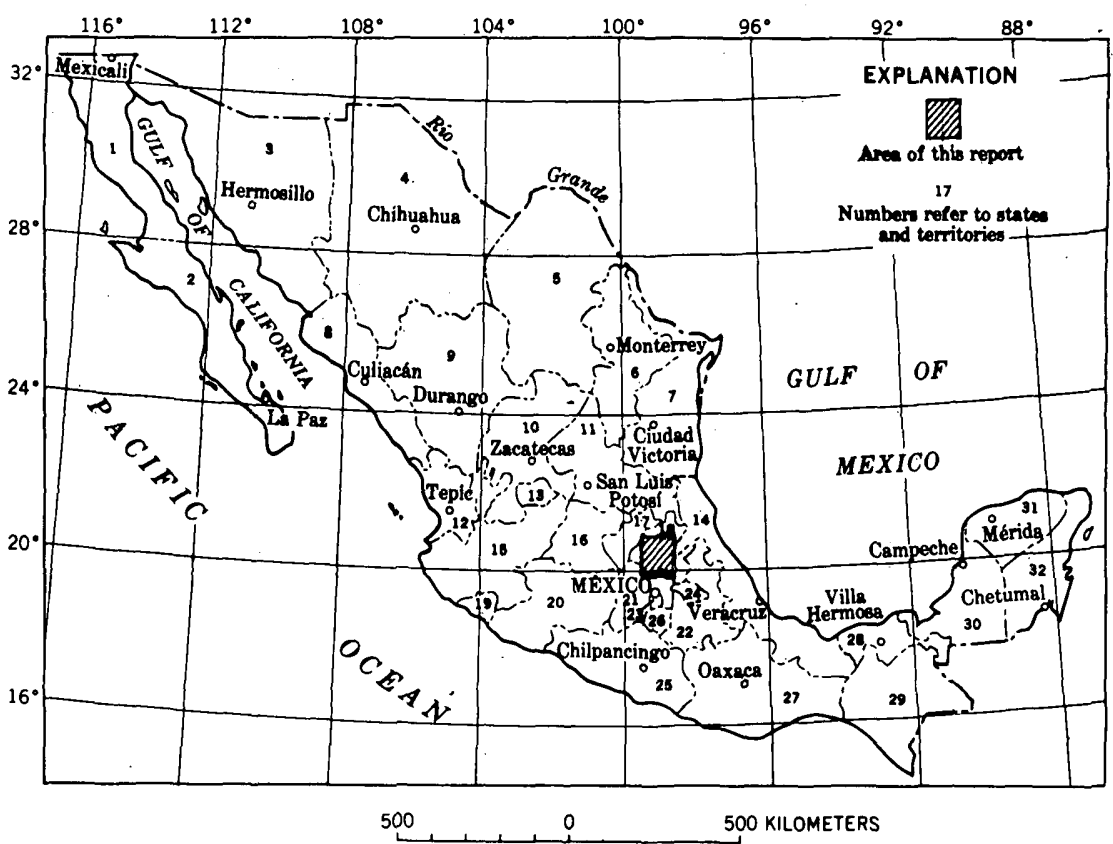

Figure 35.-Index map of Mexico showing area described in this report.

States and Territories
1. Baja California Norte
12. Nayarit
1,3. Aguascalientes
14. Veracruz
3. Sonora
15. Jalisco
16. Guanajuato
5. Coahuila
17. Querétaro
18. Hidalgo
19. Colima
7. Tamaulipas
20. Michoacán
9. Durango
21. México
10. Zacatecas
22. Puebla
23. Distrito Federal
24. Tlaxcala
25. Guerrero
26. Morelos
27. Oaxaca
28. Tabasco
29. Chiapas
30. Campeche
31. Yucatán
32. Territorio de Quintan Roo

\section{FIELDWORK AND ACKNOWLEDGMENTS}

The subject area, approximately 7,000 sq $\mathrm{km}$ in extent, was mapped geologically by the author during the period 1952-56 from oblique aerial photographs and from parts of several sheets of the Mexican Army's 1:100,000 topographic map series (pl. 3). Reconnaissance studies of parts of the area (Flores and others, 1924; Blásquez López and others, 1938) and a detailed study of the Zimapán mining district (Simons and Mapes, 1956) had been made previously. A detailed study of the Pachuca-Real del Monte mining district by A. R. Geyne and associates, including the writer, is nearly complete (1958). The present general study, including the map and sections that accompany it, portrays the regional geologic setting with more emphasis 
on stratigraphy and the sequence of geologic events and less emphasis on the mining districts than do the other reports.

The present report results from work initiated under the point 4 program of technical cooperation and completed under the auspices of the Technical Cooperation Administration of the U.S. Department of State and the Foreign Operations Administration. The author is indebted to Carl Fries, Jr., and A. J. Bodenlos, of the U.S. Geological Survey, and to B. W. Wilson, of the Shell Oil Co., for aid and counsel in the field and in the office; to A. R. Geyne, of the Compañia de Real del Monte y Pachuca, and I. W. Wilson, of the Fresnillo Co., for information about the Pachuca-Real del Monte mining districts; and to C. S. Ross of the U.S. Geological Survey, for examinations of welded tuffs. Filogonio García Cuéllar studied the limestone near Tula, Hidalgo, for the Compañía La Tolteca, and made the results available to this writer. The geologic map contains a small amount of material abstracted in part from detailed maps of Zimapán and Pachuca-Real del Monte. Fossil identifications were made by F. Bonet and Y. Eternod of Petróleos Mexicanos; W. E. Humphrey of DeGolyer and McNaughton, consultants to Petróleos Mexicanos; F. K. G. Müllerried of the Instituto Geológico de México; S. K. Fox, R. W. Imlay, R. E. Peck, L. W. Stephenson, and J. W. Wells, of the U.S. Geological Survey.

\section{GEOGRAPHY}

\section{ACCESSIBILTTX}

A network of paved highways and secondary roads covers the area, except along the northeastern edge, which is inaccessible to motorized vehicles. The chief transportation artery is National Highway 85, the Mexico City-Laredo road which was the first of three "Pan American Highways" that extend from Mexico City to the United States border. The highway from Mexico City enters the area of plate 3 at Tizayuca, Hidalgo ( $\mathrm{km} \mathrm{52)}$, and leaves it near Puerto Ing. Isidro Díaz, at $\mathrm{km} \mathrm{220.} \mathrm{The} \mathrm{cities} \mathrm{of} \mathrm{Actopan} \mathrm{and} \mathrm{Ixmiquilpan,} \mathrm{Hidalgo,}$ are at short distances from the highway, and Pachuca, Tasquillo, and Zimapán, Hidalgo, are at somewhat greater distances but are connected to Highway 85 by paved roads a few kilometers long.

Other principal towns of the area, including Tula, Progreso, and Apaxco, lie on paved roads at considerable distances from Highway 85. Two other national highways, No. 130 to Tulancingo, Hidalgo, and Tuxpan, Veracruz, and No. 105 to Atotonilco el Grande, Hidalgo, branch southeastward and northeastward, respectively, from Pachuca. Extension of Highway 105 to the gulf coast at Tampico is projected. Between Ixmiquilpan and Tasquillo a road branches off Highway 85

$6180960-62-2$ 
toward Querétaro to form a link between the Mexico City-Laredo and the Mexico City-El Paso routes. A four-lane superhighway, which will be part of the Mexico City-El Paso route, is under construction in the southwest corner of the area here described; this new road passes through Tepeji del Río, Hidalgo, and Jilotepec.

The south-central part of the area is traversed by an unimproved road that extends south from Actopan, Hidalgo, and has two prongs at the south end, one leading to Tizayuca, Hidalgo and the other to Zumpango, México. This road is passable by bus and truck from Actopan southward to Chicavasco, Hidalgo, and from Zumpango or Tizayuca northward to Santa María Ajaloapan and Mexico City, but the middle part, about $30 \mathrm{~km}$ long, is passable only by jeep. Two stretches of the road, one south of Temoaya and the other south of Hacienda de Chicavasco, follow the floors of narrow, rocky gorges for several kilometers.

A dozen or more dirt roads in the vicinity of Ixmiquilpan and Actopan, built and maintained by the Patrimonio Indígena del Valle del Mezquital, have made the north-central part of the area easily accessible.

Four jeep roads with very steep grades are of great value for approaching the remote northeastern canyon country. One of these roads leads north from the valley of Ixmiquilpan across the top of the lofty Sierra de Juárez and down the other side to Pachuca, Hidalgo, which is in a deep canyon. Another leads from the valley of Ixmiquilpan through a low gap in the mountains northeastward to Molanguillo, Hidalgo, a starting place for the descent by foot or horse to the great gorges of the Río Amajac. A third jeep road leads northwest from Santiago de Anaya, Hidalgo, across the crest of the Sierra de Actopan and down the other side to El Encino, at the head of a major tributary of the Rio Amajac. A fourth jeep road, built by a mining company in 1954 from La Estancia to Escuela Plomosas, crosses the Sierra de Actopan through high Puerto de la Rodilla.

Hundreds of kilometers of trails, not shown on the map, follow the main ridges and valleys and have connections through all the mountain passes. Every village is the hub of an extensive system of trails leading outward in all directions.

Horses are scarce in the rugged northeastern zone of deep canyons, but they are almost a necessity for reaching the Río Amajac. Arrangements for hiring animals must be made a day or more in advance, and usually separate arrangements must be made for riding saddles. It is virtually impossible to descend from the end of a road to the river and return in a single day; consequently pack animales for carrying camping supplies must also be hired. 
The area is bounded by the Pachuca-Real del Monte mining district on the east, the gorges of the Río Amajac on the northeast, the Zimapán mining district on the northwest, Tula, Hidalgo, on the west, and Zumpango, México, on the south; it straddles the boundary between the Mexican Highland and the Sierra Madre Oriental physiographic provinces. The topography of most of the area corresponds to the Mexican Highland physiographic province and consists of broad, flat-floored upland valleys, $1,600-2,400 \mathrm{~m}$ above sea level, interspersed with hills and mountain ranges rising to maximum altitudes of slightly more than $3,000 \mathrm{~m}$ above sea level. The extreme northern and northeastern parts correspond to the Sierra Madre Oriental province; they are made up of rugged mountains and narrow valleys and have a maximum relief of nearly $2,000 \mathrm{~m}$. The lowest altitude, about $950 \mathrm{~m}$ above sea level, is along the Río Amajac at the northern edge of the area of plate 3 .

The three major mountain ranges of the area are the Sierra de Pachuca, in the eastern part; the Sierra de Juárez, in the northern part; and the Sierra de Xinthé, in the western'part. The Pachuca range, together with a northern extension that is known as the Sierra de Actopan, extends from Cerro Monte Noble at the north to Real del Monte at the southeast, a distance of $45 \mathrm{~km}$, and continues southeastward for several tens of kilometers outside the area mapped. The Juárez range extends from Santuario, Hidalgo, westward to Puerto Xithá, a distance of $20 \mathrm{~km}$, and the Xinthé range extends from the vicinity of Ixmiquilpan southward nearly to Presa Endó, a distance of about $35 \mathrm{~km}$.

Parts of two extensive drainage systems, the Mexico Basin and the Río Moctezuma, are in the area. The Mexico Basin, about 100 $\mathrm{km}$ long and $60 \mathrm{~km}$ wide, lies along the Continental Divide and has no natural outlet to the sea, but it is drained artifically by two tunnels and an opencut that lead to the drainage system of the Río Moctezuma. Since 1951 a combined flow of about $9-10 \mathrm{cu}$ m per sec has passed through the tunnels, whose exits are near Tequixquiac, México, in the southern part of the area. The opencut, which is known as the Tajo de Nochistongo, carries water during the June-October rainy season, but is dry for more than half the year.

The Río Moctezuma has a drainage basin about $250 \mathrm{~km}$ wide and is one of the largest streams in eastern Mexico. Two of its principal tributaries, the Río Tula and the Río Amajac, flow through the area mapped for this report. The Río Tula drains most of the area, including a system of dissected plains or broad valleys known generally as the Valle del Mezquital. The Mezquital region is considered 
to extend roughly from Tula, Hidalgo, northeast about $50 \mathrm{~km}$ to Actopan, and thence northwest about $50 \mathrm{~km}$ to Tasquillo, but much of the country between those towns consists of hills and mountains. The Río Tula has a strong, permanent flow, of which a large part is derived from the Mexico Basin via the drainage tunnels.

The Río Amajac heads at Real del Monte, Hidalgo, along the eastern edge of the area; its largest tributary, the Río Metztitlán, heads near Tulancingo, which is outside the area mapped, about 50 $\mathrm{km}$ east-southeast of Real del Monte. The Río Amajac and Río Metztitlan drain the north slope of the Sierra de Pachuca, the east slope of the Sierra de Actopan, the broad plain of Atotonilco el Grande, and the rugged canyon country along the northeastern edge of the area; both have a strong, permanent flow, and flood periodically.

\section{CLIMATE}

Most of the area has a temperate, semiarid climate, although locally the range may be from cool and humid to hot and dry. Light freezes are common in mid-winter at altitudes above $2,000 \mathrm{~m}$. Practically all the annual rainfall occurs during the 5 months from June to October. The rainy season commonly has two peaks, in June and in September, and a lull during July and August. June is characterized by short afternoon thundershowers similar to those in the southern Rocky Mountain region of the United States. Rainfall in September and October is chiefly the effect of hurricanes in the Gulf of Mexico and the Caribbean. The duration of the rain is generally from 1 to 4 days, depending on the intensity of the hurricane.

Most of the mosture is brought from the Gulf of Mexico by east and north winds. The result is that mountains like the Sierras de Pachuca, Actopan, and Juarez have heavy rainfall on their windward slopes but cast rain shadows over adjacent country to the west and south. The winds lose most of their moisture as they pass over the high mountains, and are dry over the leeward slopes; however, these effects diminish away from the ranges. At Mineral del Chico, on the north slope of the Sierra de Pachuca, the annual mean precipitation is $1,500 \mathrm{~mm}$, but at Pachuca, on the south slope, the rainfall is only $400 \mathrm{~mm}$. At Ixmiquilpan, $15 \mathrm{~km}$ south of the base of the Sierra de Juarez, only $270 \mathrm{~mm}$ of rain falls in an average year. In the southwestern part of the area, $40-80 \mathrm{~km}$ distant from the lofty Pachuca and Juarez mountain ranges, the annual precipitation is between 500 and $600 \mathrm{~mm}$.

VEGETATION

The native vegetation varies with the climate and the slope exposure: where the precipitation is about $700 \mathrm{~mm}$ and more, there is natural forest growth on both north- and south-facing slopes; where 
the precipitation is from 500 to $700 \mathrm{~mm}$, the forest growth is largely confined to north-facing slopes; where the precipitation is less than about $500 \mathrm{~mm}$, there is little natural forest growth except along streams. The forests are chiefly of oaks, pines, firs, and madrones in the highest parts of the Sierra de Pachuca and the Sierra de Juárez, and scrub oaks, piñons, cedars, and crabapple trees at intermediate elevations in those ranges and in the highest parts of the Sierra de Xinthé. On the lower slopes in the Amajac canyon country, open stands of small palms occur. The watercourses are lined with sycamore, walnut, oak, and cottonwood trees at some places. Large cypress trees grow along the Río Tula.

On lower slopes and in uncultivated valleys throughout the area where the annual rainfall is less than about, $400 \mathrm{~mm}$, there is an abundant desert flora of mesquite, huizache, catclaw, ocotillo, lechuguilla, sotol, and cacti. Scanty stands of native grasses are also found at those places. The largest desert plants are yuccas that resemble the Joshua trees of California; they attain heights of over 10 $\mathrm{m}$, and some have trunks 1-2 $\mathrm{m}$ thick. The cacti are of a great variety and include several types of chollas, a barrel cactus, several varieties of prickly pear, and organpipe cactus, and an "old man" cactus that forms veritable forests on dry slopes bordering the Río Metztitlán. The low Cerro de Capula, $61 / 2 \mathrm{~km}$ east-northeast of Ixmiquilpan, is covered with a remarkably dense and varied growth of cacti and other desert plants, chiefly lechuguilla; at that place there is probably a greater variety of cacti than can be seen in an area of comparable size elsewhere in the region.

The native vegetative cover has been widely disturbed by man and domestic animals. Roads are lined with pepper trees and eucalypti that have been introduced from Peru and Australia, respectively. Many of the native oaks have been cut for charcoal manufacture, the pines for lumber, and the firs for the manufacture of shingles. Extensive valley areas have been cleared of desert plants by burning and plowing to make way for agriculture, and desert grasses have been largely destroyed by overgrazing.

\section{AGRICULTURE AND STOCKRAISING}

Dry-farming and the herding of goats and sheep are the chief sources of livelihood for most of the inhabitants of the area. Corn and other grains produce adequate crops without irrigation almost every year in the southern and western parts of the area, where the average annual rainfall is $500 \mathrm{~mm}$ or more, but throughout the more arid northern and northeastern parts they produce adequate crops only during years of much greater than average rainfall. The arid 
region around Ixmiquilpan is largely inhabited by Otomí Indians, who eke out a bare existence by cultivating corn and the maguey, or century plant, and by herding a few goats or sheep. The droughtresistant maguey, planted in widely spaced rows on hillsides and in valleys, is the most extensively cultivated plant of the region. The juice of the maguey is used in making a nutritious beverage called pulque, the fiber is twisted into rope and woven into cloth, and the broad leaves are used in building thatched huts.

A feature of the agricultural economy of the region is the rapidly increasing production by irrigation. In the Tula irrigation district, which extends westward nearly to Actopan, 30,000 hectares (about 74,000 acres) were being irrigated in 1956, as compared with less than 15,000 hectares in 1936. The irrigation canals are supplied from two sources: the "white waters" stored in the reservoir Presa Requena (southwest corner of the area) or the Presa Taxhimay (15 $\mathrm{km}$ southwest of Presa Requena) and the drainage tunnels near Tequixquiac. The average annual volume of "white waters" used in canals of the Tula district is about 100 million cu m, and of "black waters", 180 million cu m (for the years 1938-1953; information furnished by the Secretaría de Recursos Hidráulicos). The "black waters" are so named because of their high content of sewage from Mexico City. Other major irrigation districts of the area are those of Ixmiquilpan and of Atotonilco el Grande, which are supplied by surface flow of the Río Tula and Río Amajac, respectively.

Important crops of the three irrigation districts are alfalfa, corn, wheat, oats, rye, barley, beans, potatoes, chili, and other garden vegetables. The chief irrigated crop is alfalfa, known as the "green gold" of the region because of its high value when shipped to dairy farmers in the vicinity of Mexice City. Orchards are of minor importance : apples, pears, peaches, plums, apricots, figs, olives, and almonds are products of the Mezquital valley and the irrigated plain of Atotonilco el Grande; oranges, limes, avocados, and mangos are products of narrow strips of irrigated land along the Río Metztitlán.

\section{ARCHEOLOGY}

Tollan Xicocotitlán, one of the most important archeological localities of Mexico, lies 1/2-1 km northeast of the town of Tula, Hidalgo, in the southwestern corner of the area. Cerro Xicuco, namesake of the site, rises about $8 \mathrm{~km}$ farther to the northeast. Excavations made in 1942-43 revealed that the "Great Tollan" was the capital of the Toltec nation and the chief one of 20 tollans, or sacred cities of the Toltecs, scattered over eastern and southeastern Mexico. Another tollan was probably at the site of the present Atotonilco Tula, $14 \mathrm{~km}$ 
southeast of the "Great Tollan", and still another probably existed at Tulancingo, $30 \mathrm{~km}$ east of the area mapped. A ball court and a pyramid have been excavated at Tollan Xicocotitlán, and in 1950 the discovery of a temple partly cylindrical in form and located about $11 / 4 \mathrm{~km}$ farther north was made public. Outstanding features of these Tula ruins are great statues carved in basalt. Tollan Xicocotitlan was probably abandoned toward the end of the 12th century A.D. (Jiménez-Moreno, 1941). Several mounds of rubble mark another archeological site located $171 / 2 \mathrm{~km}$ north northeast of the present Tula.

\section{STRATIGRAPHY}

\section{JURASSIC SYSTEM}

\section{LAS TRANCAS FORMATION}

The oldest rocks exposed in southwestern Hidalgo are dark-gray slightly phyllitic calcareous shale and siltstone, impure limestone, pyritierous in part, and minor amounts of graywacke and chert (fig. 36). The name Las Trancas is proposed here for this rock unit. It is taken from Puerto de Las Trancas, near km 217 on the highway between Mexico City and Laredo, Texas, where part of the formation, including its upper contact, is well exposed in road cuts.

A thicker section of the Las Trancas, totaling about $350 \mathrm{~m}$ but not exposing the base of the formation, is well shown in the relatively inaccessible lower part of the Barranca de Tolimán about $20 \mathrm{~km}$ westnorthwest of Puerto de Las Trancas. The following lithologic succession appears in the Barranca de Tolimán, from the lowest beds exposed upward through the section : $30 \pm m$ dark-gray silty limestone, slightly phyllitic on fracture-cleavage planes, with pyrite nodules, interbeds of graywacke, and a few fossils; $270 \pm$ m dark-gray phyllitic calcareous shale and siltstone, mostly thin-bedded, but medium- to thick-bedded near the bottom and the top, which contains a few thin chert lenses and, except near the top, a few graywacke beds.

Wavy bedding and reddish stains on bedding planes characterize the top of the formation near Puerto de Las Trancas, and small concretions of calcium carbonate and veins of quartz and calcite are noted in places. In the vicinity of the Pino Alto and the El Zapote mines, about $8 \mathrm{~km}$ northwest of Puerto de Las Trancas, much graywacke and some greenish siltstone are poorly exposed; these rocks probably belong to a lower part of the section. In the vicinity of Cerro Frontón, Peñamiller, and Bernal, $60-70 \mathrm{~km}$ northwest and west of Puerto de Las Trancas, the formation thins and is absent between older rocks (conglomerate, arkose, red phyllite, and shist) and younger limestone. The formation is poorly resistant to erosion and crops out mainly in topographic lows. 


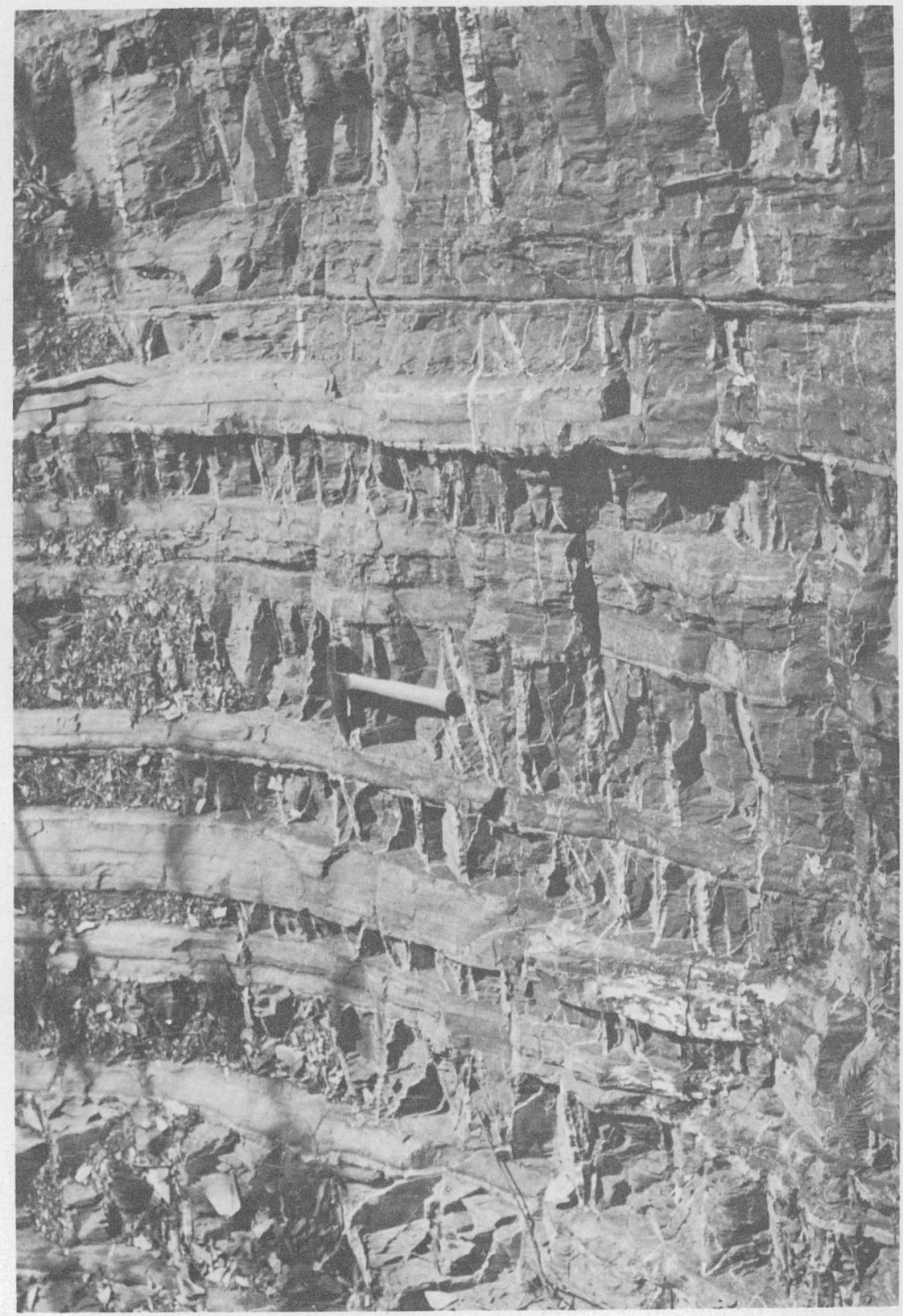

FIgURE 36.- Impure limestone and calcareous shale of the Las Trancas formation near Adjuntas de San Pablo, $15 \mathrm{~km}$ east-northeast of Zimapán, Hidalgo. 
Ammonites were collected by Carl Fries, Jr., Pedro Hernández, B. W. Wilson, and the author in July 1954 from a locality a few hundred meters east of the highway at Puerto de Las Trancas; these belong for the most part to the genus Parodontoceras, of middle to late Portlandian age. Associated fragments are questionably referred to the genera Protancyloceras, Corongoceras, and Spiticeras (R. W. Imlay, oral communication, 1953). Fossils were also collected by Fries, W. E. Humphrey, M. Maldonado-Keordell, and the author in May 1954 from the lower part of the Barranca de Tolimán; these include the ammonite Mazapitites, of late Kimmeridgian age (Humphrey, oral communication), and a lytocerid ammonite and an aptycus (Imlay and John Reeside, oral communication, 1953), all of the same age as that of the lithologically different Tamán formation (see fig. 37 ), whose type locality is about $75 \mathrm{~km}$ northwest of Puerto de Las Trancas. The uppermost 100-200 $\mathrm{m}$ of the Las Trancas formation appear to be unfossiliferous.

\section{CRETACEOUS SYSTEM}

\section{SANTUARIO FORMATION}

Overlying the Las Trancas formation conformably, at distances ranging from 10 to $20 \mathrm{~km}$ east and southeast of Puerto de Las Trancas, are dark gray limestone, calcarenite, phyllitic shale, and graywacke. These rocks differ from those of the Las Trancas formation in their higher total content of calcium carbonate, in the presence of thickbedded calcarenite and large limestone concretions, and in the absence of chert. The name Santuario is here proposed for this unit, after the village of Santuario, which is accessible by a gravel road from Ixmiquilpan, $22 \mathrm{~km}$ to the southwest.

At a distance ranging from 1 to $2 \frac{1}{2} \mathrm{~km}$ north-northeast of Santuario, the following lithologic succession was noted : $75 \pm \mathrm{m}$ dark-gray thin-bedded graywacke, shale, and an occasional limestone bed containing fossils; $50 \pm \mathrm{m}$ dark-gray thin- to medium-bedded limestone and abundant shale partings; $10 \pm \mathrm{m}$ shale or phyllite containing rusty-weathering limestone concretions as much as $1 \mathrm{~m}$ long and $0.5 \mathrm{~m}$ thick $50 \mathrm{~m} \pm$ dark-gray impure limestone and phyllite; $5 \mathrm{~m}$ thickbedded calcarenite; $15 \mathrm{~m}$ calcareous phyllite interbedded with calcarenite; and $75 \mathrm{~m}$ dark-gray fetid limestone in beds $25-75 \mathrm{~cm}$ thick, to the contact with chert-bearing limestone of the El Doctor formation. The formation apparently is missing near Puerto de Las Trancas and to the west of that place, where the Las Trancas formation is overlain directly by the El Doctor formation. The Santuario is poorly resistant to erosion.

$6180960-62-3$ 


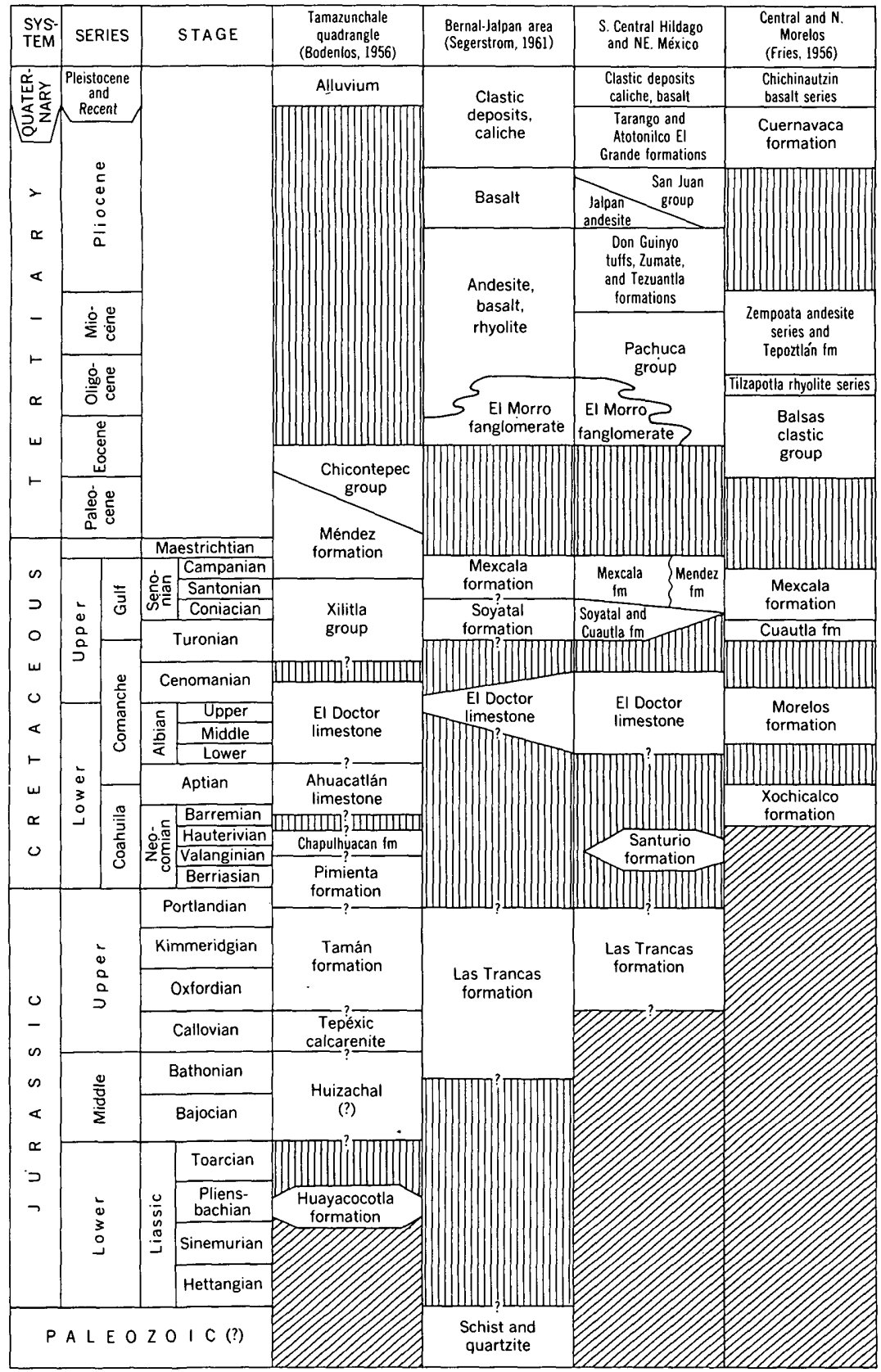

FIGURE 37.-Stratigraphic correlation of geologic units in parts of Mexico. 
Ammonites collected by the author in March 1955 about $1 \mathrm{~km}$ north of the village of Santuario probably belong to the genera Olcostephanus and either Acanthodiscus or Distoloceras, of Valanginian or early Hauterivian age (Imlay, oral communication, 1953). Humphrey believes that the strata from which they came are possibly coastal facies of Neocomian age. The Santuario formation is correlative with the Taraises formation and with the upper part of the Pimienta formation of northern and east-central Mexico. Both Olcostephanus and Distoloceras occur in the Taraises formation (Rogers and others, 1956). Microfossils were not found in the formation, although limestone chips from about ten localities were examined.

\section{FL DOCTOR LIMESTONE}

Relatively pure limestone of varied texture, containing at some places chert lenses, dolomite interbeds, and shale partings, overlies the Santuario formation in the eastern part of the area and directly overlie the Las Trancas formation in the western part. No angular unconformity with the underlying rocks was recognized. This predominantly limestone unit was named El Doctor (Wilson and others, 1955), after the village of El Doctor, Querétaro, located about 25 $\mathrm{km}$ northwest of Zimapá. The type locality is on the northeast flank of a great limestone bank where four facies of the formation have been described and mapped: a shallow-water biostrome facies, a conglomerate facies, a facies of thick limestone beds with chert nodules, and a deep-water facies of thin-bedded limestone with abundant thin chert lenses.

A shallow-water biostrome facies of the El Doctor limestone is shown on plate 3. The other facies, however, are ill defined in the area and so were not mapped separately. For $30 \mathrm{~km}$ northeast and southeast of Ixmiquilpan, the hills that rise above deposits of Cenozoic age are composed almost entirely of light- to medium-gray thick-bedded or massive limestone (the El Doctor) with numerous biostromes and without chert. Farther northeast of Ixmiquilpan, medium- to thin-bedded limestone with chert nodules and lenses is abundant. Farther southeast and south, numerous medium to thick beds of calcarenite, calcirudite, and dolomite crop out, although their total volume is much less than that of the predominant medium- to fine-grained limestone. These beds in the Tula-Apaxco area south of Ixmiquilpan are similar in lithology and age to the Morelos formation, which was mapped south of Mexico City and described by Fries (1956).

In general, the chert-bearing limestone is a much darker gray than the limestone without chert. A few beds of limestone breccia are 
distributed irregularly through the section. One of these beds, cropping out a short distance northeast of Zimapán, contains unoriented slabs, some of which are ten times as long as they are wide.

A bank facies consisting of a mass of light-hued chertless biostromebearing limestone lies to the east and south of Ixmiquilpan. This northward-striking mass is $47 \mathrm{~km}$ long and has a maximum width of about $20 \mathrm{~km}$. The thickness of the facies is probably $750-900 \mathrm{~m}$, whereas the El Doctor limestone thins to $100-200 \mathrm{~m}$ in the Sierra de Juárez, $16 \mathrm{~km}$ north of Ixmiquilpan. Farther to the northwest and east, the El Doctor limestone attains greater thicknesses, even where biostromes are rare or absent. Another limestone bank at Jacala (Bodenlos, 1956) crops out at the north end of the area mapped. A small bank near Tonaltongo crops out about $5 \mathrm{~km}$ northeast of the Ixmiquilpan bank.

The El Doctor limestone is highly resistant to erosion and tends to form cliffs at the youthful stage of the erosion cycle (fig. 38) and high rounded mountains at the mature stage.

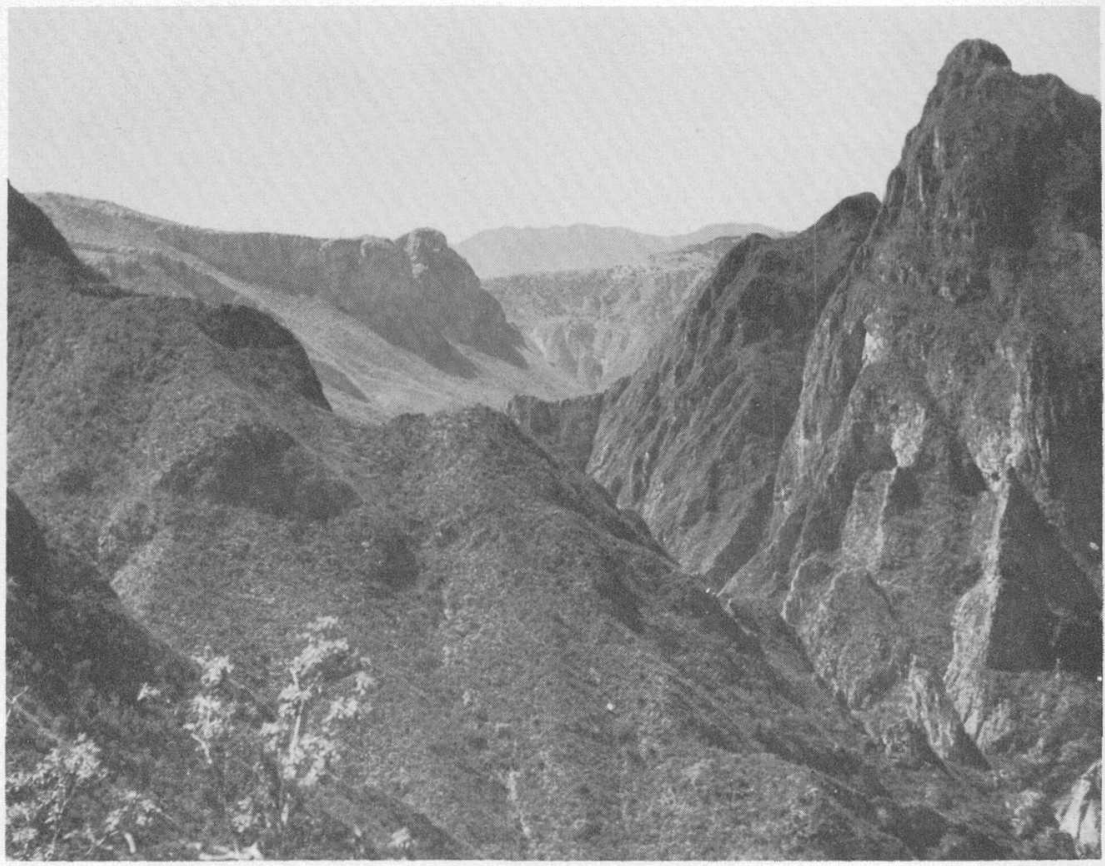

Figure 38.-Cliffs of El Doctor limestone along the gorge of the Río de Tonaltongo, $33 \mathrm{~km}$ east-northeast of Ixmiquilpan. 
Rudistids and gastropods are the most abundant macrofossils in the bank facies, although some corals, oysters, pelecypods, and echinoids are associated with them in places. Most of the rudistids belong to the genera Caprinuloidea and Toucasia, but Radiolites, Eoradiolites, and Monopleura occur also (Müllerried, 1939). The gastropods are principally of the genera Nerinea and Actaeonella. Oysters include the genera Exogyra and Gryphaea; other pelecypods include Chondrodonta, Pinna, and Neithea. The fauna are commonly fragmental. Some of the fossils, particularly Toucasia and Nerinea, are found in thick-bedded limestone outside the bank areas, where they are fragmental and occur in breccia. Small, open-coiled ammonites occur on a few of the bedding planes of nonbank El Doctor limestone, where the limestone is commonly thin bedded and contains abundant chert lenses, these ammonities include some of the types at the base of the formation near Higuerillas, Querétaro.

Microfossils, particularly species of the family Miliolidae, are very abundant in some of the fine-grained beds of the bank facies. They occur more sparingly in medium- and thick-bedded limestone outside the bank areas. Many of the miliolids of the genera Nummuloculina, Quinqueloculina, Triloculina, Massilina, and others are visible with a hand lens.

The foregoing faunal assemblage indicates that the El Doctor limestone ranges in age from middle Albian to early Cenomanian. The chert-free, biostrome-bearing facies somewhat resembles the UrgonianEl Abra limestone of the Tampico Embayment to the northeast (Bonet, 1952), whereas the formation as a whole more closely resembles the Morelos formation to the south (Fries, 1956). Of hundreds of fossil localities seen, only a few are shown on the map; the most notable of these Grutas de Xoxafí, $22 \mathrm{~km}$ southeast of Ixmiquilpan.

\section{CUAUTLA FORMATION}

Beds of two distinct types overlie the El Doctor limestone disconformably. These beds are assigned to the Cuautla and Soyatal formations, which are considered to be of the same age, in part, but which represent different facies. The Cuautla formation is exposed on Cerro Blanco (near Apaxco, México), on Cerro de la Palma (near Tula), and in an area $3-4 \mathrm{~km}$ northwest of San Lucas, Hidalgo ( $\mathrm{pl}$. 3 ). It is named after the town of Cuautla, Morelos, $134 \mathrm{~km}$ southsoutheast of Cerro Blanco, where its outcrop area is much more extensive than farther north and where it attains a maximum thickness of $750 \mathrm{~m}$ (Fries, 1956). Practically all the intervening area is covered by sediments of the Mexico Basin and by the volcanic rocks of the high mountain range south of Mexico City. 
The formation consists of thick limestone beds, mostly calcarenitic, and contains numerous biostromes ranging in thickness from $1 / 2$ to $2 \mathrm{~m}$. Nodules and short lenses of chert not exceeding $6 \mathrm{~cm}$ in thickness are sparsely distributed through the limestone. A conglomerate bed not over $11 / 2 \mathrm{~m}$ thick, containing pebbles and cobbles of limestone, lies at the bottom of the formation on Cerro de la Palma. The area between Cerro Blanco, Cerro de la Palma, and San Lucas (not to be confused with another San Lucas, which lies to the southwest of Tula) is entirely underlain by volcanic rocks and terrestrial sediments.

About 100-200 $\mathrm{m}$ of the Cuautla formation are exposed above the El Doctor limestone on Cerro Blanco and Cerro de la Palma. Both top and bottom of the Cuautla formation are exposed, although poorly, northwest of San Lucas. There the formation probably attains a maximum thickness of $300 \mathrm{~m}$, but the outcrops are so covered with caliche that it is difficult, if not impossible, to measure the section accurately. The formation disappears abruptly $5 \mathrm{~km}$ west of San Lucas, where the Mexcala formation directly overlies the El Doctor limestone. The Cuautla formation was deposited in a relatively narrow zone and lenses out both east and west of the northwesttrending outcrop belt.

The biostromes at all three localities contain abundant individuals of Hippurites mexicana Bárcena, of late Turonian age (fig. 39), as well

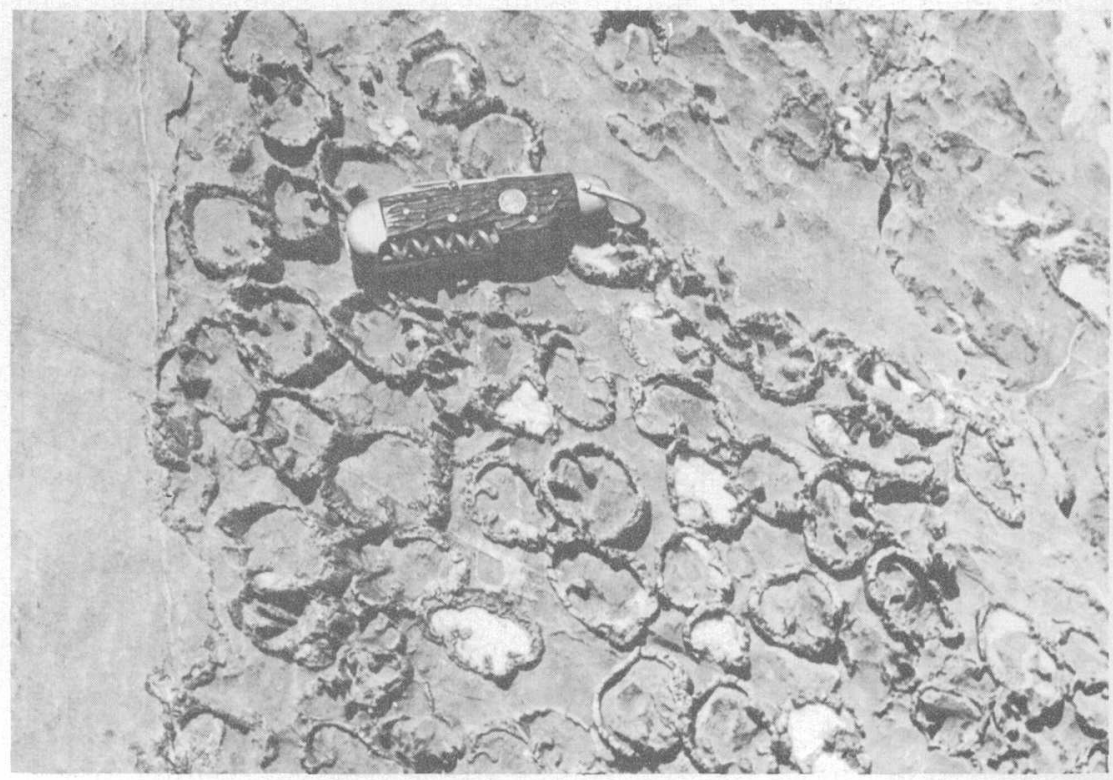

Figure 39.-The rudistid Hippurites mexicana Bárcena on the weathered surface of a limestone bed of the Cuautla formation near San Lucas, about $24 \mathrm{~km}$ west of Ixmiquilpan, Hidalgo. 
as remains of other rudistid genera such as Toucasia, Radiolites, and Durania, and of the gastropod genus Actaeonella. Most of the rudistids are well silicified.

H. mexicana Bárcena was reported from Barranca Seca, a few kilometers northwest of Zimapán, and from the E1 Doctor area farther northwest (Bárcena, 1875), but despite diligent search, Hippuritesbearing limestone has not been found in place by later geologists who have made detailed studies at both places; one piece of limestone float containing $H$. mexicana and apparently eroded from conglomerate of early Tertiary age was found in the El Doctor area in 1954 (B. W. Wilson, oral communication). Inasmuch as El Doctor, Querétaro, lines up fairly well with Cerro Blanco and the locality near San Lueas, the Cuautla formation likely extended that far north in early Tertiary time.

\section{SOYATAL FORMATION}

Medium- to thin-bedded dark-gray impure limestone, with interbedded shale and without chert (fig. 40), represents a change in facies

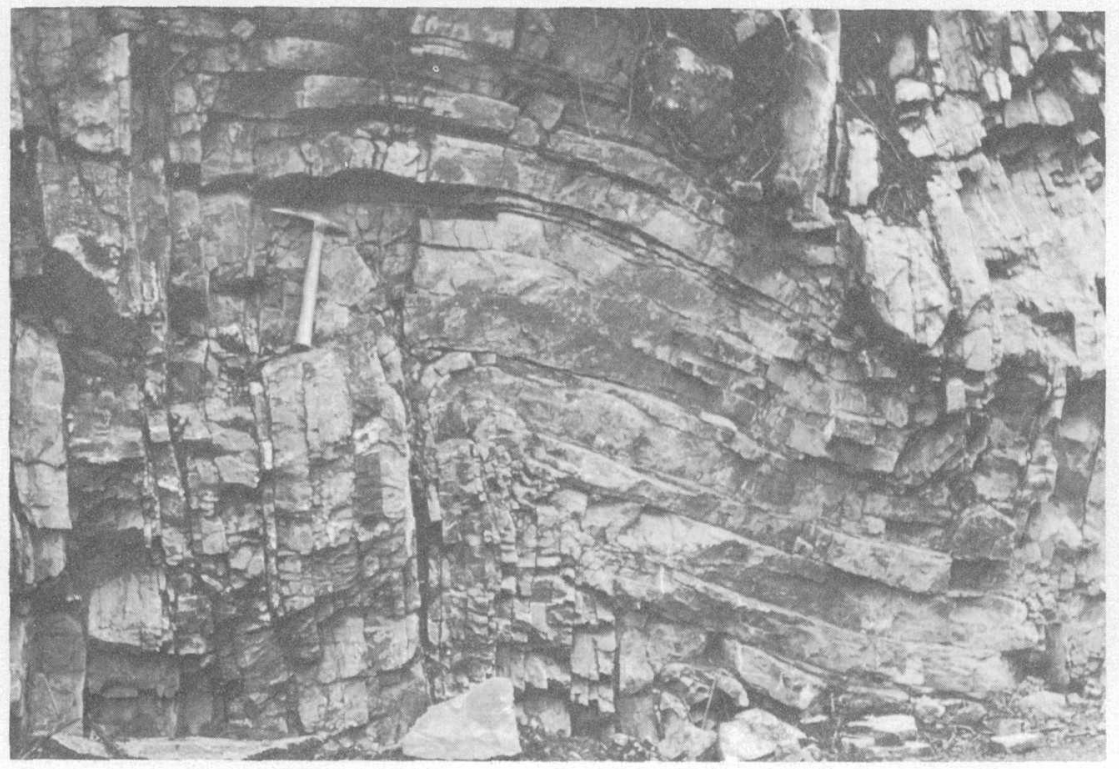

Figure 40.-Folded limestone beds and shale partings of the Soyatal formation in a road cut near La Providencia, $7 \mathrm{~km}$ north of Cardonal, Hidalgo. View is toward the south; the fold is overturned toward the east.

from the Cuautla formation in the northern and central parts of the area, but it seems to be missing in the eastern part. This rock unit is known as the Soyatal formation because of the good exposures near the small antimony-mining camp of Soyatal, Querétaro, $48 \mathrm{~km}$ north- 
west of Zimapán. In the original published description (White, 1948) the formation was left unnamed, but it was later defined and named the Soyatal formation by Wilson and others (1955). At the type locality the formation is the lower part of the upper of three units mapped by White (1948), and it exhibits the following lithologic succession : $1-40 \mathrm{~m}$ of limestone conglomerate and massive limestone, followed by $50-75 \mathrm{~m}$ of alternating limestone and calcareous shale; the proportion of shale beds increases upward. In the El Doctor mining district, about midway between Soyatal and Zimapán, the lower part of the Soyatal formation consists of well-bedded darkgray fine-grained limestone in beds $10-20 \mathrm{~cm}$ thick with thin partings of reddish shale; the upper part consists of limestone interbedded with argillaceous limestone and calcareous shale $5-10 \mathrm{~cm}$ thick. The maximum thickness of the formation here is $150 \mathrm{~m}$ (Wilson and others, 1955).

A good exposure of the lower beds is in a large arroyo east of the village of Xuchitlán, Hidalgo, and about $13 \mathrm{~km}$ southeast of Txmiquilpan. At that place medium-bedded dark-gray microlaminated argillaceous limestone contains abundant reddish shale interbeds and an occasional purer limestone bed. The upper beds are well exposed in a deep arroyo south of Defay, Hidalgo, approximately $16 \mathrm{~km}$ northnortheast of Ixmiquilpan. About two-thirds of the volume of rock there is yellow-weathering gray 'calcareous shale, and one-third is black limestone, microlaminated in part. The Soyatal formation tends to form topographic lows, its thickness ranges from 0 to $300 \mathrm{~m}$.

The formation is sparsely fossiliferous for the most part, but the pelecypod Inoceramus labiatus Schlotheim was found by T. Paredes and F. K. G. Müllerried on Cerro Cuesta de México $6 \mathrm{~km}$ south of Ixmiquilpan, and by the author on the road to San Clemente and near La Providencia, 18 and $24 \mathrm{~km}$, respectively, north-northeast of Ixmiquilpan. The Inoceramus indicates a Turonian age (L. W. Stephenson, oral communication, 1953). Several poorly preserved specimens of the pelecypod Didymotis? collected by the author at the Xuchitlan locality described above indicate that the age of the Soyatal formation may extend into early Coniacian time. Three specias of Foraminifera of the genus Globotruncana were found in shale collected by the author at the Xuchitlán locality, but these indicate only the Late Cretaceous age and do not restrict the age to a particular stage; the ranges of all three species are considered to extend as low as Turonian (Yvette Eternod, oral communication). The rudistid Hippurites Ilamasi n. sp. was reported from the north base of Cerro Cuesta de México in a limestone bed of the Soyatal formation. The age of $H$. llamasi was given as middle Senonian (Santonian) by Müllerried (1948), but it is almost certainly older. 
The Soyatal formation is roughly equivalent in age (a) to the Agua Nueva formation of east-central and northeast Mexico and the lower part of the San Felipe formation (Turonian-Coniacian) of the Tampico Embayment (Imlay, 1944), (b) to most of the Xilitla group of the front ranges of the Sierra Madre Oriental (Bodenlos, 1956), and (c) to the Cuautla formation (upper Turonian) and the lowermost part of the Mexcala formation (lower Coniacian-Campanian(?)) in the States of Morelos and Guerrero (Fries, 1956) (fig. 37).

\section{MEXCALA AND MÉNDEZ FORMATIONS}

Calcareous siltstone and claystone, or marl, interbedded with sandstone or graywacke and thin limestone strata, overlie the Cuautla and Soyatal formations in the western part of the area and are in direct contact with the underlying El Doctor limestone in the eastern part, without apparent angular unconformity. A facies change from the marly Méndez (Tampico Embayment) to the relatively sandy Mexcala formation (Morelos-Guerrero) probably exists in the area, although it is so gradual that neither facies can be mapped separately. The lower part of the Mexcala formation may in some areas be equivalent in age to the upper part of the Soyatal formation; it represents a facies change to more clastic material without limestone interbeds.

In the El Doctor mining district northwest of Zimapán, the Mexcala formation consists of thick-bedded dark-gray carbonaceous shale interbedded with thinner layers of limestone, calcareous shale, and graywacke (Wilson and others, 1955). Near the Río Jilotepec and its tributaries, $8 \mathrm{~km}$ south of Tula, the Mexcala formation consists of gray siltstone in beds $5-15 \mathrm{~cm}$ thick interbedded with gray shale as much as 4 or $5 \mathrm{~cm}$ thick, a few greenish graywacke beds as much as 40 $\mathrm{cm}$ thick, and sparse thin strata made up of pyrite concretions. In the vicinity of $\mathrm{El}$ Manchado, Hidalgo, about $25 \mathrm{~km}$ east-northeast of Ixmiquilpan, fossil mud cracks appear in claystone beds of the Méndez (or Mexcala?) formation. In general, the beds are thicker and somewhat more calcareous in the eastern than in the western part of the area. Along the Río Metztitlán near La Paila, in the extreme northeast corner of the area, for example, calcareous claystone (marl) attains bedding thicknesses of $1 \mathrm{~m}$ or more in the lower part of the section. These beds resemble beds of the Méndez formation, whereas those of the western part of the area resemble beds of the Mexcala formation.

The Mexcala and Méndez formations are poorly resistant to erosion (fig. 41) and tend to form strike valleys threaded by subsequent streams. Splintery fracture (fig. 42) and yellow-weathering surfaces are strongly characteristic. The formations have a combined 


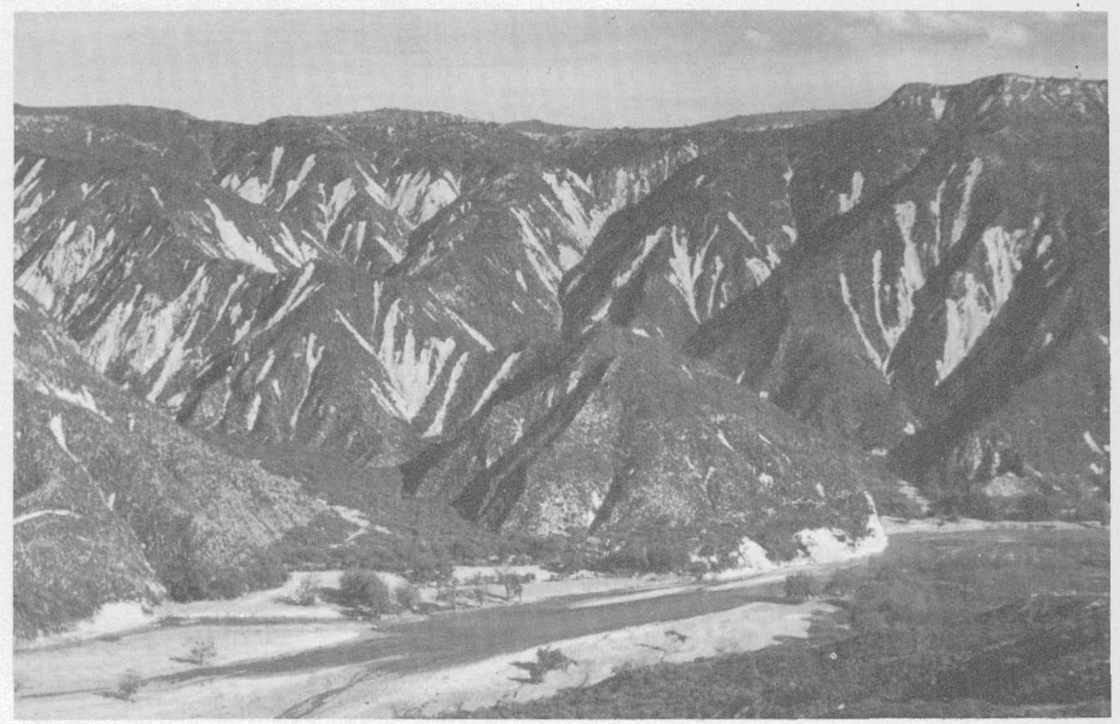

FIgURe 41.-Landslide scars (gray slopes) in the poorly resistant Méndez formation, $11 / 2 \mathrm{~km}$ southeast of Los Venados, Hidalgo.

thickness of probably $600-1,000 \mathrm{~m}$ throughout the southwestern part of the State of Hidalgo.

Macrofossils are lacking in all but the lowermost beds of the two units. Ammonites of the genera Nowakites and Texanites, collected by the author at Dedhó $6 \mathrm{~km}$ west-northwest of Zimapán, indicate that the Mexcala formation at that place includes beds of Coniacian, Santonian, and Campanian age (R. W. Imlay, written communication, 1953). Microfossils are abundant in some strata of both formations. The chief genus is Globotruncana, but Globigerina, Gümbelina, Planoglobulina, Baculogypsina, and other genera have also been identified in shale from the area. An assemblage of Foraminifera, collected from Méndez shale near its contact with El Doctor limestone $7 \mathrm{~km}$ northwest of Atotonilco el Grande, Hidalgo, by Carl Fries, Jr., and the author, contained species whose ages range from Coniacian to Maestrichtian (A. R. Loeblich, Jr., oral communication, 1953), indicates the difficulty in determining a precise age. Globotruncana, visible under a hand lens, fairly pepper yellow-weathering marl near the road fork to Metztitlán and Zacualtipán $21 \mathrm{~km}$ north of Atotonilco el Grande.

The age of the Mexcala formation at its type locality is lower Coniacian to possibly Maestrichtian (Fries, 1956). The lower part of the unit may be somewhat younger in southwestern Hidalgo. The age of the Méndez formation in the Tampico Embayment is Campanian 


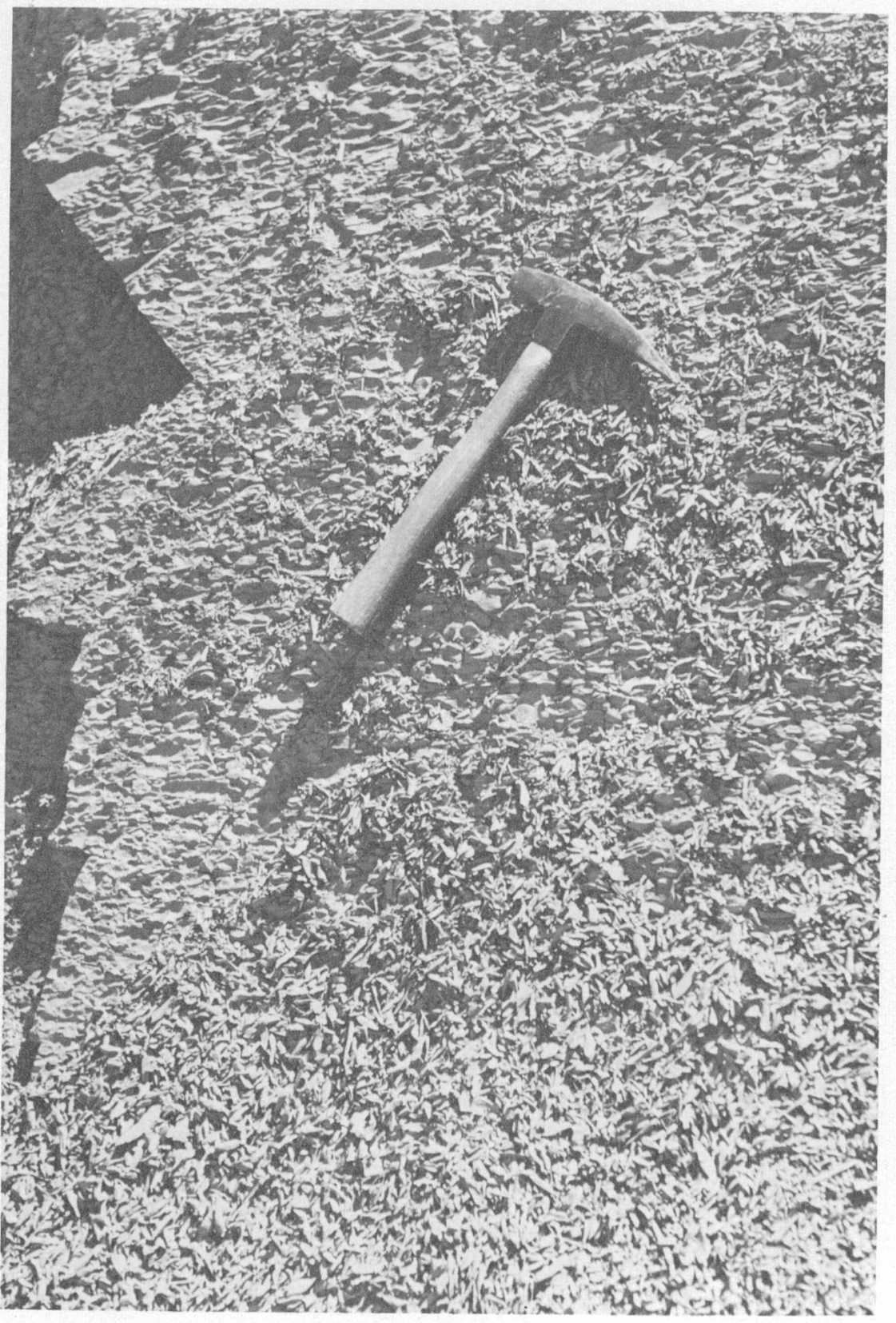

Frgure 42.- Splintery fracture of the Mexcala or Méndez formation near El Manchado, Hidalgo. 
to Maestrichtian; hence, the lower part in the southern part of Hidalgo is surely older.

\section{TERTIARY SYSTEMI}

\section{EL MORRO FANGLOMERATE}

Well-indurated coarse limestone conglomerate with a reddish-gray matrix overlies marine beds in the Zimapán area with a very angular unconformity. The limestone cobbles and boulders appear to have been derived mostly, if not entirely, from the Soyatal formation in that area. Andesite and basalt lava and tuff are locally interbedded with the conglomerate from a few meters above its base to its top. This formation has been called the El Morro fanglomerate, after Cerro del Morro, which is $6 \mathrm{~km}$ northwest of Zimapán. The rock unit is of terrestrial origin and probably resulted from the rapid shedding of sediments from a steep-bordered highland into a subsiding basin (Simons and Mapes, 1956).

Near Santa María Ajoloapan, México, about $36 \mathrm{~km}$ southwest of Pachuca, Hidalgo, similar limestone conglomerate is interbedded with siltstone containing andesitic material. Well-indurated conglomerate without volcanic constituents occurs in small outcrops both northwest and southwest of Puerto de Las Trancas, on the northwest flank of the Sierra de Juárez, along the east base of the Sierra de Xinthe (south of Panales, and south of Hacienda de Xinthé), on Cerro Tunititlán (north of Mixquiahuala), west of Puerto de Los Pastores (Xuchitlán, Hidalgo), on the south side of Cerro Peña Colorado (north of Tepatepec), in the canyons of the Río Metztitlán (near La Paila, fig. 43) and the Río Amajac (near Sänta María Amajac and near San Juan Tlatepexi). At the Cerro Tunititlán, Santa María Ajoloapan, and Santa María Amajac localities the reddish color in the matrix is absent. Shale fragments, possibly derived from the Mexcala formation, are associated with the predominantly limestone constituents at several localities, including Cerro Tunititlán, where platy blocks of shale or siltstone attain lengths of as much as $50 \mathrm{~cm}$, and subrounded limestone boulders attain a maximum diameter of $1 \mathrm{~m}$. In general, sorting is poor, tabular fragments are unoriented, and bedding is ill defined, although the sandstone lenses in the red conglomerate near Hacienda de Xinthé are well crossbedded.

Limestone cobbles and boulders must have been transported several kilometers before deposition at some localities; at Cerro Tunititlán and near Hacienda de Xinthé, for example, the conglomerate consists mostly of coarse El Doctor limestone, yet the nearest outcrops of El Doctor beds occur at distances of 4 and $7 \mathrm{~km}$, respectively. The coarsest limestone fragments near Xinthé are $20 \mathrm{~cm}$ in diameter and are 


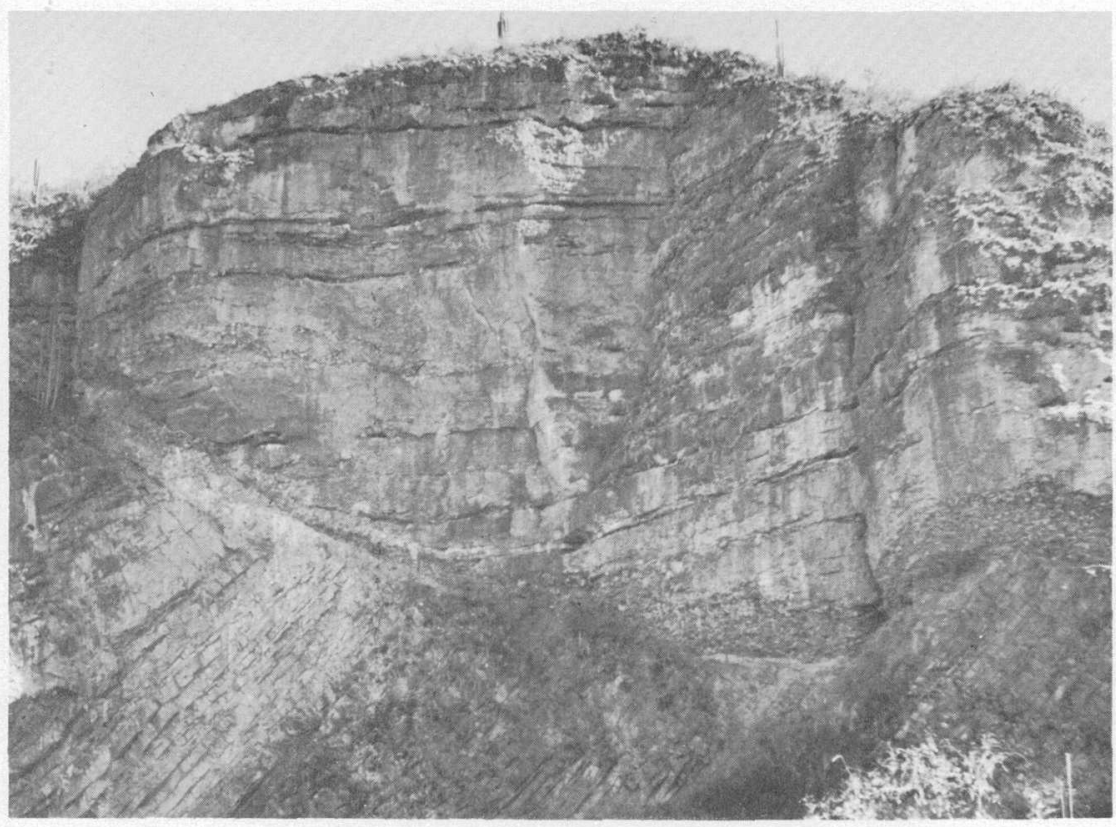

Figure 43. - Well-indurated conglomerate of the El Morro fanglomerate lying uncomformably on the El Doctor limestone near La Paila, Hidalgo.

well rounded, whereas those at Tunititlán are five times as thick and are subrounded, thus, the structure of the latter indicates shorter transport.

The conglomerate attains a maximum thickness of $400 \mathrm{~m}$ at Zimapán (Simons and Mapes, 1956) and 100 m near Santa María Ajoloapan but is probably only a few tens of meters thick at the other localities. It is strongly resistant to erosion and is therefore a cliffformer.

No fossils have been found in the El Morro beds at any place mentioned above, but the occurrence of limestone fragments and the relation to other rocks suggest that the group is equivalent in age and depositional history to the so-called red conglomerate of Guanajuato (Edwards, 1955), whose basal part is no younger than earliest Oligocene and no older than late Eocene (Fries and others, 1955). The age of the red conglomerate is of great significance in deciphering the geologic history of southern Hidalgo for two reasons: (a) the red conglomerate is younger than the time of tight folding, and (b) its presence indicates marine withdrawal before late Eocene time. In the States of Morelos and Guerrero, south of Mexico City, the red conglomerate is included in the Balsas clastic group (Fries, 1956). 


\section{PACHUCA GROUP}

Volcanic rocks ranging in composition from basalt to rhyolite overlie the El Morro in places without a marked unconformity. They overlie older rocks, however, with a pronounced unconformity at many places in southwestern Hidalgo and northeastern México. The best known and probably the thickest sequence of these rocks is in the Sierra de Pachuca. The name Pachuca is here proposed for the complexly faulted group of the intruded, hydrothermally altered, and mineralized volcanic rocks that occur under rhyolite flows in the Sierra de Pachuca, and for volcanic rocks of equivalent stratigraphic position, with or without a capping of rhyolite, in other mountain ranges of the area.

Within the Pachuca-Real del Monte mining district, where the group has been mapped in detail, the rocks have been subdivided into seven formations composed principally of andesite and one overlying rhyolite formation. The formations are defined on the basis of lenticular but fairly continuous tuff beds in the predominant-andesiterhyolite flow series; a given tuff, together with the flows above it to the base of the next higher tuff member, is generally defined as a formation. The sum of maximum individual thicknesses of the formations (excluding the lowest one, whose bottom is not exposed even in the deepest mine workings) is about $2,000 \mathrm{~m}$, although less than half that thickness can be measured at any one place, owing to lensing of the rock units.

Disconformities within the group are so variable in magnitude that one of the youngest formations may lie directly upon one of the oldest units in any one locality, or directly upon each of four or five intervening formations in an equal number of other localities.

Rhyolite flows above the andesitic formations in the Sierra de Pachuca are included in a formation called the Cerezo (A. R. Geyne, oral communication, 1956). A strongly developed platy flow structure and a spherulitic texture are common. Erosion has reduced the extent and thickness of the formation.

In the Sierra de Juárez, a thickness of $1,000 \mathrm{~m}$ or more of rhyolite and andesite crops out; in the Sierra de Actopan, $500 \mathrm{~m}$ of basalt, andesite, and rhyolite occur; and in the Sierra de Xinthe there are $600-700 \mathrm{~m}$ of andesite. Thinner sequences are exposed in outlying mountain ranges and hills away from the large eruptive centers, as, for example, in Cerro de Las Espinas, about $7 \mathrm{~km}$ northwest of Zimapán, and in Cero del Picacho, just north of Santa María Ajoloapan. The Las Espinas volcanic rocks (Simons and Mapes, 1956) range in composition from basalt to quartz latite but are chiefly 
andesitic. They conformably overlie and are interfingered with the upper part of the El Morro fanglomerate and attain a maximum measured thickness of $375 \mathrm{~m}$. The volcanic pile in Cerro del Picacho resembles that of the Sierra de Pachuca qualitatively but not quantitatively, for the andesite at Cerro.del Picacho has a total thickness of less than $150 \mathrm{~m}$.

Platy flow structure, which developed during the time of consolidation and which includes planar parallelism of phenocrysts, compositional layers, inclusions, and other constituents is very common in the Pachua group. Flow structure is usually parallel to the top and bottom of the andesite and basalt flows, but its attitude may be as steep as $90^{\circ}$ away from the top and bottom of rhyolite flows.

Clastic rocks in the Pachua group range from fine-grained tuff to coarse tuff-breccia. Conglomerate, representing erosion of preexisting volcanic surfaces, transportation, and deposition, is also present at several horizons within the group. Tuff is much less resistant to weathering and erosion than the flows with which it is interbedded, and on a hillside it tends to form oxidized and leached zones of "soft" topography between outcrops of lava.

Welded tuff appears to be present in both the lower and the upper parts of the Pachua group, at least in the northwestern part of the area mapped. A massive dense rhyolitic rock in the predominantly basaltic lower part at $\mathrm{km} 200$ on the Pan American Highway has clean-cut welded shards of microscopic size. Well-foliated rhyolite from a road cut in the upper part of the Pachua group near $\mathrm{km} 187$ exhibits a linear distribution of small lenslike areas of secondary quartz, which may have formed in the pores of a pumice. This rock has a ghostlike structure that looks like welded tuff (C. S. Ross, oral communication, 1953).

Much fragmental rock in the Pachua group does not seem to be pyroclastic, for at some places it has flow layering in the matrix and unbrecciated "cores"; nor is it cataclastic, for there are no faults nearby. This rock is flow breccia (fig. 44), which shows a primary structure rather than a structure resulting from later deformation. Flows of the Sirrea de Pachua exhibit extensive brecciation, but this phenomenon is less common in other great eruptive centers of the region (Sierra de Juárez, Sierra de Xinthé) and is relatively rare in outlying volcanic areas.

Lacustrine deposits occur locally in the Pachua group. The following section was observed at Cuesta del Chiflón on the south side of the Río Amajac and just west of the abandoned hacienda of San Juan, or $14 \mathrm{~km}$ north-northeast of Pachua : 
Early Tertiary:

Top of hill.

Meters

(approximate)

Andesite flows

Limestone

Andesite flow

Limestone.

Andesite flow

Limestone, thin- to medium-bedded, cream-colored, fine-grained; lenses and interbeds of black chert as much as $10 \mathrm{~cm}$ thick. Ostracodes and remains of fossil plants occur in beds totaling about $4 \mathrm{~m}$ in thickness near top of unit

Andesite flows and flow breccia.

Andesite tuff

Andesite flows and flow breccia

Bed of the Río Amajac; $1,950 \mathrm{~m}$ above sea level.

In the vicinity of Tezahuapa, about $2 \mathrm{~km}$ east of Cuesta del Chiflón, the limestone is underlain by lacustrine shale. Both the limestone and the shale contain chert.

The above section has been previously described by Wittich (1919, p. 410), who incorrectly considered the limestone to be of Cretaceous age and the andesite in this section to be therefore also of Cretaceous age.

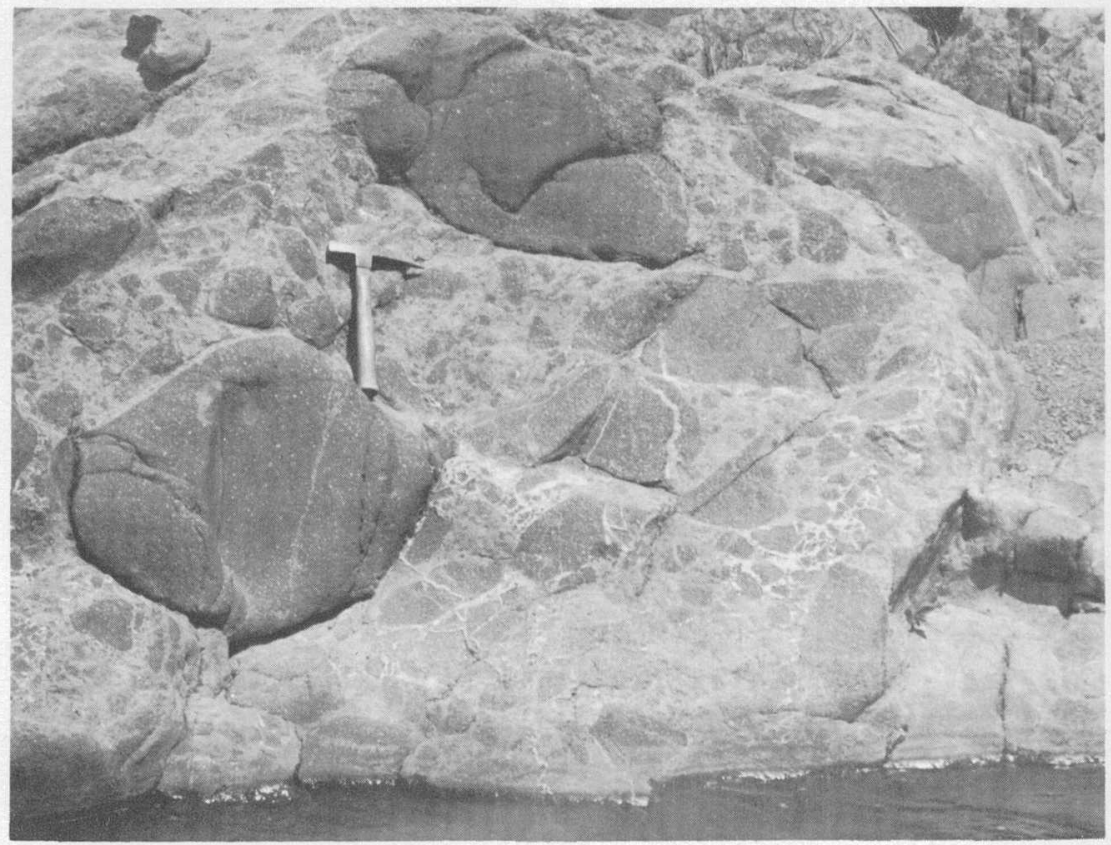

Figure 44.-Andesitic flow breccia in the Pachuca group along the Río Amajac, $3 \frac{1}{2} \mathrm{~km}$ south of Atotonilco el Grande, Hidalgo. 
Remains of fossil plants noted in the same section, collected by Carl Fries and the author in June 1955, yielded Tectochara? aff. T'. tornatc. This plant closely resembles $T$. tornata from the lower Headon beds (Ludian Eocene) of Engliand and from the Stampian and Chattian Oligocene of central Europe and is probably of early Tertiary age (R. E. Peck, oral communication, 1953). Ostracodes collected from the same beds as those of the plant remains were of no value for age determination. Older rocks are not exposed at Cuesta del Chiflón, but the Pachuca group directly overlies El Morro fanglomerate, Méndez clastic beds, and $\mathrm{El}$. Doctor limestone at several places a few kilometers northwest of San Juan.

\section{ZUMATE AND TEZUANTLA FORMATIONS AND DON GUINYÓ TUFF}

Dacite flows and breccias containing minor amounts of tuff uncomformably overlie the Cerezo rhyolite and the Pachuca group north and northeast of Real del Monte. They cover the hydrothermally altered and mineralized older rocks in the highest parts of the Sierra de Pachuca. These dacitic rocks make up the Zumate formation, named for Cerro Zumate, which rises $3 \mathrm{~km}$ north of Real del Monte. They show no quartz veining and are relatively unaltered and little faulted, but they are intruded by a few dikes. The Zumate formation, notable for the unusually coarse porphyritic texture of its lavas and explosion breccias and for its pinnacle-weathering erosion forms for example, Peña de los Frailes, Cerro de las Monjas (fig. 45), and Peña de las Ventanas attains a maximum thickness of about $300 \mathrm{~m}$.

South and southeast of Real del Monte, the Pachuca group is covered by the Tezuantla formation, which consists of rhyolite tuff with a basal conglomerate that contains abundant andesite fragments and is capped by dacitic and rhyolitic flow rock. The Tezuantla formation has a total thickness of about $150 \mathrm{~m}$.

Well-indurated andesite or decite tuff and breccia with horizontal lenses of black glass (welded tuff or ignimbrite) cover extensive areas along the highway between Ixmiquilpan and Huichapan north of Golondrinas, and in the vicinity of Tula (Cerro Xicuco, Arroyo del Corazón, Río Jilotepec). The name Don Guinyó is here proposed for this tuff, which appears to have been deposited on an irregular erosion surface. The type locality is near a high bridge that crosses Arroyo de Don Guinyó between Ixmiquilpan and Huichapan (pl. 3 and fig. 46); it furnishes good hand specimens of welded tuff. Under the microscope the tuff shows excellent collapsed pumice texture. Plagioclase of about $\mathrm{Ab}_{30}$ is abundant and orthopyroxene is also fairly abundant. This rock is probably low-silica dacite and is close to andesite. Megascopically similar tuff from the south base of Cerro Xicuco con-

6180960 0—62 - 
tains poorly preserved shard textures of microscopic size (C. S. Ross, oral communication, 1953). Several welded tuff layers, each a few meters thick, are interbedded with other pyroclastic beds to a total thickness of about $170 \mathrm{~m}$ at the base of Cerro Xicuco and along Arroyo de Don Guinyó.

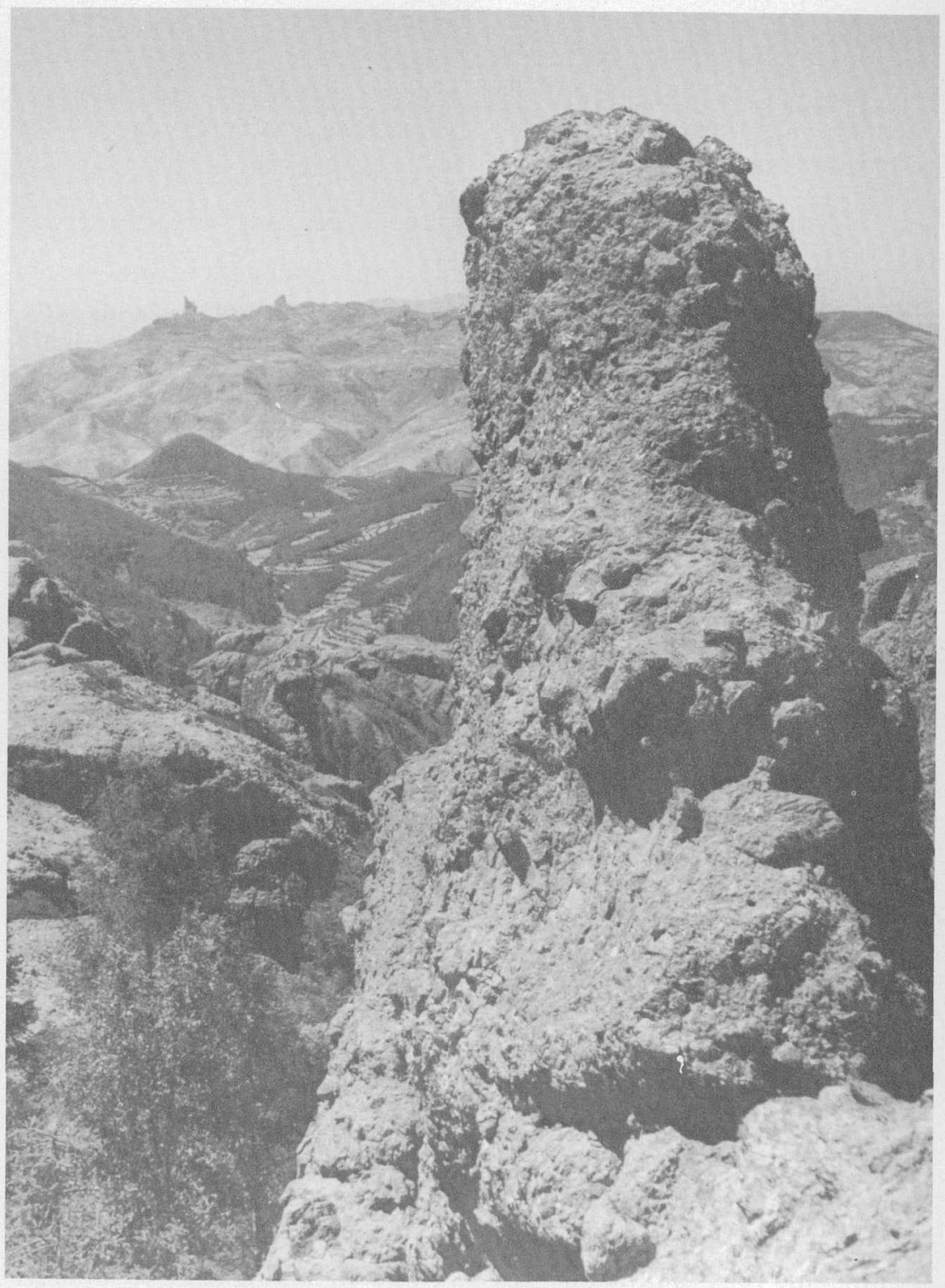

FIGURE 45.-Pinnacle composed of explosion breccia of the Zumate formation, Cerro de las Monjas, $3 \frac{1}{2} \mathrm{~km}$ west-southwest of Mineral del Chico, Hidalgo. 


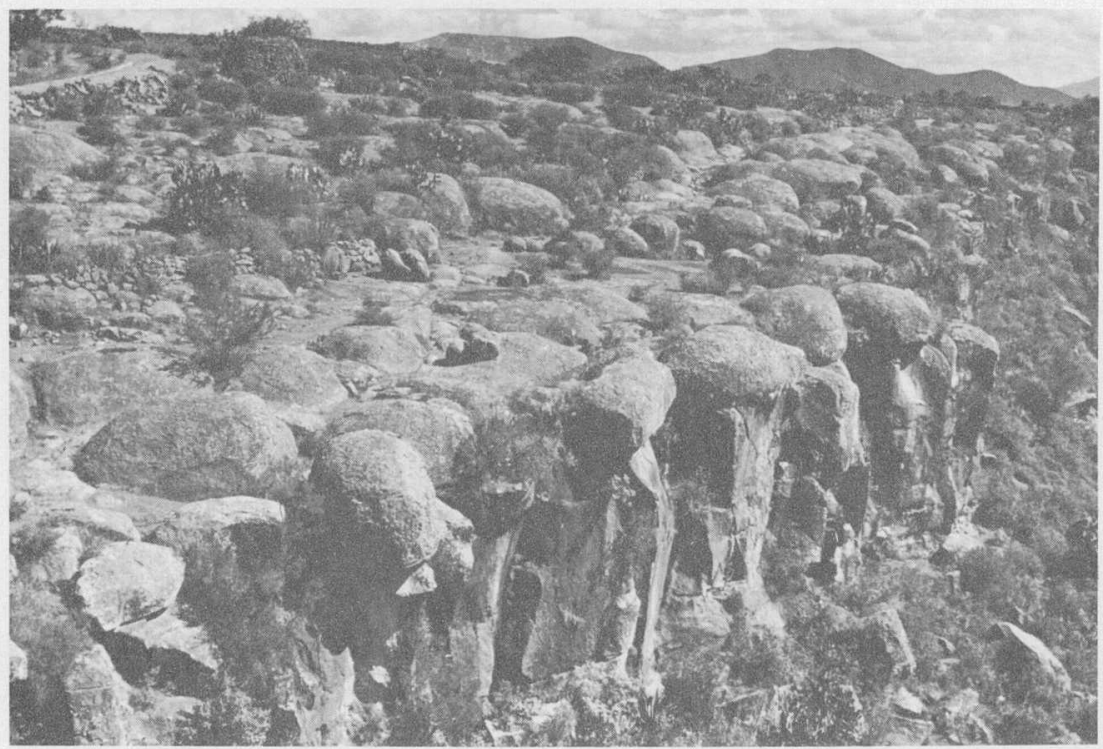

FIGURE 46. - Weathered surface of Don Guinyo tuff, looking east from the bridge over Arroyo de Don Guinyó, $26 \frac{1}{2} \mathrm{~km}$ west of Ixmiquilpan, Hidalgo.

Remains of oak, laurel, barberry, and other trees and smaller plants were collected in the rhyolite tuff of the Tezuantla formation from a quarry near Real del Monte by Edward Wisser, I. F. Wilson, and others. These remains are probably of Pliocene age, but their preservation is so poor and the identifications are so imperfect that a more precise age determination could not be made. Similar relations of the Zumate formation and the Don Guinyó tuff to older and younger rocks that resemble those of the Tezuantla formation indicate that the units are of the same age as the Tezuantla formation, that is, probably early Pliocene. The Chiquihuite dacite series of the Sierra de Guadalupe just north of Mexico City and the Ajusco and Iztaccíhualt andesite series southwest and east of Mexico City (Federico Mooser, written communication, 1956) are probably equivalent in age to the Zumate and Tezuantla formations and to the Don Guinyó tuff.

\section{SAN JUAN GROUP}

The San Juan group is named for a sequence of rocks along the Río San Juan, which joins the Río Tula to form the Río Moctezuma about $22 \mathrm{~km}$ west-northwest of Tasquillo. Along the Río Tula west of Tasquillo the San Juan group consists of basalt flows, water-laid tuffs, and volcanic conglomerate that is composed in part of pebbles and cobbles of older andesite and rhyolite (figs. 47 and 48). Throughout a broad belt extending from the Sierra de Pachuca westward toward 


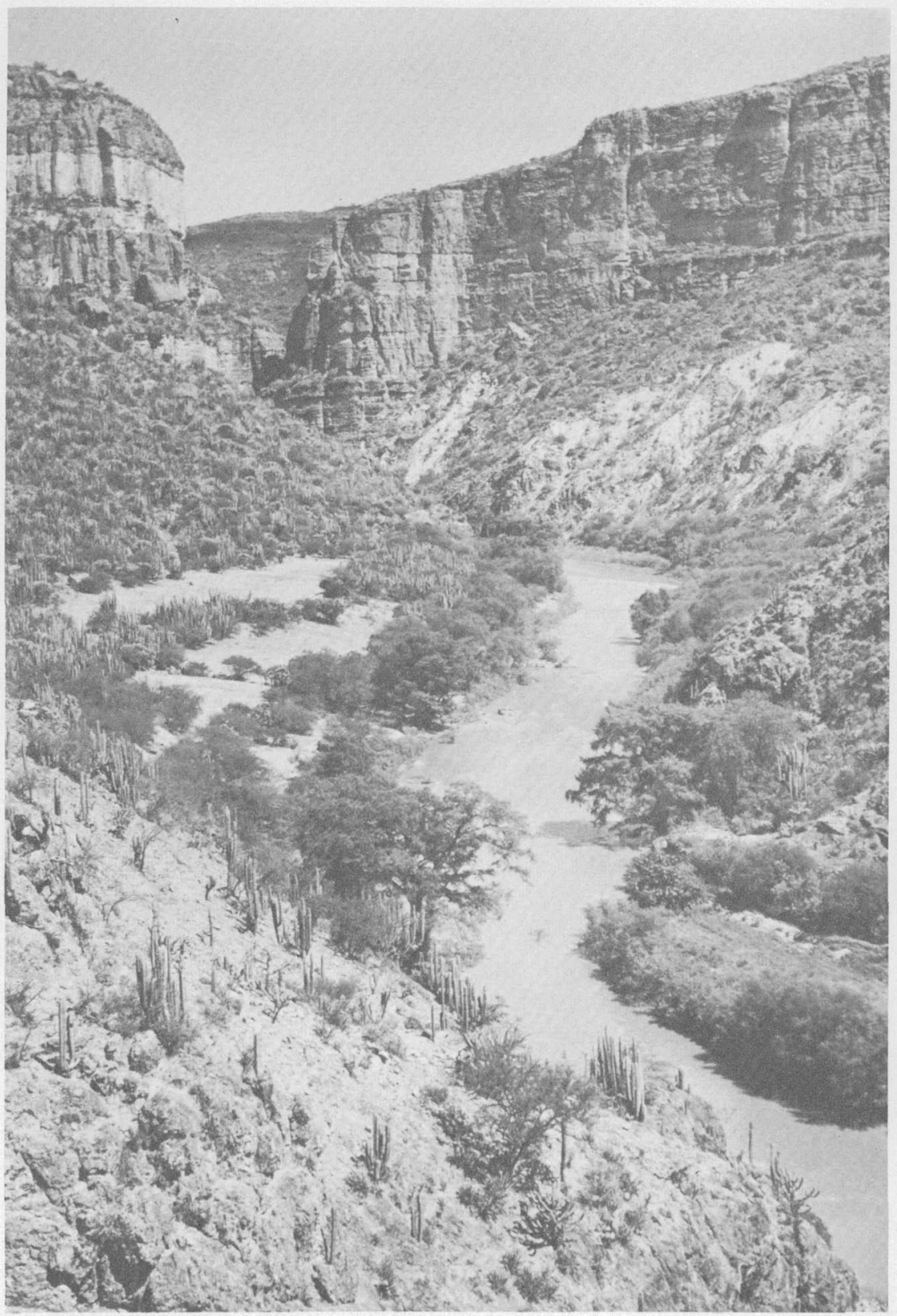

FIGURE 47.-Water-laid tuff of the San Juan group along the Río Tula, $4 \mathrm{~km}$ northwest of Tasquillo, Hidalgo. 


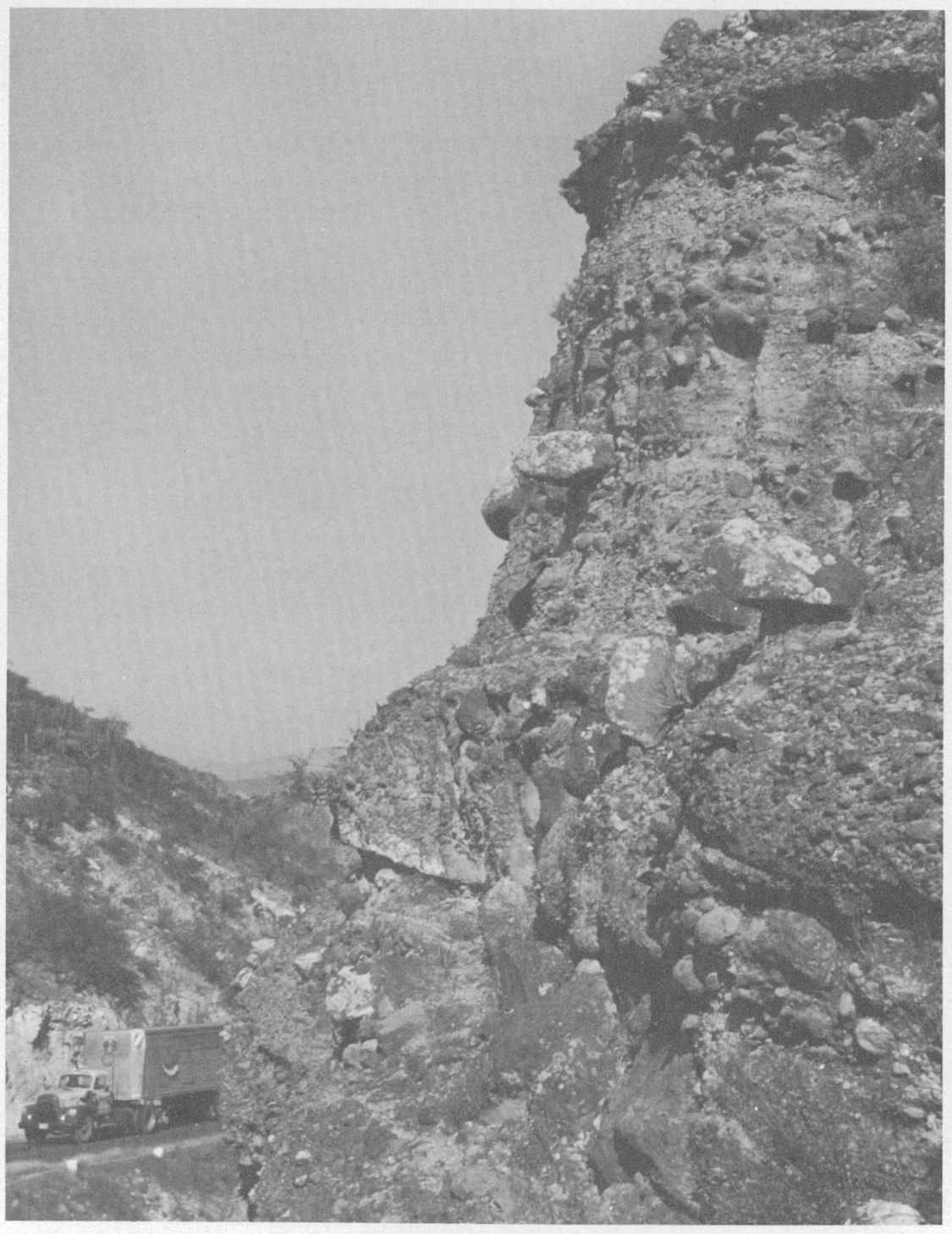

FIgURE 48.-Voleanic conglomerate of the San Juan group near the Río Tula, $31 / 2 \mathrm{~km}$ westnorthwest of Tasquillo, Hidalgo.

Tula the group consists of basalt and andesite flows which disconformably overlie older volcanic rocks. The San Juan group includes also basalt flows which overlie unconformably both the Las Trancas formation northeast of Zimapán and the El Doctor limestone southeast of Tula. 
In the Sierra de Pachuca the group is locally called the San Cristóbal basalt, after Cerro de San Cristóbal, which rises to the north of the city of Pachuca and is the discovery locality of the mineral cristobalite. The basalt, which is olivine bearing for the most part, tends to form the bulk of extensive high plateaus such as Cerro del Gorrión (about halfway between Pachuca and Tula) and of maturely eroded mountain masses such as Cerro de Los Pitos $(20 \mathrm{~km}$ south of Pachuca), and it also tends to cap high buttes such as Cerro de La Palma and Cerro Xicuco, near Tula. Westward the lithofacies changes from basalt to hornblende andesite in the lower part of the predominantly basaltic section northwest and west of Zumpango; the name Jalpan andesite refers to these latter rocks (Hibbard, $1955)$.

In the southern part of the area, the volcanic eruptions of the period were largely of a quiet, rather than an explosive type, and they probably occurred along fissures. Crater forms belonging to the San Juan group found only at Cerro de La Cantera $(10 \mathrm{~km}$ south of Actopan), where the scoriaceous core of a deeply eroded cinder cone containing basaltic bombs is exposed, and at Cerro de Los Pitos, where the eroded remnant of an enormous composite cone is exposed. Thicknesses of the group range from $10 \mathrm{~m}$ on Cerro de Cubitos just south of Pachuca to $80 \mathrm{~m}$ on Cerro Xicuco, $250 \mathrm{~m}$ near Tasquillo, and $400 \mathrm{~m}$ on Cerro del Gorrión.

Stratigraphic relations to other rocks indicate that the San Juan group ranges in age from middle to late Pliocene.

\section{TARANGO AND ATOTONILCO EL GRANDE FORMATIONS}

Clastic deposits that contain widely scattered lenses of lacustrine limestone and are locally capped by or intercalated with basalt flows cover a large part of the area, particularly the part corresponding to the Mexican Highland-that is, south west of a line passing roughly through Zimapán, Cardonal, and Atotonilco el Grande, Hidalgo. An extensive fill also extends northward from Atotonilco el Grande to Los Venados. The deposits with their associated lavas, where present, are represented by two facies: (a) older valley-fill deposits that are being actively and deeply eroded by the Tula, Amajac, and Metztitlán rivers and their tributaries, as well as by streams dissecting areas that border the Mexico Basin, and (b) younger deposits covering the floor of the Mexico Basin and major valleys; these are accumulating rather than being eroded. Deposits of the first of the facies are included in the Tarango and Atotonilco el Grande formations.

The Tarango formation is named for Tarango, a small town at the edge of the Mexico Basin $4 \mathrm{~km}$ southwest of Mixcoac, where 
poorly indurated tuff, tuff-breccia, volcanic gravel of fluvial origin, and thin beds of pumice crop out (Bryan, 1948). At the type locality the deposits consist in part of lahars, or mud flows (Arellano, 1953) and coalescing alluvial fans. Similar deposits occur under the floor of the Mexico Basin and fill low passes in the divide to the north and east. The lowest of the passes is between Huehuetoca and $\mathrm{EI}$ Salto, at 2,280 $\mathrm{m}$ above sea level, or $40 \mathrm{~m}$ above the surface of Lake Texcoco, which is the lowest part of the Mexico Basin. The Tajo de Nochistongo, an open drainage cut about $8 \mathrm{~km}$ long and as much as 30 or $40 \mathrm{~m}$ deep, exposes water-laid deposits of the Tarango formation, principally yellow-brown silt; it.also exposes three beds, each about $3 \mathrm{~m}$ thick, composed of sand-size pumice (fig. 15a). No beds with cobbles or boulders are exposed, lensing is inconspicuous, there are no lava flows, and the beds are horizontal and are apparently unfaulted in the great cut. Two drainage tunnels were later cut under a higher pass to the east between Zumpango and Tequiquiac, México. The west tunnel attains a maximum depth of $159 \mathrm{~m}$, is $12 \mathrm{~km}$ long, and is in the Tarango formation for almost its entire length, though it passes through deposits, including beds that contain andesite cobbles, that are coarser than those exposed in the Tajo de Nochistongo.

The Tarango formation is found north of the divide in the Valle del Mezquital, where it once filled a vast basin that lay at an altitude of 1,950-2,000 $\mathrm{m}$ above sea level. The formation occupied low places in the central part of the basin, extended partway up the slopes of hills and mountains that rimmed the basin, and formed isolated high points within the basin.

The Valle del Mezquital is being dissected by the Río Tula and its tributaries. The degree of excavation and removal of the Tarango formation is much more advanced to the north (Ixmiquilpan-Tasquillo area), where clastic deposits with a maximum total thickness of $400 \mathrm{~m}$ are exposed in escarpments, than to the south (Actopan-Tula area), where the beds are not as deeply dissected. Poorly indurated silt interbedded with pumice, sand, and clay compose the terrace escarpments except near high, steep mountain ranges like the Sierra de Juárez, where thick lenses of coarse gravel appear (Cuesta de Texquedó). Sand showing deltaic crossbedding is seen along the road to Chilcuautla (fig. 50), west of Ixmiquilpan, and near Texcaltepec, Hidalgo. Lenses of chert a few millimeters to a few centimeters thick occur near Florida, $25 \mathrm{~km}$ east-northeast of Ixmiquilpan. Limestone lenses as much as $12 \mathrm{~m}$ thick, but each one of less than a square kilometer in area, are exposed in quarries near Tezontepec de Aldama and Ajacuba, Hidalgo, and in Apaxco and Hueypoxtla- 


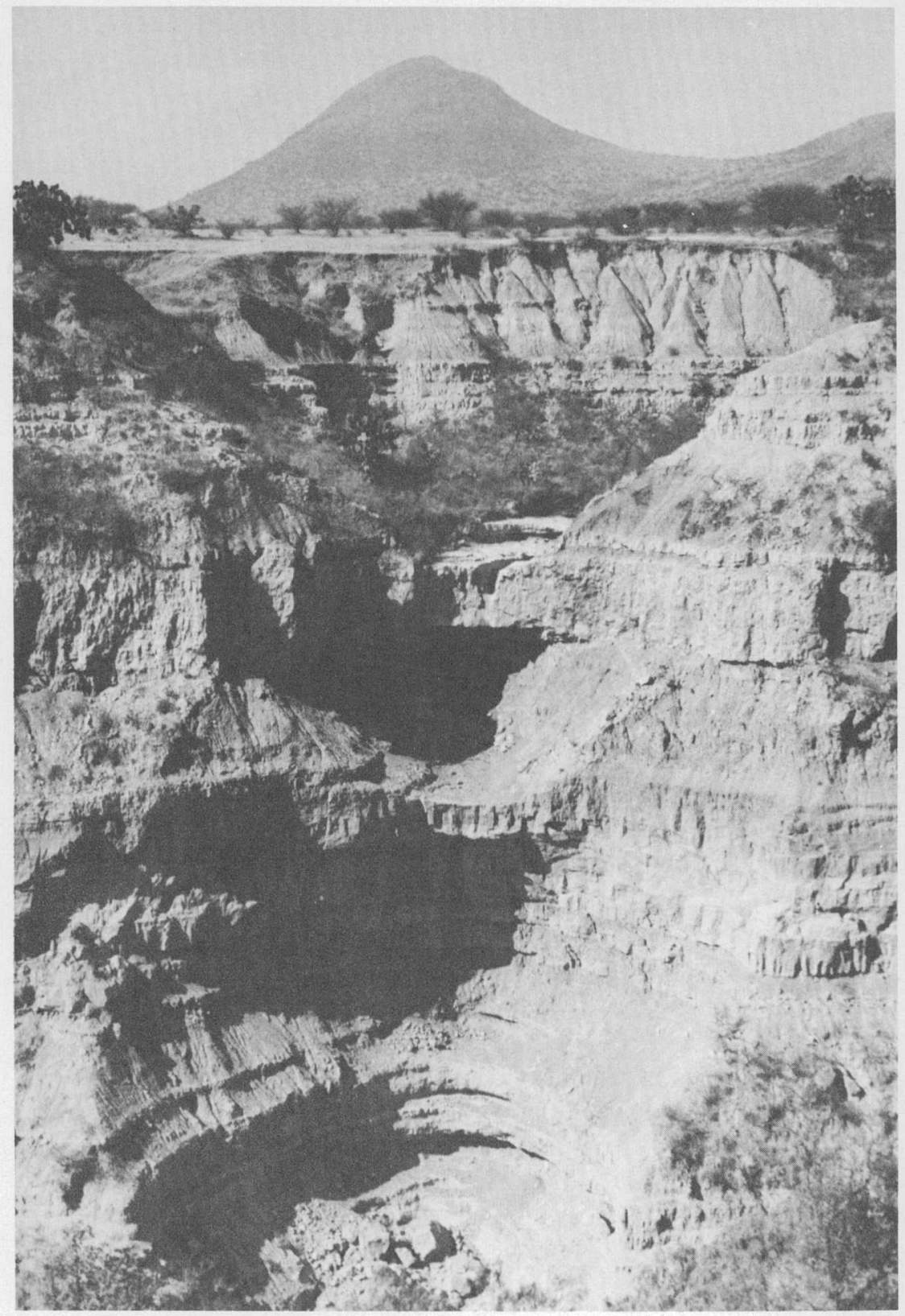

Figure 49. - Silt, sand, and pumice of the Tarango formation in the Tajo (drainage channel) de Nochistongo. The resistant, cliff-forming beds are pumice. 


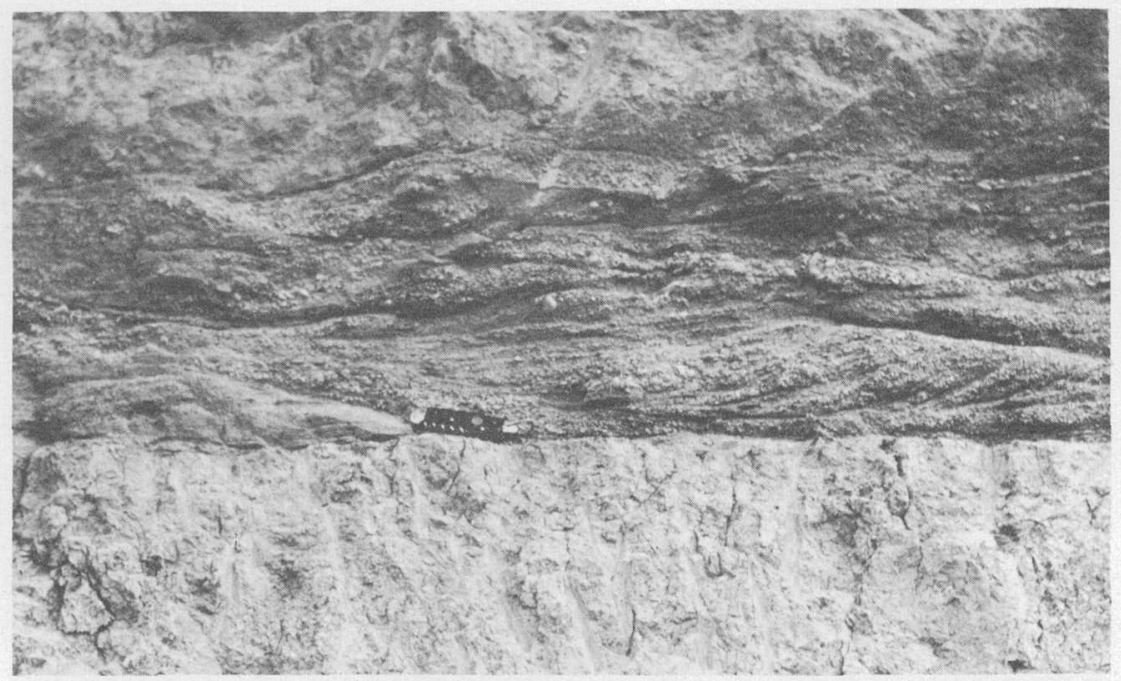

Figure 50.- Contact between crossbedded sand and underlying silt, both of the Tarango formation, along the road between Ixmiquilpan and Chilcuautla, Hidalgo.

Tlapanaloyan, México. A small lens of basalt lava occurs near the top of the formation at Actopan, Hidalgo, and numerous other basalt lenses occur in mountain valleys west of Pachuca.

The Atotonilco el Grande formation resembles the Tarango formation in its high content of unconsolidated clastic material, but it differs by having a much higher content of basalt lava. Outcrop distribution of the unit is along the east edge of the area mapped, on the northeast side of the upper Río Amajac and on both sides of the Río Metztitlán. The name of the formation is from Atotonilco el Grande, a town on a broad plain underlain by basalt flows and agglomerate to the south and by basalt interbedded with and underlin by unconsolidated clastic fill deposits to the east and to the north (fig. 51).

The Atotonilco el Grande formation is being actively dissected at the present time, and the Río Amajac and Río Metztitlán have carved deep gorges in the plain, which expose thick sections of the formation down to the underlying Pachuca group, El Morro fanglomerate, Méndez formation, and El Doctor limestone. At several places on the plain, both north and southeast of Atotonilco el Grande, rise hills of basalt agglomerate that are undoubtedly eruptive vents. Two of the vents are seen in section in canyon walls of the two rivers southeast of Atotonilco ei Grande and south of Los Venados. The maximum thickness of basalt lava is about $200 \mathrm{~m}$ and that of the whole formation is $500-600 \mathrm{~m}$. 


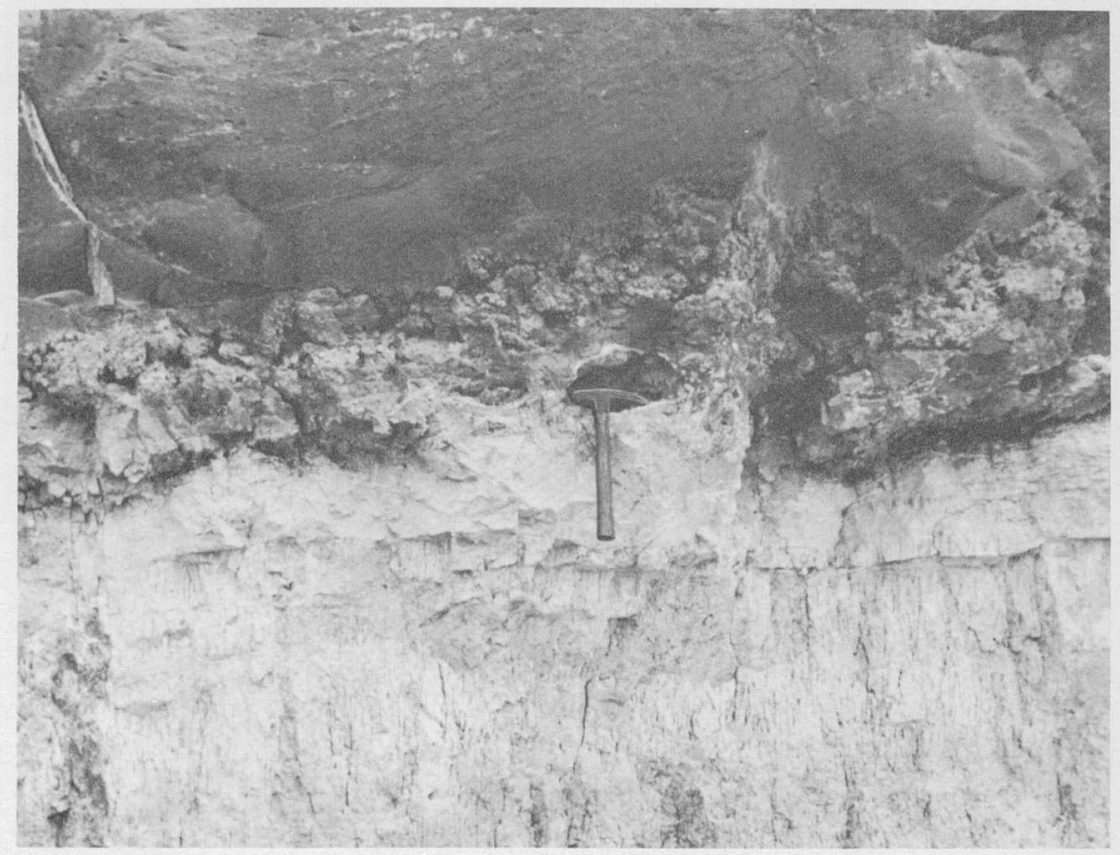

Figure 51.-Contact between basalt lava flow and underlying silts stone beds, both of the Atotonileo el Grande formation near Los Venados, Hidalgo.

Poorly preserved fossils consisting of mastodon and horse molars and bones, as well as mastodon tusks, were collected from clastic sediments that interealate and underlie six basalt flows about $15 \mathrm{~km}$ northeast of Atotonilco el Grande, in the vicinity of Vaquerías, Hidalgo. These fossils were described and the formations were assigned to the late Pliocene or early Pleistocene epoch by Villarello and Böse (1902). The remains should probably be referred to Cuvieronium shepardi and Equus cf. E. excelsus (M. Maldonado-Koerdell, oral communication, 1953). Molars of a mastodon found together with tusks and bones near Atotonilco el Grande (Wittich, 1913) resembled those of $C$. shepard $i$ in the cloverleaf form of the cuspids. The remains have been lost, so verification cannot be made, but the stratigraphic position of the beds in which they were found indicates a Pliocene age (A. R. V. Arellano, oral communication, 1953).

Fossils have not been found in the Tarango formation to date, so its age can be deduced only from stratigraphic position and geomorphic evidence. The unit is at least in part younger than the San Cristóbal basalt, which it overlies west of Pachuca. It is likewise younger than the hornblende andesite facies of the same age, which it overlies near Tequixquiac. Similarity of distribution and of stage 
in the erosion cycle suggest that the Tarango and Atotonilco el Grande formations are equivalent in age. The two formations are probably of late Pliocene age for the most part, but they may include deposits of early Pleistocene age.

\section{QUATERNARY SYSTEM}

\section{BASALT OF PLEISTOCENE AGE}

Numerous basaltic cinder cones in various stages of dissection occur near Zempoala (fig. 52) and Tizayuca, Hidalgo, and Zumpango,

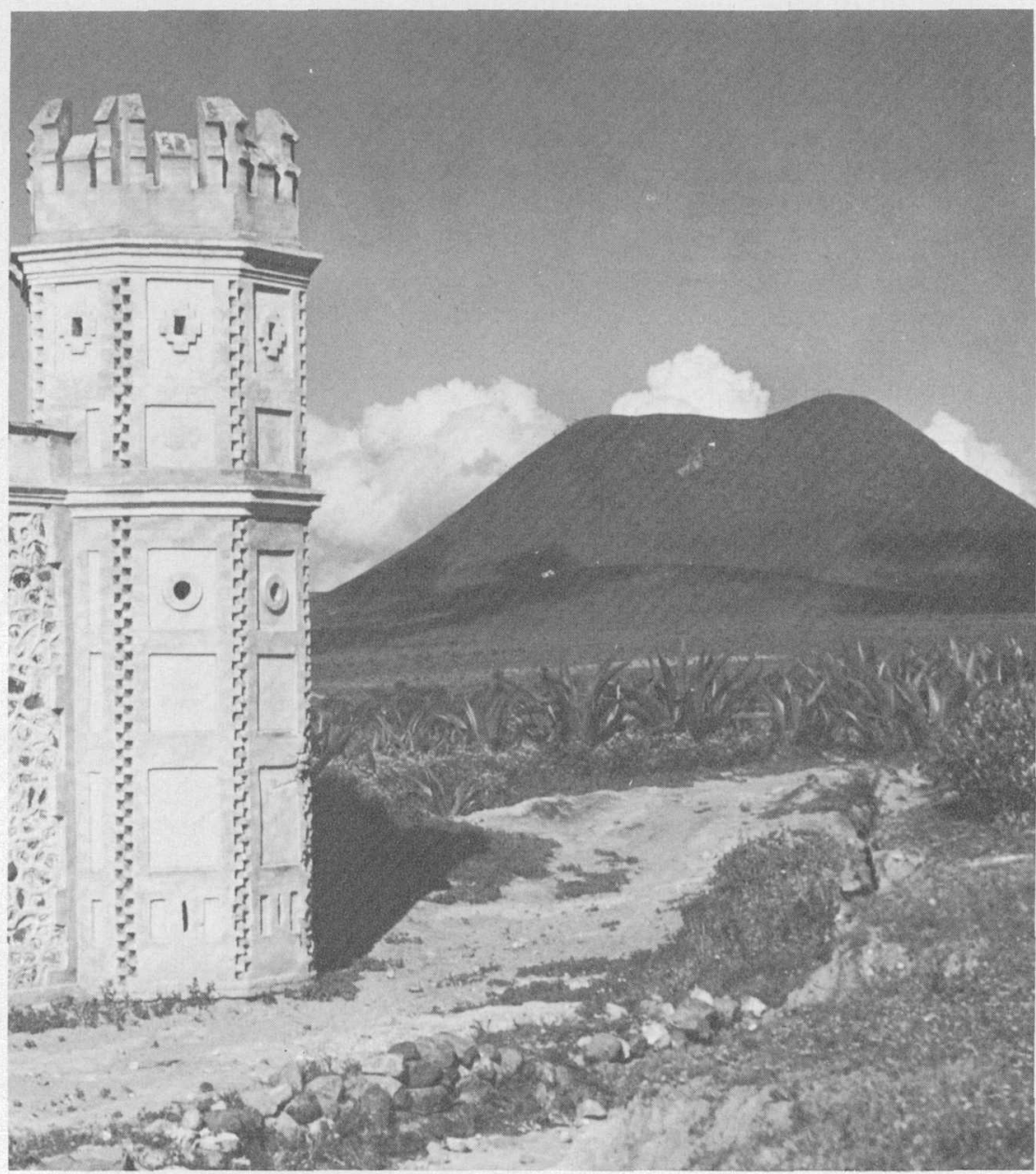

Figure 52.- Undissected basaltic cinder cone near Zempoala, Hidalgo. 
México, in the southern and southeastern parts of the area; a few occur near Pachuca, but none are found in the northern and western parts of the area. Thin basalt flows, some of which can be related directly to cones (for example, Cerro Dolores) and others to extrusive domes, or places of quiet extrusion of lava (for example Cerro Coatepec), are distributed widely to the west and to the north, especially along the valleys of the Río Tula and Río Alfajayucan.

The Río Tula is incised for the most part in the Tarango formation and is bordered by remnants of basalt flows from its headwaters near the north end of the Tajo de Nochistongo nearly to Ixmiquilpan, a distance of $70 \mathrm{~km}$. The river drops off the edge of one of these flows at El Salto, Hidalgo. The remnants occur like terraces at four distinct-levels on either or both sides of the river and along the lower courses of some of its tributaries. The remnants are discontinuous, and the basalt is clearly not interbedded with the clastic deposits. The lava evidently flowed down successively lower levels of the valley, so that the highest flow was the first one and the lowest flow was the last. Three basalt-lava terraces can be seen in one segment of canyon wall about $5 \mathrm{~km}$ north of Progreso, Hidalgo. Two different levels of basalt form narrow mesas or terraces south of Alfajayucan, where lava has filled ancient valleys eroded in the Tarango formation.

The flows, which are of black olivine basalt containing abundant plagioclase laths of minute size and scattered olivine phenocrysts as much as 2 or $3 \mathrm{~mm}$ in diameter, must have been very fluid, for they are uniformly thin (4-10 m thick along the Río Tula). They flowed for many kilometers (sources of the Alfajayucan lavas and the first of the Tula flows are outside the area mapped), and they are without brecciated zones at top and bottom (flow-breccia zones are characteristic of more viscous lavas). Baked zones of reddish calcined soil extend 5-20 cm below the flows into the underlying clastic deposits, particularly where the deposits are silty. The cones are mostly of unindurated black ash and lapilli (fig. 53), which through weathering become a yellow-brown soil, but at or near eruptive vents a wellcemented red agglomeratic scoriaceous rock, known as tezontle, commonly occurs.

Basalt in the Tula and Alfajayucan valleys is clearly of postTarango age, and hence a Pleistocene age can be assigned to it. The fact that the flows are not nearly as deeply eroded as those of the San Cristóbal basalt (middle and late Pliocene) also indicates a Pleistocene age; moreover, the constructional form of the cinder cones indicates that their age cannot be great. Basalt lava of Pleistocene age is further distinguished from that of Pliocene age by the degree of weathering; at no place within the area do the younger lavas show 


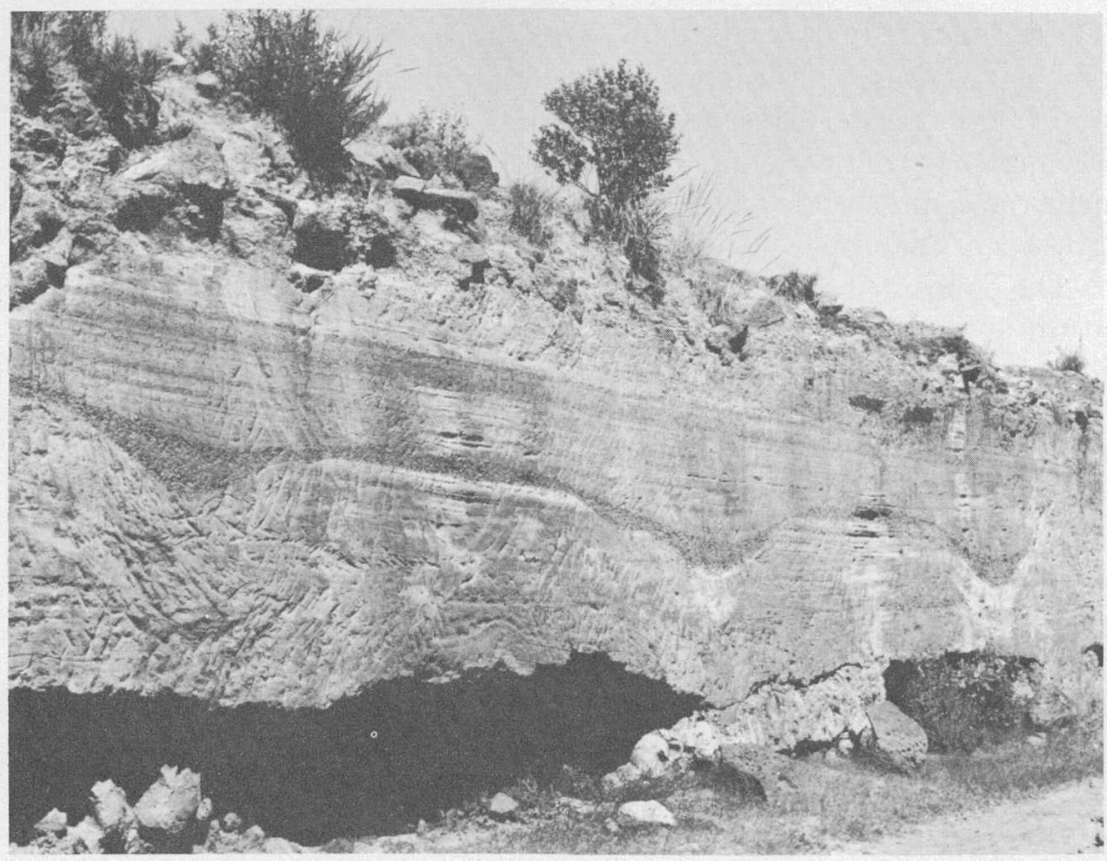

Figure 53.-Basaltic ash and lapilli of Pleistocene age in road cut southeast of Zempoala, Hidalgo, showing channel fillings along the lapilli bed.

depths of decomposition of more than a few centimeters, though the red residual soil has formed to a depth of $5 \mathrm{~m}$ or more on top of basalt lava of the Atotonilco el Grande formation (late Pliocene). In general, accumulations of Pleistocene basalt within the area studied are not as thick as those of the same age outside the area (south of Mexico City), nor are they comparable in thickness to those of Pliocene age in the area.

\section{CLASTIC DEPOSITS AND SOILS OF PLEISTOCENE AND RECENT AGES}

Clastic deposits of Quaternary age are found in the México Basin, on the low parts of bordering slopes, and in most of the open valleys outside the closed Mexico Basin. Soils of Quaternary age are ubiquitous - they even cover the eroded Tarango formation and are found on the summits of the highest mountains.

These Quaternary sediments, together with the residual and reworked soils, have been divided into formations by various investigators (Bryan, 1948; de Terra, 1949; Arellano, 1953; Zeevaert, 1953). In the present report, however, deposits and soils of post-Tarango age are shown on the map only where the thickness exceeds $3-5 \mathrm{~m}$ and where their areal extent is great; they are not divided into formations. 
These deposits include silt; clay, sand, and ash laid down in lakes and on their shores (as the Mexico Basin), alluvium (in stream valleys), and fanglomerate, talus, and other locally derived materials that have been transperted for short distances (from mountain slopes). Evaporites are interbedded with the lacustrine beds; and caliche may be present in the upper layers of all types of clastic materials.

The deposits in the Mexico Basin between Mexico City and Pachuca attain a maximum thickness of $100 \mathrm{~m}$ or more. Lacustrine deposits identified as of Wisconsin (late Pleistocene) age (Clisby and Sears, $1955)$ were found at $75 \mathrm{~m}$ below the surface in Mexico City. The cen. tral part of the city of Pachuca is built on alluvium $200 \mathrm{~m}$ thick, but it is not known what part of the total thickness is of post-Tarango age. The maximum thickness of alluvium that covers what remains of the dissected Tarango formation in the valley of Ixmiquilpan is over $10 \mathrm{~m}$.

A femur and part of a jawbone of Elephas were found in Recent sediments near Lagunilla, Hidalgo, between Actopan and Ixmiquilpan, but the fragmentary nature of the remains made a determination as to species impossible (Müllerried, 1939). Many mammoth and horse remains have been found in gypsiferous silt in a quarry located about $31 / 2 \mathrm{~km}$ southeast of Tula; these include a jawbone of $\mathrm{Mam}$ muthus (Parelephas) columbi (fig. 54). The most significant fossiliferous vertebrate locality within the area mapped is that of Barranca de Acatlán, just northwest of the older drainage tunnel between Zumpango and Tequixquiac. There, remains of mammoths, horses, dogs, rodents, and other mammals, as well as of reptiles and birds, all of late Pleistocene age, have been found (Maldonado-Koerdell, 1948; Hibbard, 1955).

Caliche has a wide areal distribution in the soils of the region, its presence and abundance being functions of the bedrock lithology, local climate, height of the water table, susceptibilty to erosion, and availability of coarse unconsolidated material. The most favorable bedrock lithology for caliche production in the area of plate 3 is that of the El Doctor Limestone, and the least favorable is that of Geyne's Cerezo rhyolite. All the rock formations of Mesozoic age are strongly calcareous and therefore have tended to be productive of caliche. Caliche-bearing soils have formed on basalt of the San Juan group and on some of the later flows, but such formation has been less pronounced on the andesite and dacite of the Pachuca group. Geyne's Cerezo rhyolite and the Don. Guinyó tuff are mostly unproductive, owing to the scarcity of calcium-bearing minerals in those rocks. All the terrigenous sediments are caliche forming. 


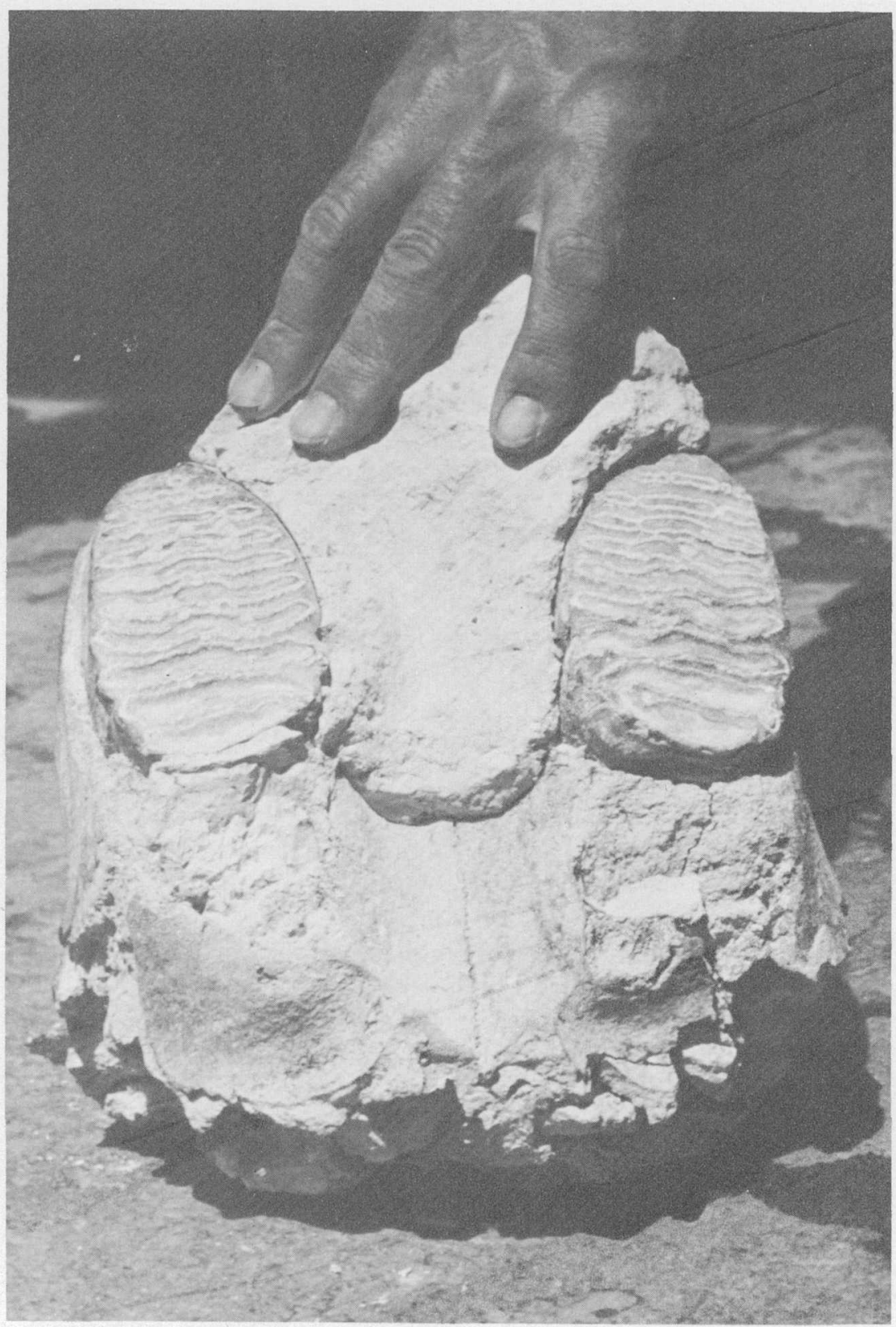

Figure 54.-Jawbone of Mammuthus (Parelephas) columbi, found near Tula, Hidalgo. 
Caliche tends to be most abundant in the region of least rainfall, that is, in the Ixmiquilpan valley, on adjacent slopes underlain by the El Doctor limestone, and eastward toward the gorges of the Río Amajac. In that region caliche forms a hardpan, commonly about $20 \mathrm{~cm}$ thick, under black topsoil that is $8-30 \mathrm{~cm}$ thick. Near Pachuca, in a region somewhat less arid than that of Ixmiquilpan, the caliche does not form a definite hardpan but is more dispersed through the soil, generally above depths of 1-1.5 m (fig. 55). Caliche does not occur on the humid summits and upper northern slopes of the Sierras de Pachuca and Juárez, where precipitation is much heavier than in adjacent valleys, and it is also absent in some other mountaintop areas, even where these areas are underlain by the El Doctor limestone. In El Doctor outcrop areas, a red lateritic soil tends to form.

North of Atotonilco el Grande, in the northeast part of the area of plate 1 ; the caliche and red soil are extremely sensitive to climatic change caused by difference of altitude. For example, on a forested limestone hilltop at El Palmar, Hidalgo, about 2,100 m above sea level, there is much red soil and no caliche, yet in a barren limestone valley at La Presa, $1,700 \mathrm{~m}$ above sea level and $2.3 \mathrm{~km}$ east of el Palmar, there is no red soil, and much of the surface is "armor plated" with caliche layers that extend downward to a depth of several meters.

Widespread stripping of thin black topsoil on many gentle slopes in the arid region of Ixmiquilpan exposes a white surface of hard caliche underneath. The stripping appears to be going on today at a rapid rate, probably due to destruction of a sparse cover of desert grasses through overgrazing by sheep and goats. Thus exposed, the surface of caliche is subject to solution weathering and rapid runoff rather than retention of the solutions. Moreover, wherever headward retreat of gullies is taking place because of lowering of local base level or where erosion has been accelerated for any other cause, the removal of caliche by leaching tends to be more rapid than its formation. Therefore the presence and abundance of caliche depends to some degree upon the susceptibility of the soil at a particular place to erosion.

A short distance south of Puerto Blanco, Hidalgo, $16 \mathrm{~km}$ eastnortheast of Zimapán, a mantle of caliche about $30 \mathrm{~cm}$ thick forms an overhang at the crest of a narrow, steep-sided ridge. The mass dips parallel to the east slope of the ridge, but the overhang is on the west edge of the crest; it tops the headwall of a landslide in west-dipping shale of the Las Trancas formation. The landslide, which contains fragmental blocks of caliche and of shale, is a product of mass-wasting processes that are destroying the caliche mantle in many places. 


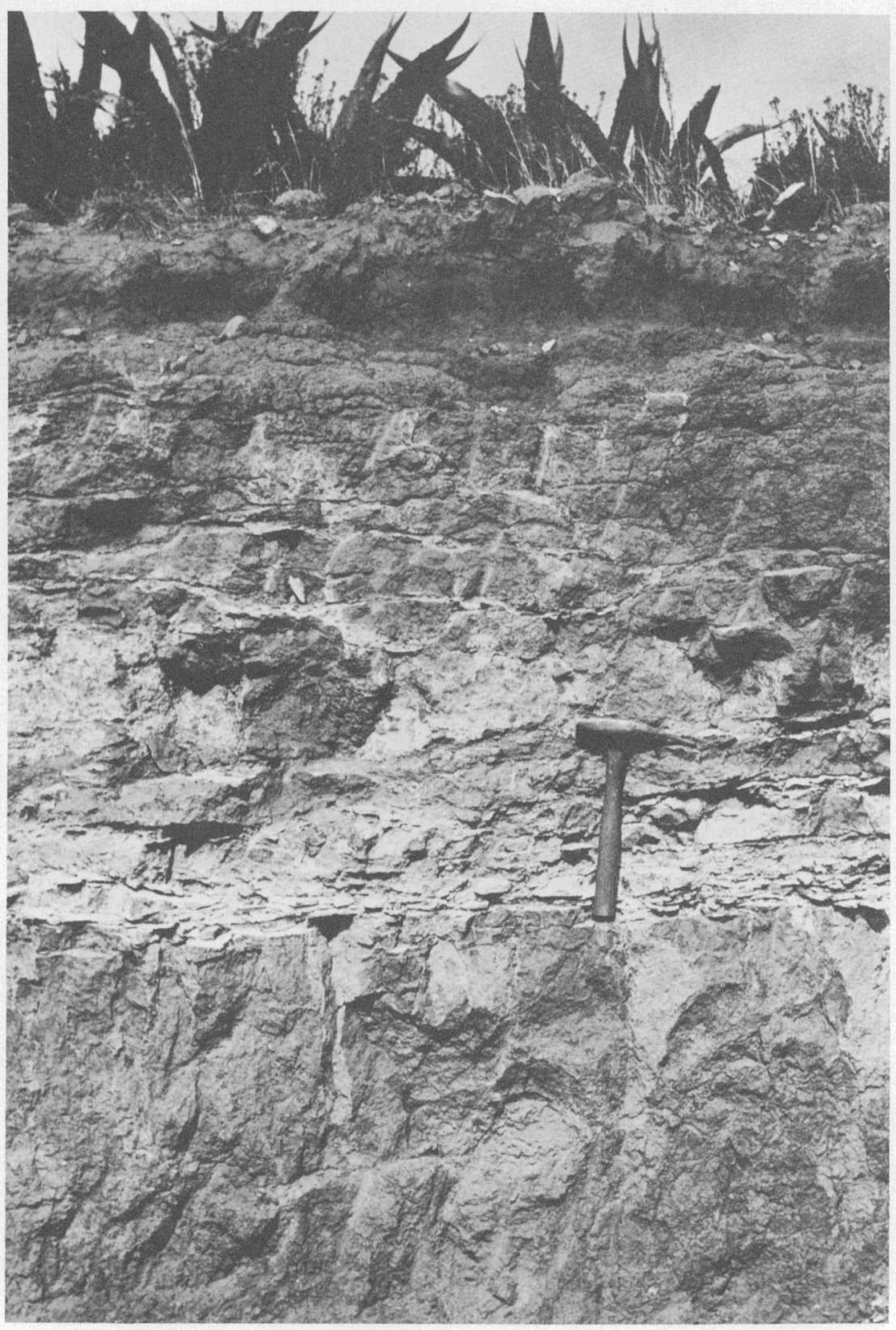

Figure 55.-Caliche (white) in volcanic soil near Pachuca, Hidalgo. 
In the Apaxco-Tula region (southwest part of the area of pl. 3), in the Ixmiquilpan region (central part of the area), and in the region north of Atotonilco el Grande (northeast part), the sloping sides of barren limestone hills and mountains are partly mantled with limecemented breccia. The breccia, a coarse slope-wash deposit made up largely of angular limestone float in which caliche has formed, forms a surficial lens which is thickest where the buried bedrock slope begins to flatten and wedges out both up the slope and outward from the base. The bedrock surface upslope from the point of the wedge is commonly much steeper than the caliche-hardened detrital surface below. Thus, the availability of coarse detrital material seems to be an important factor in local distribution of caliche.

Three fossilized caliche zones ranging in thickness from $5 \mathrm{~cm}$ to nearly $2 \mathrm{~m}$ are in the soil profile at Tepexpan, México, $25 \mathrm{~km}$ south of the area of plate 3 (de Terra, 1949, p. 25-30). These zones probably represent dry intervals of Pleistocene time separated by periods of greater humidity. Caliche is apparently not being formed at the present time at Tepexpan, where the rainfall is over $500 \mathrm{~mm}$, at Zimapán, where the rainfall is $373 \mathrm{~mm}$ (Simons and Mapes, 1956, p. 36). The same statement can be made for other parts of the area of plate 3 , not only where the rainfall is greater than at Zimapán, but where the erosion of a more arid region is exceptionally rapid. However, the caliche in the limestone talus described above seems to be forming today locally, for if it were not, loose float without caliche should be more abundant than it is on some of the limestone slopes that are partly mantled with lenses of breccia in which there is caliche.

\section{INTRUSIVE ROCKS}

The intrusive rocks in the area are in shallow dikes and plugs, many of which occupy former vents that served as feeders for overlying extrusive rocks. Five types of rock have been recognized in the dikes of the Sierra de Pachuca; in order of decreasing age these are of andesite, dacite, rhyolite, felsite, and basalt. The first three cut rocks of the Pachuca group and are probably of late Miocene age; the felsite cuts the Zumate dacite and is probably of late Pliocene age. Andesite dikes and sills intrude the marine sedimentary rocks at many places, as, for example, just east of Cerro Prieto near the north end of the area, along the Río Amajac, near the northeast base of the Sierra de Pachuca, and along the Río Metztitlán near Los Venados. Rhyolite dikes intrude andesite of Oligocene and Miocene ages near Pachuca and Real del Monte in the Sierra de Pachuca, near Magdalena in the Sierra de Actopan, near Tepeitic in the Sierra de Xinthé, and at many other places. Rhyolite stocks 
or plugs form Cerro Chillete and Cerro del Judío, south and west, respectively, of Pachuca, and a hill just west of Puerto Xithá and south of Zimapán. There are several other such intrusive rocks in the Pachuca-Real del Monte mining district, all of late Miocene age. Rhyolite plugs, a few meters to less than $100 \mathrm{~m}$ in diameter, intrude the El Doctor limestone at several places about 4-6 km southeast of Tula; these intrusive bodies are too small to be shown on plate 3 .

Intrusive breccia occurs in the outer zones of both rhyolite dikes and rhyolite plugs. The breccia was formed when the magma chilled at its contact with the walls of the intrusive body and locally reached a higher viscosity, so that the contact zone was fragmented while fluid magma in the core was still moving.

Flow structure, where present, tends to be parallel to the walls of the intrusive bodies of the region, particularly in the rhyolite stocks south of Zimapán and near Pachuca, where funnellike shapes coincide with strikes and dips in the bodies. Locally the flow structure is wrapped around inclusions or exhibits a fanlike pattern (fig. $56)$.

Probably no large bodies of coarse-grained intrusive rocks crop out within the area mapped, although just northwest and north of the area monzonite (Barranca de Tolimán) and diorite (San José del Oro-La Encarnación are exposed.

\section{STRUCTURE}

Structural features of the rocks of south-central Hidalgo and northeast México are both primary and secondary. Primary structural features include unconformities, flow structures, and the shape of intrusive bodies; these are described in the sections on stratigraphy and intrusive rocks. The secondary structural features include folds, fracture cleavage, and faults in the Las Trancas, Santuario, El Doctor, Cuautla, Soyatal, Mexcala, and Méndez formations. Alluvium faulted in places against bedrock shows that some of the faulting is recent. Joints are very common. They were not mapped by the author, but they are briefly described on page 135 .

\section{FOLDS}

The rocks of Mesozoic age have been folded into major synclines and anticlines whose axes trend from north to northwest. Crests of the major anticlines are from 8 to $25 \mathrm{~km}$ apart, and the flanks are made up of lesser anticlines and synclines. Many of the folds are overturned steeply toward the east or northeast (fig. 40). Axes are commonly plunging, and structural saddles have formed in places. Names are here proposed for each major structural feature except 


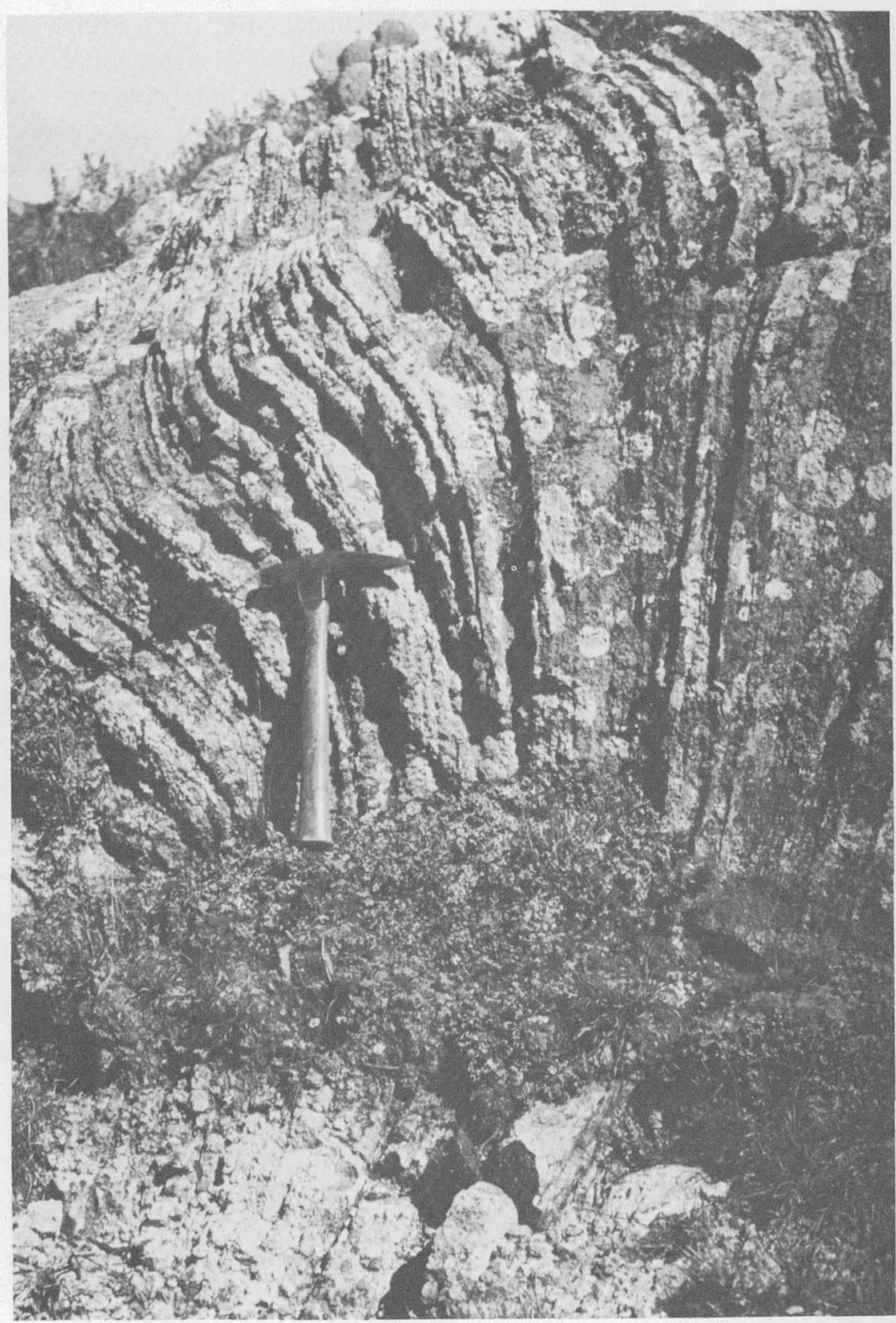

Figure 56.- Flow structure, accentuated by weathering, in a small rhyolite plug near San Bartolo, Hidalgo. 
the Piñón anticline, which was named in a previous publication (Simons and Mapes, 1956, p. 29).

The general trend of folds in the region is north-northwest, but locally the folds are parallel or subparallel to the long sides of the north-striking Ixmiquilpan bank or to the south side of the Jacala bank. These characteristics of the structure are portrayed on the map by outcrop patterns more fully than by bedding symbols. Bedding symbols were not used at many places on the map where observed strikes and dips are not known to represent the general attitudes of: limbs of mappable folds.

The Cerro Blanco anticline is a complex major fold that raises the El Doctor limestone in the northeastern part of the area. Its width is about $25 \mathrm{~km}$. The fold is deeply eroded by the Río Amajac and its tributaries, and this erosion has exposed such structural details as lesser folds only 1-2 km wide or less and minor folds a few meters apart. In places the upper limb of the main fold is complexly deformed by lesser round-crested and chevron folds whose axial planes dip both east and west, as for example, northeast of Molanguillo, Hidalgo, or 32-34 km northeast of Ixmiquilpan. The highest point of the fold is cut by the Río Amajac at Cañon de las Dos Peñas, a spectacular gorge $800 \mathrm{~m}$ deep.

The El Doctor limestone crops out along the anticline far south of the general outcrop area of rocks of Mesozoic age and forms a reentrant $15-20 \mathrm{~km}$ long into the area of rocks of Cenozoic age. Within the area of the reentrant, small patches of volcanic rock occur, generally along synclinal axes of lesser members of the complex major fold. Because the limestone is so resistant to erosion, the structural high was a topographic high when the country was partly covered by volcanic rocks and clastic deposits in Cenozoic time, so that the Cerro Blanco anticline was covered more thinly than terrain east and west, and some parts of it may not have been covered at all.

The Nicolás Flores, Bonanza, and Piñón anticlines form a triple structural feature in the northern part of the area and raise the Las Trancas formation in three outcrop belts. The width of the complex triple structure is about equal to that of the Cerro Blanco anticline. The three anticlines plunge southward and disappear under a thick cover of Cenozoic deposits; where they approach the Jacala bank, at the northern edge of the area, they are deflected sharply toward the west. The Nicolás Flores, Bonanza, and Piñon features may be classed as breached anticlines whose roofs of resistant El Doctor limestone have been eroded to expose the less resistant phyllitic shale underneath. The anticlines have tended to form topographic lows rather than highs and are therefore covered to a considerable degree by vol- 
canic rocks of Cenozoic age, particularly in the Sierra de Juárez. The Piñon anticline lines up with the Pingüical anticline to the northwest. Cerro del Pingüical is N. $38^{\circ} \mathrm{W}$. of the south end of the Piñon anticline, at a distance of about $55 \mathrm{~km}$.

The Los Venados syncline, coinciding with a topographic low in the northeastern corner of the area, includes the northeast limb of the Cerro Blanco anticline and, of course, the southwest limb of the next anticline to the northeast. The axial area of the complex major syncline is underlain by the Méndez formation and is covered to a great extent by clastic rocks and basalt of Cenozoic age. The outcrop width of younger rocks widens southeastward, outside the area here described, and narrows northwestward; this variation in width suggests that the Los Venados syncline has a general plunge toward the southeast. These rocks are undergoing active dissection by the Río Metztitlán, whose course roughly follows the synclinal axis.

The west limb of the Cerro Blanco anticline and the limb of the Nicolás Flores anticline make up the Chalmita syncline. The axial area of the syncline is underlain by the Méndez formation, which is covered for many square kilometers by volcanic and clastic deposits of Cenozoic age. The position of the Sierra de Actopan, which is made up of volcanic rocks, coincides with the axial area of the Chalmita syncline extended southward, and suggests that the volcanic rocks possibly filled a topographic low. If so, the Sierra de Actopan exemplifies inversion of topography on a grand scale.

The Xinthe syncline in the western part of the area is almost completely covered by deposits of Cenozoic age; hence, its exact position is hypothetical. The axis was traced by the writer along a zone of sparsely scattered windows of the Mexcala formation, and, where these are lacking, it was assumed to be parallel to the western edge of the Ixmiquilpan bank. The axial zone of the syncline very likely coincides in a general way with the Sierra de Xinthé; if so, this volcanic mountain range represents an inversion of topography like that of the Sierra de Actopan.

The area of the central part of the insert map at the bottom of plate 1 lies within the axial zone of the San Lorenzo syncline. The Mexcala formation crops out north of San Antonio Tezoquipan, Hidalgo, 221/2 $\mathrm{km}$ west of Ixmiquilpan, where older rocks crop out both to the east and southwest. The trend of the synclinal axis changes sharply from nearly due north to N. $38^{\circ} \mathrm{W}$. near San Antonio Tezoquipan.

The folding is post-Mexcala-Méndez and pre-El Morro in agethat is, between Late Cretaceous and late Eocene. Evidence in the Tampico region to the northeast indicates that folding, probably not much older than late Paleocene, affected the Paleocene beds of the 
Chicontepec group (Muir, 1936); the folding is definitely older than late Eocene (Fries and others, 1955), however.

\section{FRACTURE CLEAVAGE}

The same forces that caused folding produced conspicuous closely spaced fracture cleavage in the clastic rocks of the Las Trancas, Santuario, Soyatal, and Mexcala-Méndez formations, particularly in the first and last named of these units (fig. 57), and also in argillaceous beds of the El Doctor limestone (fig. 58). However, the most pronounced effect was on the less argillaceous limestone beds of the $\mathrm{El}$ Doctor, Santuario, and Soyatal formations, which tended to flow plastically. Many of the chert lenses were shattered during the plastic movement of the predominantly limestone rocks in which they are enclosed.

The fracture cleavage is subparallel to the axial planes of the folds; its attitude nearly coincides with that of the axial planes in the axial zones, but it diverges as much as $10-20^{\circ}$ on the limbs of folds. Complex minor folds in which the axial planes of individual members are not parallel exhibit fracture cleavage which is subparallel to a principal axial plane but which cuts other planes at high angles. Where the folding is not too complex, fracture cleavage may be used to determine whether a bed is undisturbed or overturned; in simple folds where the cleavage and bedding dip in the same direction but the attitude of beds is steeper than that of cleavage, the section is overturned. Unfortunately, fracture cleavage gives no indication as to the magnitude of the fold whose limb is overturned; the fold may be a minor one on the upper limb of a larger overturned fold. Fracture cleavage at any one place is of limited value, therefore, in the interpretation of major structure.

An aspect like that of ripple marks is present at some localities where fracture cleavage cuts bedding planes (fig. 59).

\section{THROST FAULTS}

A nearly horizontal fault on Cerro Daxí, along which the El Doctor limestone was thrust over the Mexcala formation, was described in an earlier paper (Simons and Mapes, 1956, p. 31). Thrust faulting in the Mexcala and Méndez formations on an outcrop scale was observed at various places, particularly on the south slope of Cerro Tunititlán (2 km northwest of Mixquiahuala, Hidalgo) and at the headwaters of Arroyo del Enebro $20.5 \mathrm{~km}$ east of Ixmiquilpan. At those places, relatively competent siltstone is thrust over less competent shale, and the direction of thrust is toward the east. Evidently the same compressive force that caused overturning of folds toward the east contemporaneously caused the overthrusting. 


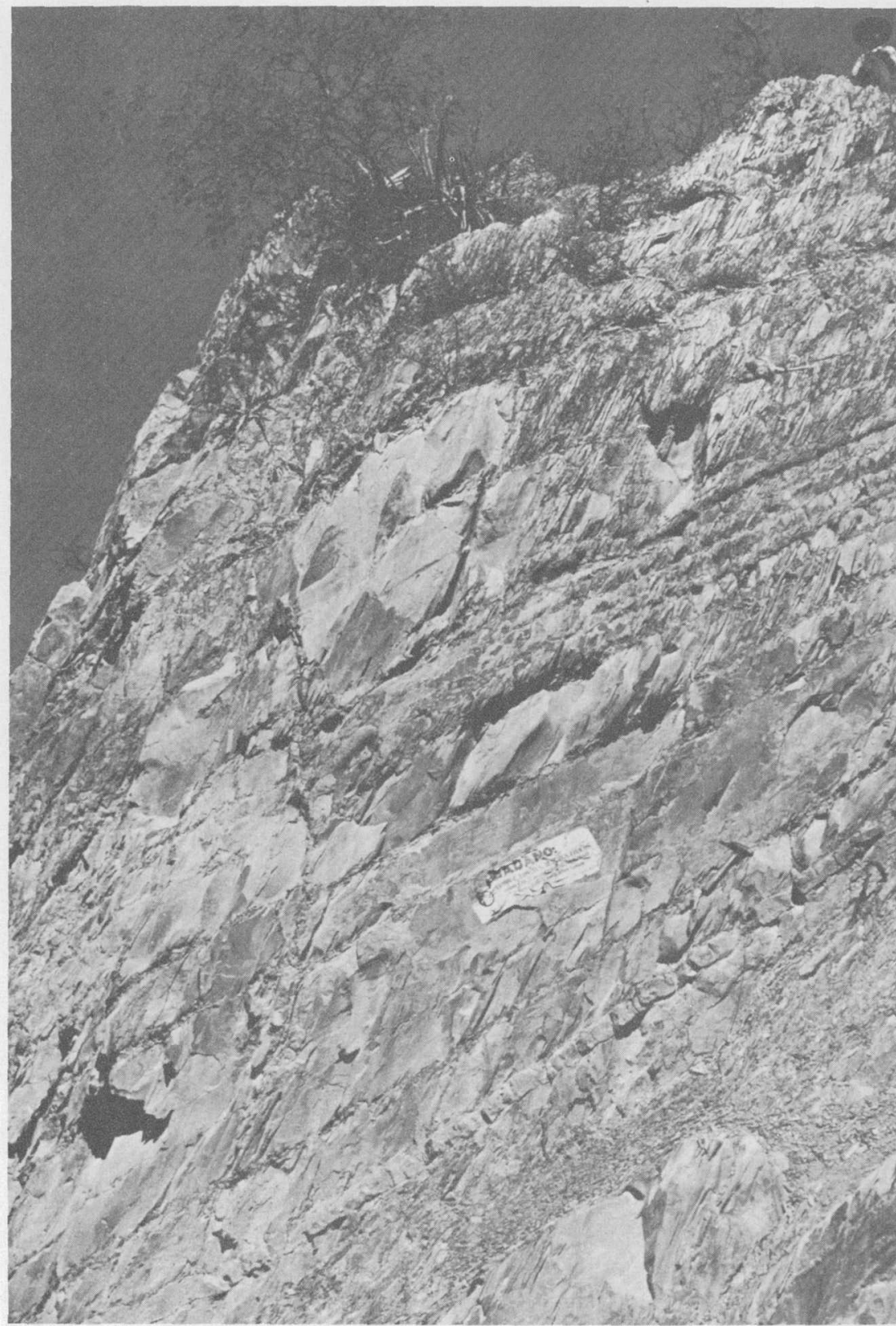

Figure 57. - Fracture cleavage in marl of the Méndez formation near Los Venados, Hidalgo. 


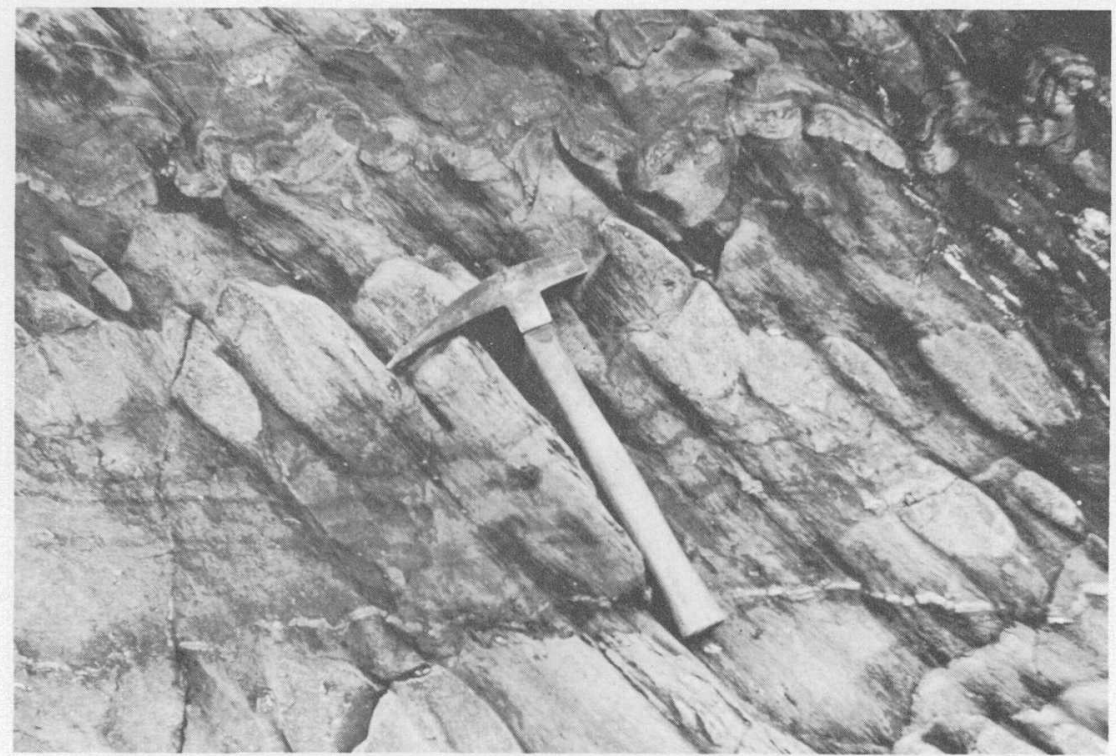

Figure 58.-Eroded surface of El Doctor limestone northeast of Zimapán, Hidalgo, showing fracture cleavage dipping $45^{\circ}$ and nearly horizontal undulating bedding.

No true overthrusting like that described above was observed in rocks of Cenozoic age within the area, but apparent reverse faults with steep dips were seen in the Sierra de Pachuca. The reverse movement is probably due to differential gravity movements of adjacent fault blocks rather than to the action of a compressive force.

\section{NORMAL FAULTS}

Numerous normal faults cut strata of both Mesozoic and Cenozoic ages (fig. 60), but most of them are too small to be plotted at a $1: 100,000$ scale and hence are not shown on plate 3 ; the few faults that are shown are major ones. Many of the faults that cut rocks of the Pachuca group and older strata are occupied by dikes and veins. Distribution of the faults appears to be irregular; both the PachucaReal del Monte and the Zimapán districts are seemingly areas of intensified faulting as compared with adjacent areas.

The dominant orientation of normal faults throughout the entire area is between east-west and southeast-northwest. In Real del Monte and northward a few kilometers, there is a northward-trending system of faults, apparently younger than the eastward-trending system, because it does not contain dikes as the latter system does. In the Zimapán district "the larger faults have a northwestward trend and are cut by a subsequent group of northeastward-trending minor faults" (Simons and Mapes, 1956, p. 34). 


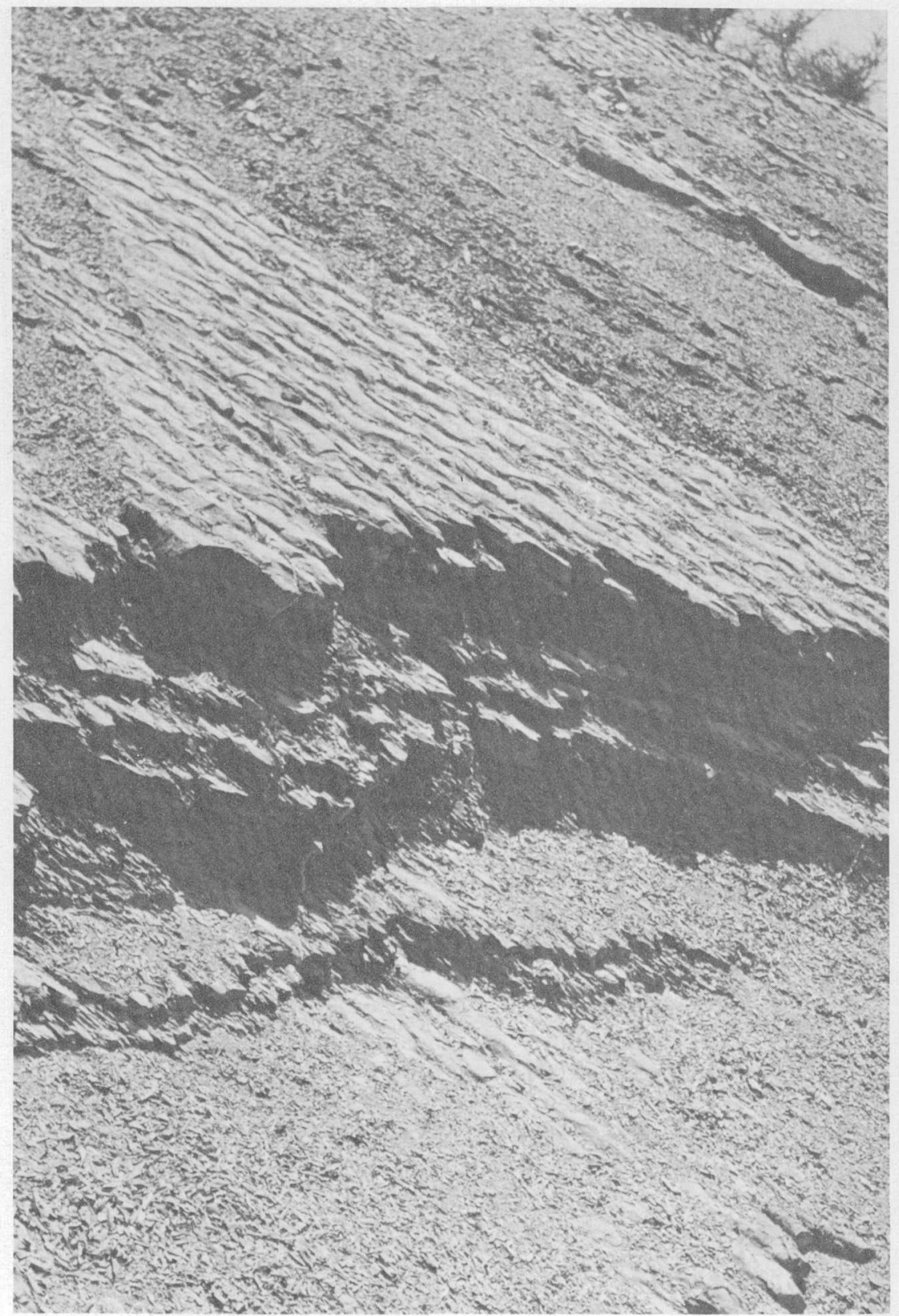

Figure 59.-Ripplelike expression of fracture cleavage in shale beds of the Mexcala formation on the south slope of Cerro Tunitilán, $2 \mathrm{~km}$ northwest of Mixquiahuala, Hidalgo. 


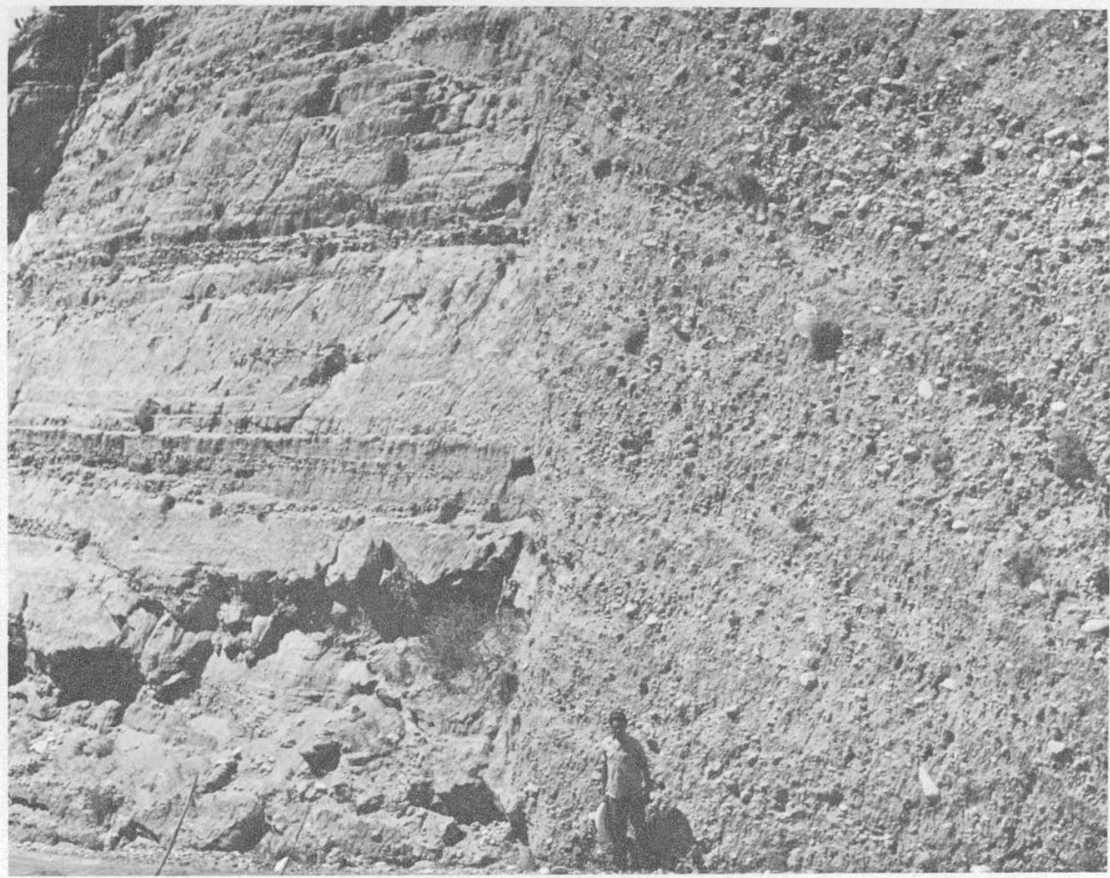

FIgure 60.-Coarse gravel faulted against interbedded silt, sand, and gravel of the Tarango formation at Cuesta de Texquedo, $6 \mathrm{~km}$ northwest of Tasquillo, Hidalgo.

The displacements are unknown except in the Pachuca-Real del Monte mining district, where a network of mine workings facilitates the study of movement along faults. Dip-slip movement of as much as $300 \mathrm{~m}$ and more was measured near Pachuca. An escarpment of El Doctor limestone extends from 12 to $20 \mathrm{~km}$ east of Ixmiquilpan; this feature appears to be a fault scarp, and its height $(150-350 \mathrm{~m})$ is a measure of the displacement of beds. Another large fault is located $131 / 2 \mathrm{~km}$ northeast of Actopan. Beds of El Doctor limestone on the northeast side of this fault lie as much as $200 \mathrm{~m}$ above volcanic rocks of the Pachuca group immediately to the southwest.

Normal faulting was probably repeated during Cenozoic time, for the oldest Tertiary rocks are more strongly tilted than younger rocks whose dips are progressively less steep upward in the section.

\section{JOINTS}

Steeply dipping and vertical joints occur in both the thick-bedded El Doctor limestone and the andesite flow rock of the Pachuca group. The joints are randomly oriented, and though they are more or less uniformly spaced at a given locality, there is no pronounced columnar 
jointing in the area. The spacing ranges from about $10 \mathrm{~cm}$ to 1 or 2 m. Commonly a given joint plane extends through the entire thickness of a limestone bed or a lava flow. Joint planes in flat-dipping limestone may extend through several beds, but joint planes in lava end at the top and bottom of each flow. In some flows the steep joints are intersected by flat-dipping joints, and weathering and erosion along them produce spheroidal or orbicular forms. Solution weathering has enlarged the joints in limestone.

\section{GEOMORPHOLOGY}

Landforms in the area are of three major types: erosional forms in rocks of Mesozoic age, erosional forms in rocks of Cenozoic age, and surfaces of basin-fill deposits. The erosional forms in rocks of Mesozoic and Cenozoic age are of a great variety, which is determined by the lithology and structure of the underlying rocks and by the local stage of the erosion cycle. The major rivers are actively eroding the basin-fill deposits; the streams have removed enormous volumes of the fill material by down cutting and by stream capture. The present epoch, though primarily one of dissection, locally, is also one of deposition.

\section{EROSIONAL FORMS IN ROCKS OF MESOZOIC AGE}

In the northern and eastern parts of the area of plate 3 , broad valleys and mountain valleys are underlain by the Las Trancas, Soyatal, of Mexcala-Méndez formations, whereas the topographic highs are typically underlain by the El Doctor formation. The major streams usually form broad valleys in the marine clastic beds and narrow gorges in the limestone. Examples of these relations are (a) $10 \mathrm{~km}$ west-northwest of Atotonilco el Grande, where the Río Amajac leaves the broad valley of Santa María to plunge into the Cañón de las Dos Peñas, (b) $31 \mathrm{~km}$ northeast of Ixmiquilpan, where the Río Tonaltongo leaves a valley in Méndez shale to enter a gorge in El Doctor limestone, and (c) $16 \mathrm{~km}$ east of Zimapán, where the Barranca del Salitre leaves a valley in the Las Trancas formation near Adjuntas de San Pablo and enters a canyon in the El Doctor limestone. Slopes in the marine clastic beds are typically dissected by closely spaced gullies, whereas those in the limestone tend to have a more widely spaced drainage pattern.

The topographic lows usually coincide with synclines, but they also tend to occur where anticlines have been breached through to the Las Trancas formation. Much of the high topography in the El Doctor limestone is along the axes of anticlines. Between Ixmiquilpan and Actopan, high anticlinal ridges of limestone to the north 
give way to lowlands to the south at the places where the fold axes plunge southward.

Solution weathering and erosion of the El Doctor and Cuautla limestones have produced some of the features of karst topography, particularly in the Ixmiquilpan bank. Grutas de Xoxafí and Grutas de Tonaltongo, caves $22 \mathrm{~km}$ east-southeast and $29 \mathrm{~km}$ northeast of Ixmiquilpan, respectively; were formed by solution weathering of the bank facies of the El Doctor limestone. A large spring, emerging as a full-fledged river from the Tonaltongo cave, subterraneously drains a vast highland area that lies south of the cave. Surface drainage of this highland area is into the Río Tula, but the Tonaltongo spring drains into the Río Amajac: Debodé dam, built in limestone of the Ixmiquilpan bank $11 \mathrm{~km}$ east of Ixmiquilpan, failed because of leakage through solution channels in the bedrock.

Sinkholes are rare not only because erosion of the bank-forming limestone is at a mature stage of the cycle but also because lower parts of the limestone surface are covered by deposits of Cenozoic age. A collapsed sink $400-500 \mathrm{~m}$ in diameter and $60 \mathrm{~m}$ deep occurs $22 \mathrm{~km}$ east-northeast of Ixmiquilpan, and another collapsed sink 250 $300 \mathrm{~m}$ in diameter and 15-20 $\mathrm{m}$ deep is in the northwest part of the town of Apaxco. Both of these depressions are in the Tarango formation, where collapse of the clastic sediments was caused by the formation of sinkholes in the underlying El Doctor or Cuautla limestone.

Widespread distribution of outcrops of the El Doctor limestone and also their certainly wider distribution before the area was largely covered by volcanic debris and other fill materials of Cenozoic age suggest that solution of the limestone may have affected the evolution of major stream courses in other ways than by formation of purely local karst features. In places, major streams cross the structure of folded rocks of Mesozoic age in such a manner as to suggest that the streams were superposed from a Tertiary cover. However, the Río de Los Griegos follows an underground course in the El Doctor limestone at a place called Puente de Dios, $12 \mathrm{~km}$ west of Atotonilco el Grande; and northwest of the area here discussed, the Río Jalpan follows a tunnel through a limestone ridge at another "Puente de Dios". At both places the roof will very likely ultimately collapse and both major streams will then appear to have been superposed upon the rock structure. Possibly some streams, now following narrow valleys through limestone ridges, may have achieved their present position by similar evolution of underground drainage and later roof collapse. Such a process may also have taken place elsewhere in the southern part of the State of Hidalgo and the northern part of the State of México, where a volcanic cover now exists and where limestone ridges and the stream valleys through them are now buried. 


\section{EROSIONAL FORMS IN ROCKS OF CENOZOIC AGE}

Major landforms in the rocks of Cenozoic age are high mountain ranges that extend to more than $3,000 \mathrm{~m}$ above sea level. Maturely eroded summit areas dotted with pinnacles of resistant volcanic rock characterize the Sierra de Pachuca and the Sierra de Juárez (fig. 61).

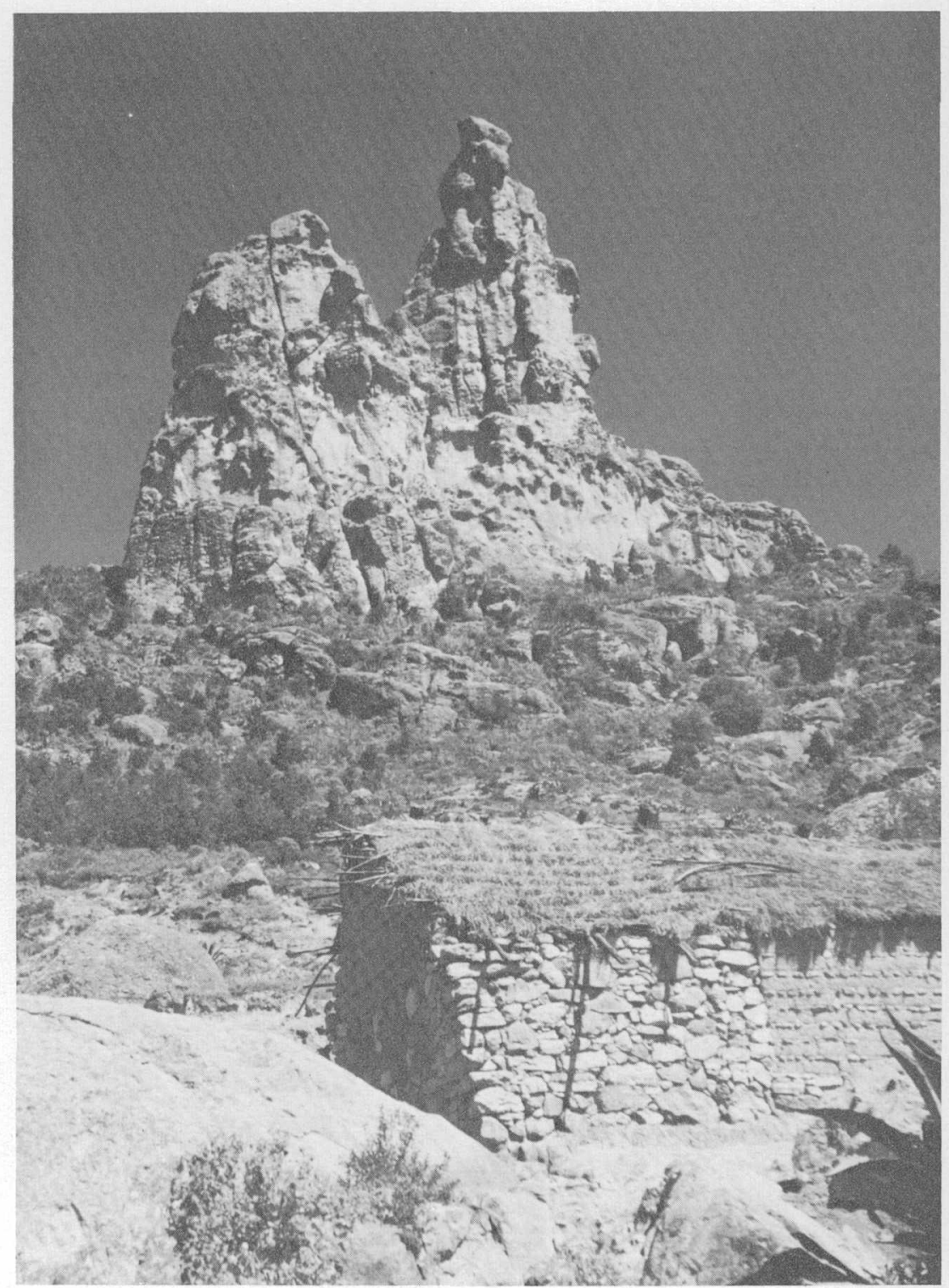

FIgURE 61.-Los Frailes, resistant pinnacles of dacite at the crest of the Sierra de Pachuca. 
Gently rolling ground at the crest of the Sierra de Pachuca is encroached upon by youthful gullies, and numerous cliffs are cut in the sides of the mountain range. The Sierra de Juárez and the Sierra de Xinthé are more uniformly eroded from top to bottom. No constructional forms are preserved in the cliff-forming El Morro group or in volcanic rocks that are older than the San Juan group.

\section{SURFACES OF BASIN-FILL DEPOSITS}

The lowlands are covered in large part by unconsolidated clastic deposits. Several surfaces extending for great distances over the lowlands are the result of the blocking of drainage basins by volcanic action or by faulting and partial filling of the basins with sediments. The flat areas at different levels and in different watersheds include the Actopan, El Tablón, Chilcuautla, Zoquital, and Florida surfaces.

Clastic deposits of the Tarango formation underlie extensive plains between Actopan and Tula and between Actopan and Puerto de Pastores. A similar flat constructional surface is that of the Mexico Basin, which extends southwestward from Pachuca and is thickly covered with clastic deposits of Quaternary age. Stream dissection has removed most of the clastic materials north of Puerto de Pastores and has carved the remnants into buttes and terraces. At Actopan the altitude of the practically undissected surface is $1,990 \mathrm{~m}$ above sea level. The terrace levels at Puerto de Pastores and at the top of Cuesta de Texquedó, an escarpment of sand and gravel nearly $400 \mathrm{~m}$ high located about $15 \mathrm{~km}$ south-southeast of Zimapán, are also. just under $2,000 \mathrm{~m}$ above sea level. It is here proposed to call the surface at that level the Actopan surface. This surface rises gradually southward and southeastward to over $2,100 \mathrm{~m}$ and is everywhere $50-150 \mathrm{~m}$ higher at the outer edges than it is in the middle.

Two lower surfaces, partly covered by thin lava flows, occur along or near the Río Tula south of Ixmiquilpan at about $1,900 \mathrm{~m}$ and $1,850 \mathrm{~m}$ above sea level and correspond to $Q_{2}$ and $Q_{3}$ of the Quarternary basalt series. $Q_{1}$ is on, or slightly below, the Actopan surface. It is proposed here to name these surfaces El Tablón (fig. 62) and Chilcuautlá, respectively.

Similar constructional surfaces, which have been partly dissected to form broad terraces, lie between Atotonilco el Grande and Zoquital at an altitude of about $2,100 \mathrm{~m}$ above sea level, and in the vicinity of Florida, Hidalgo, at about $1,900 \mathrm{~m}$. It is proposed here to name these surfaces Zoquital and Florida. The Zoquital surface is mostly covered by basalt of the Atotonilco el Grande formation, but there is no lava cover on the Florida surface, which is underlain by sediments of the Tarango formation. 


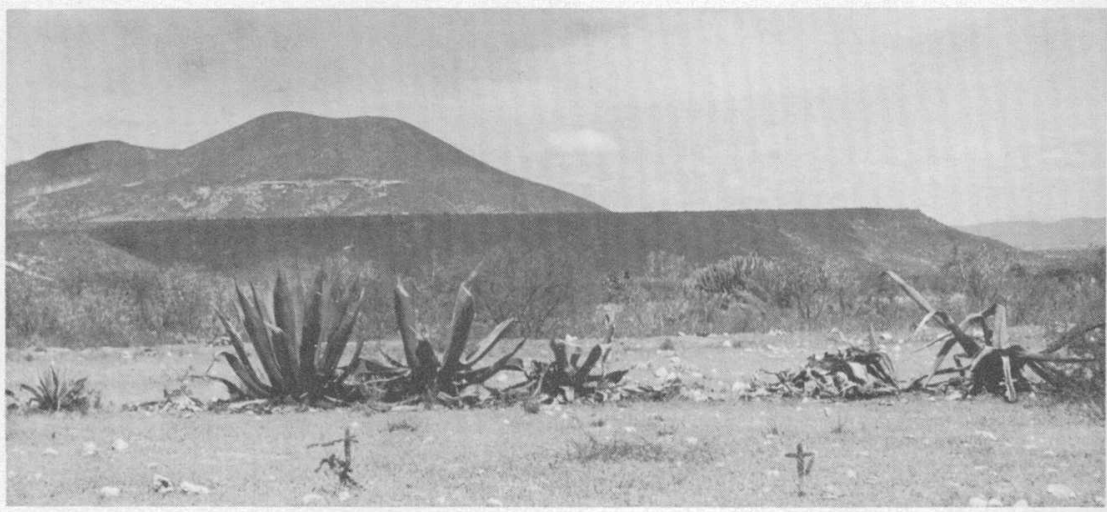

FIgURE 62.-The terraced El Tablon surface (in shadow) and a small remnant of the higher Actopan surface (light-colored streak on distant hillside) near Ixmiquilpan, Hidalgo.

\section{SUPERPOSITION OF STREAMS}

An old surface of considerable relief was buried by the basin sediments. The area from Actopan and Cuesta de Texquedó, a distance of $55 \mathrm{~km}$, is drained by the Río Tula and its tributaries, which cross ridges and valley shoulders of the old surface as well as broad lowlands. The Tula itself cuts no less than three ridges of volcanic rock that divide broad lowland areas into four separate valleys: those of Alberto, Ixmiquilpan, Tasquillo, and Oquintahá. The cuts through these ridges are deep, narrow, steep-walled canyons whose upper rims are not, however, as high as the Actopan surface (fig. 63). The anomalous course of the present Río Tula and its large tributaries across partly exhumed valleys and rock ridges of the old topography is explained best by superposition or letting down of the drainage pattern, first established on the flat surface of a basin fill, onto a buried topography consisting in part of resistant ridges.

A patch of ground covered with angular blocks of basalt and with gravel consisting of well-rounded pebbles of andesite, shale, and limestone lies northwest of Tecomates, Hidalgo, or near the place where the northward flowing Río Amajac leaves the area of plate 3. This ground seems to correspond to a topographic low in the old surface that was covered by the Atotonilco el Grande formation. The present course of the river east of the patch is through a limestone gorge whose rim is higher than the gravel and basalt, or apparently in the east shoulder of the ancestral valley.

South of Plomosas, 15-20 km west-northwest of Atotonilco el Grande, the Río Amajac and a tributary, Arroyo de los Naranjos, have cut gorges in El Doctor limestone terrain whose top altitudes are higher than those of younger volcanic terrain immediately to 


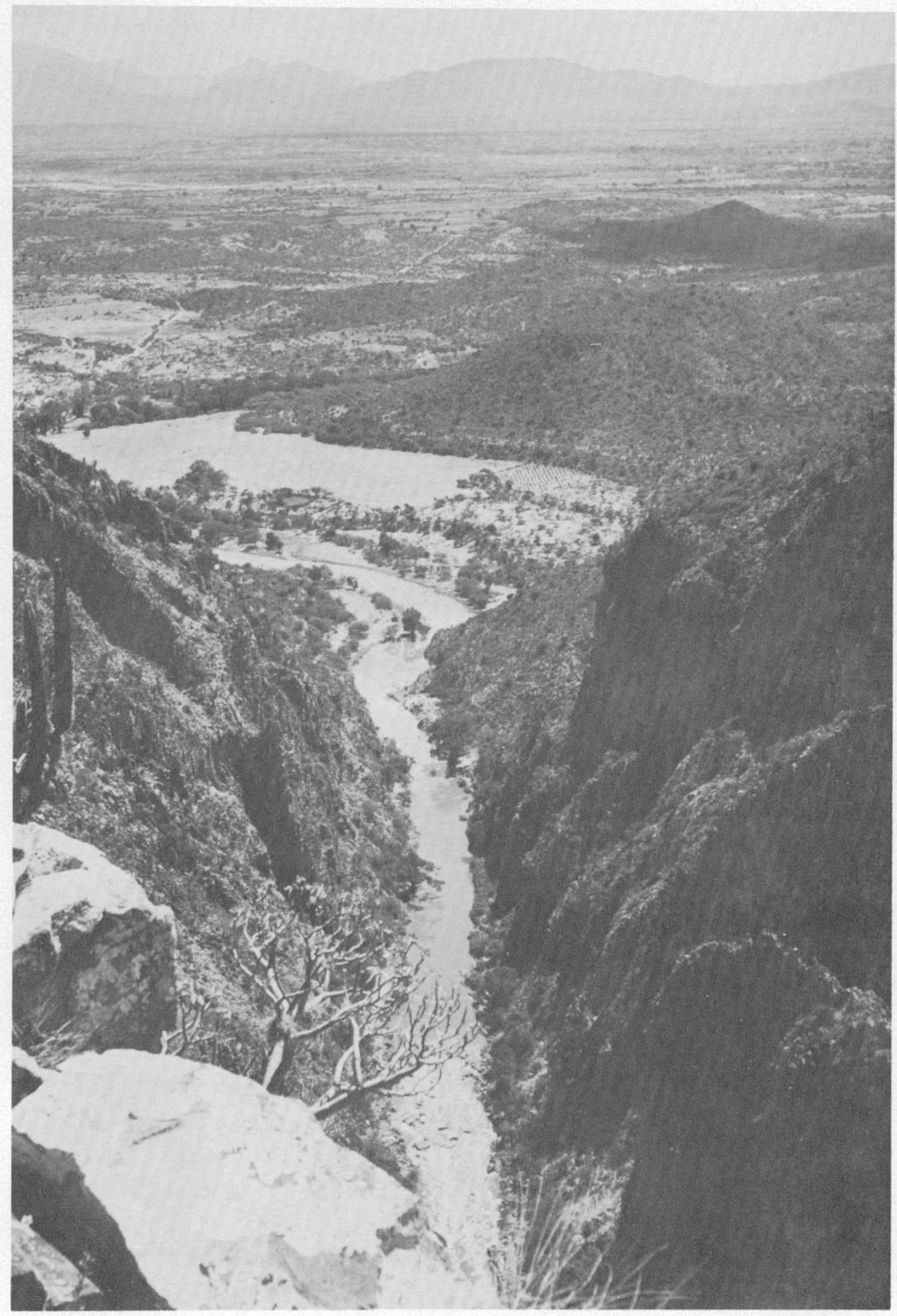

Figure 63.-View up the Río Tula from the rim of Cañon del Abra to the broad plain of the Ixmiquilpan valley. Cañon del Abra lies between the Ixmiquilpan and Tasquillo valleys. 
the south and southwest. The valley-shoulder courses of the Río Amajac and Arroyo de los Naranjos at the sites of figures 64 and 65

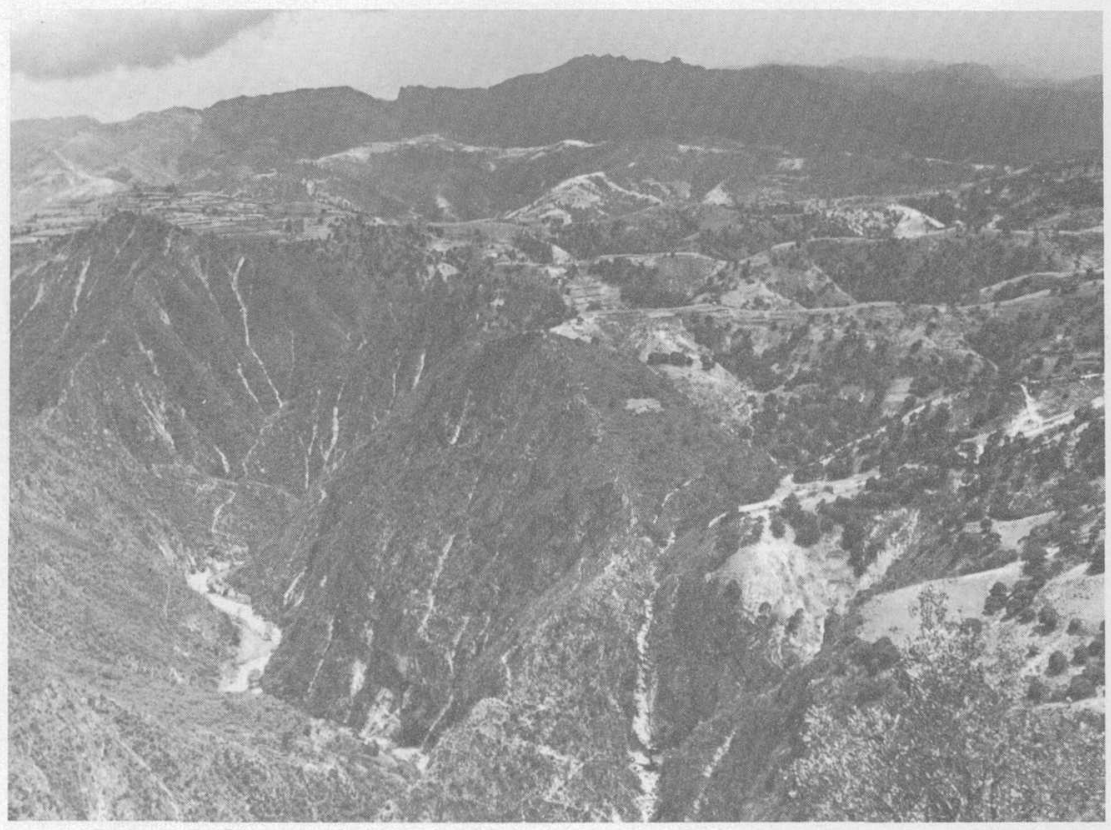

Figure 64.-View south-southeast from Plomosas, Hidalgo, showing gorge of the Río Amajac cut in El Doctor limestone in the shoulder of an ancient valley. The deeper parts of the ancient valley are occupied by younger rocks (right).

clearly indicate stream superposition from a volcanic cover that was partially removed by erosion.

Near Los Venados, Hidalgo, in the northeast corner of the area of plate 3, the present course of the Río Metztitlán is through a gorge carved deeply in shale of the Méndez formation, yet the parallel course of Arroyo del Potrero Seco to the east is through a valley almost equally deep in the Atotonilco El Grande formation. The present course of the arroyo corresponds to a topographic low in the old shale topography, whereas that of the main river is cut in the west shoulder of the ancestral valley. The courses of the present Río Amajac and Río Metztitlán in valley shoulders of the old topography result apparently from their superposition from andesite of the Pachuca group or from basalt flows and basin-fill sediments of the Atotonilco El Grande formation.

Other superposition of drainage may have occurred in the more remote past, for the present drainage of limestone and shale terrain in the northern part of plate 3, though subsequent in part, is in 


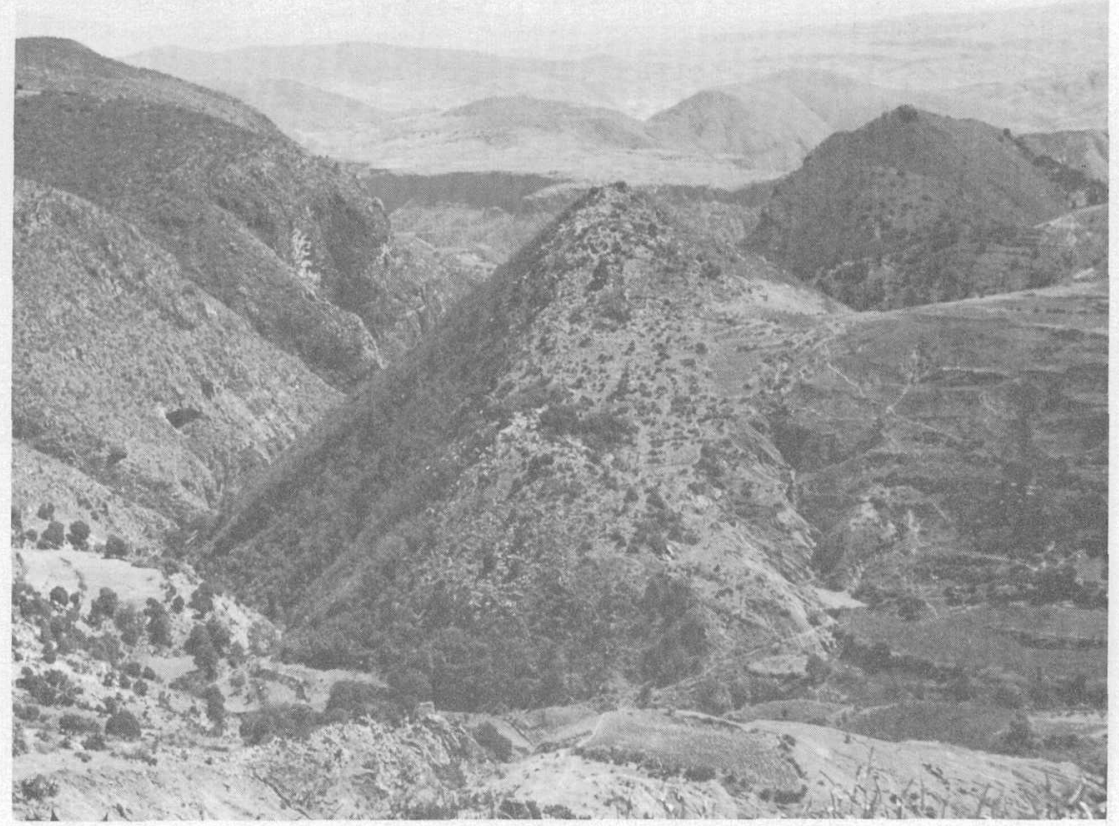

Frgure 65.-View southeast from Escuela Plomosas, showing gorge cut in El Doctor limestone by Arroyo de los Naranjos in the shoulder of an ancient valley. The ancient valley is partly filled with andesite of the Pachuca group (right), which is less resistant to erosion than the limestone (left).

places anomalously across folds in rocks of Mesozoic age. The Río Tolimán north of Zimapán may have been superposed from a cover of now-eroded Tertiary rocks (Simons and Mapes, 1956, p. 35). Patches of volcanic cover north and northeast of the dominantly Cenozoic terrain of plate 3 are evidence that a more complete Tertiary cover existed in the past, though it was stripped away almost completely, and the crosscutting stream courses are a result of superposition from such a cover.

\section{DOWNCUTTING AND STREAM CAPTURE}

Once the ancient ridge tops were exhumed in the present Río Tula drainage area, denudation of the Tasquillo, Ixmiquilpan, and Alberto valleys became a separate process in each of the lowland units. Local base-level control consists of the bedrock gorges that separate the valleys, for in each gorge there are one or more rapids that represent places of local steepening or knickpoints in the long profile of the river. The uppermost knickpoint is the local temporary base level for erosion of the valley upstream. As long as the knickpoint remains effective, the base level stays the same, and easily removed basin sedi- 
ments of valley lands tend to be flushed out to that level. Thus an erosion surface is formed which, through subsequent lowering of the base level, becomes a cut terrace. The present surface of the Ixmiquilpan valley, made up of broad, poorly defined cut terraces at 1,700 $\mathrm{m}$ to over $1,800 \mathrm{~m}$ above sea level, is cut by vertical-walled gullies 4-10 $\mathrm{m}$ deep that are graded to the latest knickpoint in Cañón del Abra (fig. 66). The El Tablón and Chilcuautla surfaces are better defined

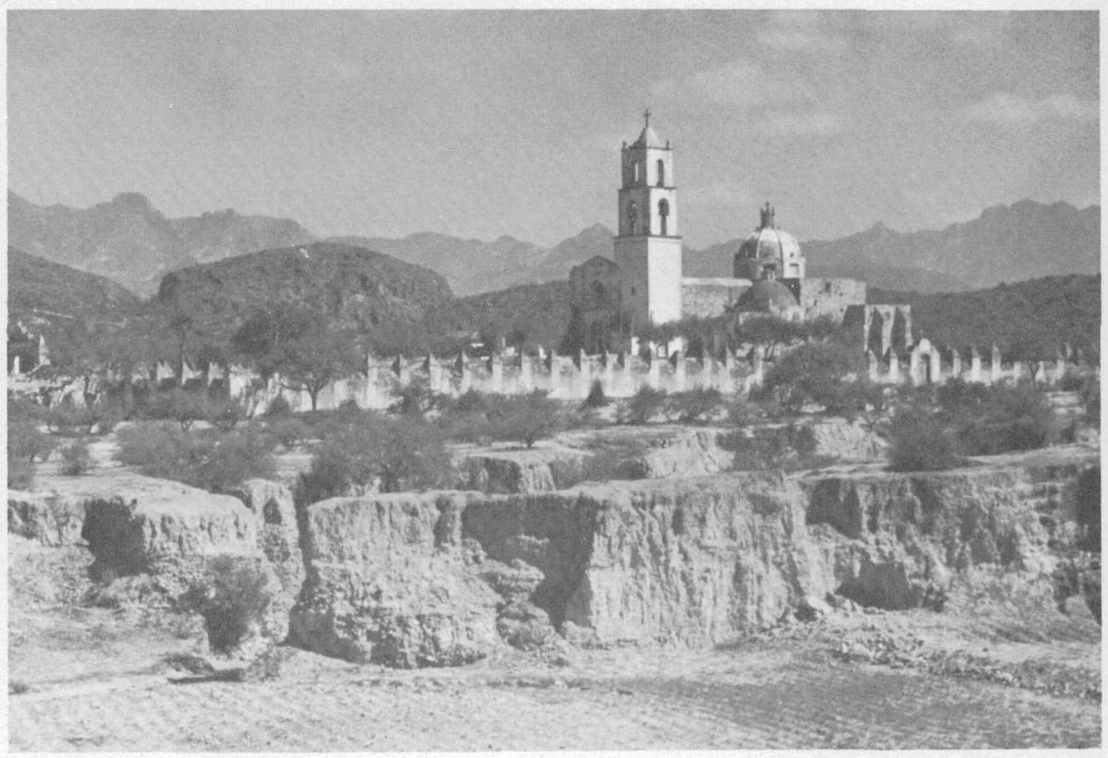

Figure 66.-Gully cut in Recent sediments in the Ixmiquilpan valley at San Juaníco, Hidalgo.

than other intermediate terrace levels, because they have been preserved in lava which descended stream channels cut in the basin sediments.

Vigorous downcutting by streams is proceeding practically everywhere in the region, even on slopes of the closed drainage area of the Mexico Basin. Inasmuch as the streams with the steepest gradients are the most vigorous cutting agents, capture of parts of the drainage areas of less vigorous streams has taken place in the recent past or is imminent today. The Río de Los Griegos, a tributary of the Amajac that heads about $12 \mathrm{~km}$ northeast of Pachuca, has cut through the crest of the Sierra de Pachuca from north to south and captured drainage of the Río Actopan, a tributary of the Tula. From Puerto de La Palma near its head to its junction with the Amajac $15 \mathrm{~km}$ to the north, the Río de Los Griegos falls about 1,000 m, whereas the corre- 
sponding headwater stream of the Río Actopan falls less than $500 \mathrm{~m}$ from Puerto de La Palma to a point $15 \mathrm{~km}$ downstream. Similarly, the Río de Tonaltongo, another tributary of the Amajac, seems to be capturing a drainage area of the Río Tula northeast of Ixmiquilpan.

The Mexico Basin probably provides today a picture of what the areas of the present Tula and Amajac-Metztitlán drainage system were in the past, before they were captured by exterior drainage channels, because this basin is still untapped except for artificial drainage through an open cut and two tunnels in the northern watershed divide. The floor of the basin is flat and uneroded, except where the artificial cut called Tajo de Nochistongo has locally lowered the base level.

\section{RECENT DEPOSITION ALONG STREAMS}

There are a few places in the region in addition to the Mexico Basin where deposition is taking place more rapidly than erosion. Talus piles accumulate at the base of cliffs and partly fill narrow upland valleys in rugged sections of the Sierra de Pachuca, where they allow seepage through the permeable material below the surface. Along the steep-sided asymmetric valley of Pechuga that extends northward from the rugged Sierra de Juárez, the fill on the west side of the valley is much longer than that on the east. The valley is floored with thick talus and bouldery fanglomerate whose surface slopes eastward, apparently because most of the detrital material is derived from the west. A strong, perennial stream in Barranca de Pechuga flows underground for about $3 \mathrm{~km}$ through this deposit.

Because of the large size of its drainage basin and the lack of a protective cover of vegetation over it, the valley of the Río Metztitlán is subjected to the largest floods that occur within the area mapped. Many hectares of orchards and cultivated fields in the region of Los Venados were covered by silt and sand brought down by floods in 1954 and 1955. Figure 67 shows part of the Metztitlan valley before the floods, and figure 68 shows the same part after the floods.

Many of the clastic deposits that are being laid down today are quickly removed. Figures 67 and 68 show that a new channel was cut by the Río Metztitlán in its recent flood deposit. Alluvium is deposited by active streams, and then it is partially eroded or removed altogether during the course of a single storm. Alluvial fans are formed where gullies emerge from the Sierra de Xinthe and other mountain ranges, and then the fans are dissected; a whole cycle of deposition and erosion takes place within a few years. The Otomí Indians have used their knowledge of stream erosion and deposition in building closely spaced rock dams across the gullies of deeply dissected areas and planting their crops on the fill above the dams. 


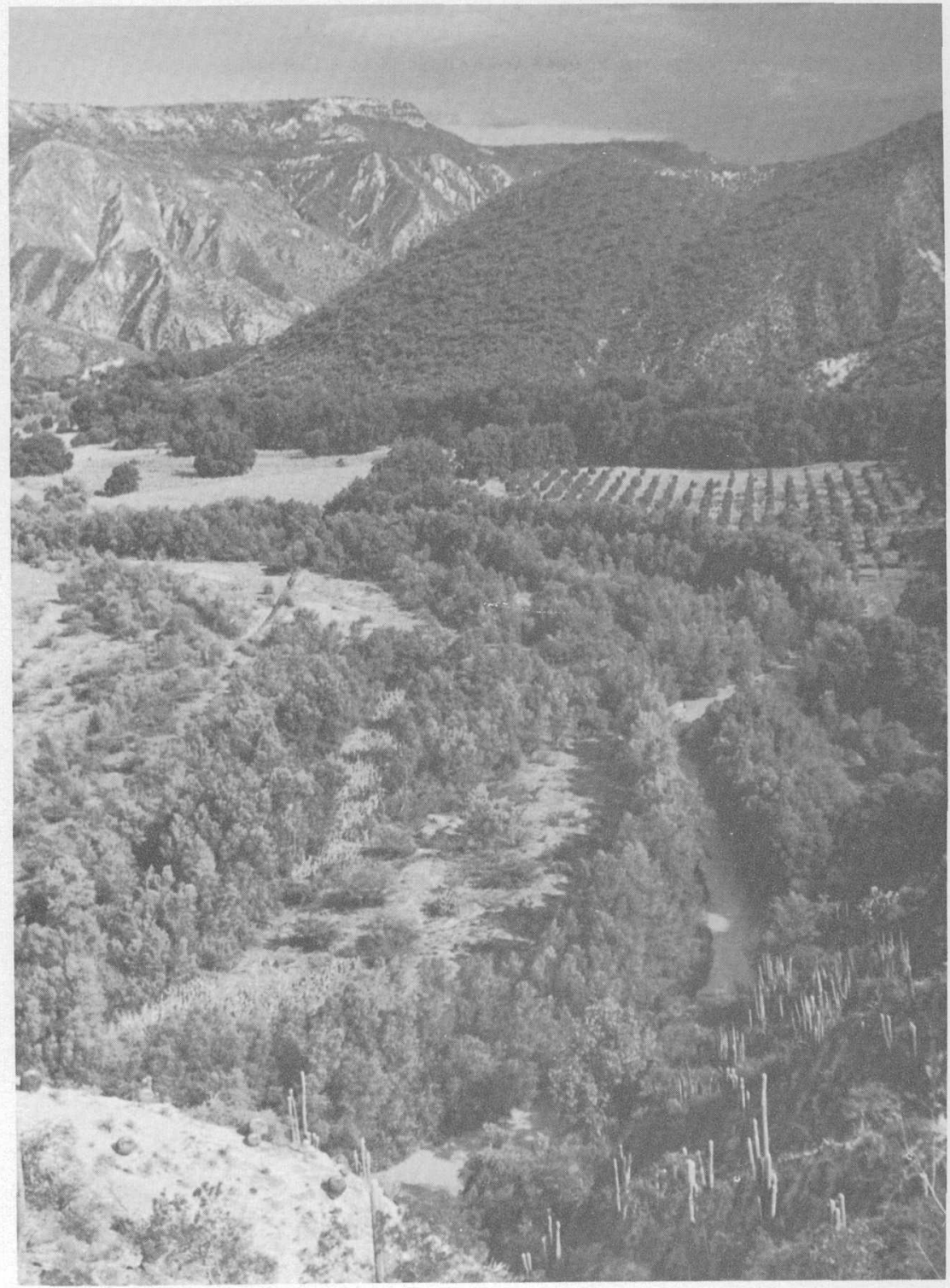

Figure 67.-Valley of the Río Metztitlán, looking upstream from near Los Venados, Hidalgo. Photographed in June 1954.

\section{GEOLOGIC HISTORY}

Predominantly clastic marine sediments were deposited during the late Kimmeridgian and Portlandian stages of Late Jurassic time in a sea whose shore lay about $50 \mathrm{~km}$ west of Puerto de Las Trancas, at the longitude of Bernal, Querétaro. 


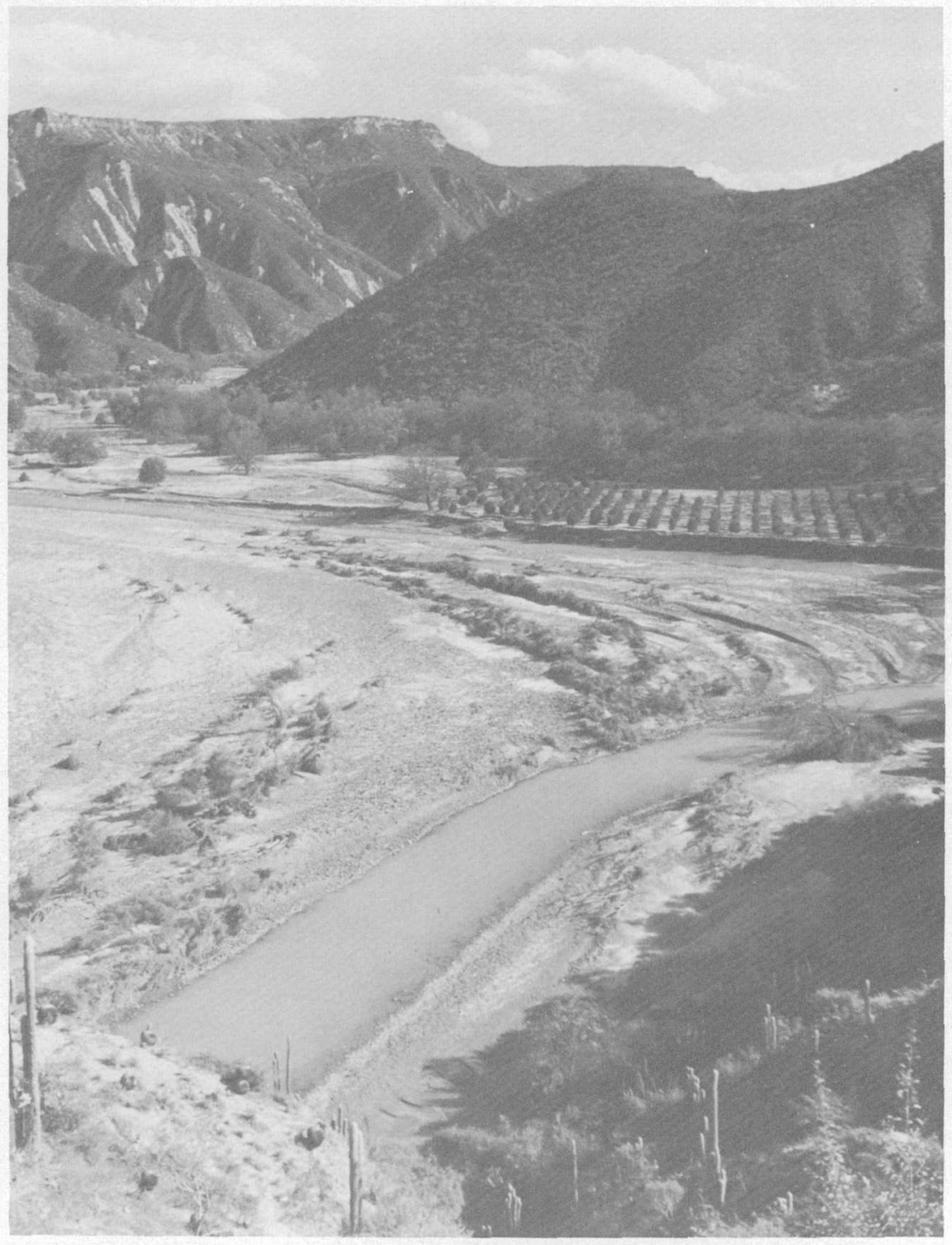

Figure 68,-Valley of the Río Metztitlán. The same view as that of figure 67, but photographed 2 years later, in May 1956; note results of the floods of 1954 and 1955.

The sea receded in Early Cretaceous time, so that during part of the Neocomian stage the shoreline was a few kilometers east of Puerto de Las Trancas, and clastic beds and impure limestone were deposited at the longitude of Santuraio, Hidalgo. The sea continued to retreat eastward, and almost certainly during the Aptian stage, possibly also during the early part of the Albian stage, the shoreline lay east 
or northeast of the area mapped. The shallow Cretaceous sea transgressed $100 \mathrm{~km}$ or more inland later in the Albian stage, and an area extending as far west as the State of Guanajuato received calcareous deposits, locally including reefs, during the rest of Albian and all or part of Cenomanian time.

A long northward-striking seaway existed in Turonian time. Relatively pure limestone and calcarenite were deposited in a rather narrow zone in the middle of the seaway, and argillaceous limestone and clastic sediments in broader zones on either side. The entire region was covered by seas in Coniacian (?) or Campanian (?) time and probably during the early Maestrichtian stage. Since then, all the southwestern part of the State of Hidalgo and the northeastern part of the State of México have been emergent.

The emergence was a result of the Laramide orogeny, which ended well before latest Eocene time, inasmuch as the lacustrine deposits of Eocene age at Cuesta del Chiflón are not folded. During the orogenic period the rocks of Mesozoic age were folded and faulted. High relief of the land caused rapid erosion and the deposition of very coarse clastic material in basins to form the El Morro conglomerates. Extrusion of lavas ranging in composition from basalt to rhyolite (the Pachica group and Geyne's Cerezo rhyolite) was accompanied by extensive block faulting. Toward the end of the Miocene epoch, quartz veins, some of which were mineralized, formed in Mesozoic rocks.

Late Tertiary orogeny began during the Pliocene and resulted in uplift and in the extrusion of the Zumate and Tezuantla decite lavas and the Don Guinyó tuff. The streams were rejuvenated and there was increased erosion, which caused the overloading of some streams and the local blocking of drainage by alluvial fans in the plateau country. Rivers that were not blocked were able to maintain their courses and hence became antecedent streams. Volcanic conglomerate and tuff were deposited by mass movements and by torrential mountain streams near the present Tasquillo, Hidalgo, during the middle(?) Pliocene epoch. Extrusion of the basaltic lavas of the San Juan group began. As uplift continued and base level was further lowered, erosion of the coarse clastic materials and basalt lava set in; this erosion cycle progressed to the stage of maturity before drainage of the present Tula and Amajac-Metztitlán rivers was blocked by faulting or volcanism in the late(?) Pliocene.

A period of relative crustal stability followed, during which the blocked-drainage areas received the Tarango and Atotonilco el Grande sediments and basaltic laval flows; these buried maturely eroded hills and ridges of volcanic and marine sedimentary rocks. Most of the areas between Pachuca and Zimapán and between Atotonilco el 
Grande and Tecamates, except for major mountain ranges, were covered by clastic sediments or basalt lava. Mature drainage systems formed in other areas, along with local production of karst topography in limestone terrain.

The area attained its present altitude during Pleistocene time. Volcanism closed the Mexico Basin to the south, but rejuvenation of the erosion cycle, due to the uplift, caused freeing of blocked drainage areas to the north by the Tula, Amajac, and Metztitlán rivers, which were superposed through a cover composed of the Tarango and Atotonilco el Grande formations. Local formation of karst topography continued, perhaps at an accelerated rate. As uplift continued, excavation of the soft cover deposits progressed and the ancient topography of middle Pliocene(?) time was exhumed. The larger streams, however, were well enough established to maintain their courses, and thus they carved narrow gorges in hard rock. Thin, highly fluid basaltic flows poured down successively lower levels of the Tula valley south of Ixmiquilpan, while basaltic cinder cones were built at eruptive centers in the southern part of the area mapped.

Today, deeply incised streams of the region, through headward erosion, are tapping ever higher and more interior areas of trapped drainage and are integrating drainage of the karst areas. Meanwhile, sedimentation in the Mexico Basin has caused the floor to rise higher and higher until its present altitude (2,340 m above sea level) is only $45 \mathrm{~m}$ below the lowest pass in the watershed divide to the north.

\section{MINERAL DEPOSITS}

\section{METALS}

A belt of metalliferous mineral deposits about $100 \mathrm{~km}$ long extends northwest across the area from the Pachuca-Real del Monte silver mining district to the Zimapán lead-mining district, which lies a short distance outside the area of plate 3 . This belt is part of a larger mineralized zone extending northwestward from Zimapán, Hidalgo, across the entire State of Querétaro to Xichú, Guanajuato, and southeastward from Pachuca, Hidalgo, to Teziutlán, Pueblo. From Teziutlan to Xichú the strike is N. $58^{\circ} 30^{\prime} \mathrm{W}$. and the distance is 320 $\mathrm{km}$. From southeast to northwest, the metalliferous mining districts within the area of plate 3 are: Pachuca-Real del Monte, Mineral del Chico, Capula-Santa Rosa, Magdalena, Plomosas, Cardonal-Providencia, Santuario-San Clemente, and Pechuga-Bonanza. Other deposits within the area mapped, but lying outside the main mineralized belt, include the veins at Chicavasco, those south of San Agustín Tlaxiaca, and those northwest of Tepeitic, three widely separated localities in the State of Hidalgo. 
All the known metalliferous deposits occur in the older rocks that range in age from Cretaceous to middle Tertiary. Without exception, Pliocene and younger rocks are completely barren of metalliferous deposits. Northeast of the main mineralized belt, the broad outcrop area of rocks of Mesozoic age is similarly barren of deposits. The belt of mineral deposits. lies roughly close to the northeastern edge of the Mexican Highland, which coincides approximately with the contact between Tertiary volcanic rocks and Mesozoic sedimentary rocks. All mineral deposits in the area occur either in volcanic rocks or in sedimentary rocks at or near contacts with volcanic rocks. Shallow-seated intrusive rocks occur near some veins. Deposits in sedimentary rocks are at no place more than a few kilometers distant from the outcrop of extrusive or shallow intrusive rocks. The smaller deposits cited above, which are in volcanic rocks, are as much as 40 $\mathrm{km}$ from this contact zone, however.

Ore deposits in the southeastern part of the mineralized belt, from Pachuca to Magdalena, have the following common characteristics: (a) They are in volcanic rocks of the Pachuca group, (b) they are epithermal deposits in veins and occur mostly as sulfides, (c) their most economically valuable ore is silver, but gold is also present in recoverable amounts (Flores, Teodoro, in Blasquez López and others, 1938 , p. 104), and (d) the veins are in steeply dipping normal faults that strike between west and N. $60^{\circ} \mathrm{W}$., except in a small zone just north of Real del Monte, where a north-trending system occurs in conjunction with the east-trending system. These characteristics are shared also by the scattered deposits west of the belt in the vicinity of Chicavasco, San Agustín Tlaxiaca, and Tepeitic, where west-northwest-trending veins in andesite of early to middle Tertiary age contain silver and lesser amounts of gold.

Most ore deposits in the northwestern part of the main belt from Plomosas to Pechuga-Bonanza are in the Las Trancas, Santuario, El Doctor, or Mexcala-Méndez formations. Several of the SantuarioSan Clemente mineral deposits, however, are in rhyolite or andesite of middle Tertiary age. The northern deposits vary widely in depth and shape. They include mesothermal, hypothermal, and pyrometasomatic types in veins, chimneys, and mantos, and they occur both as sulfides and as oxidized minerals. Lead and zinc are the principal metals, but silver is an economically important constituent of some of the northern bodies. At San Clemente the most valuable metal is yold. Some manganese ore has been found northeast and east of Plomosas (at Cerro del Petate and at Mesa de Doña Ana), and a small antimony deposit occurs at Oquintahá, Hidalgo, west of the belt. 
There is no vein pattern common to the Plomosas, Cardonal-Providencia, Santuario-San Clemente, and Pechuga-Bonanza districts. At Cardonal-Providencia the strike of the veins ranges from N. $70^{\circ} \mathrm{W}$. to $\mathrm{N} .10^{\circ} \mathrm{E}$., and at Pechuga-Bonanza there is a conjugate system of veins striking N. $80^{\circ}$ E., west, and N. $10^{\circ}$ E. (Flores, Teodoro, in Blásquez López and others, 1938, p. 115 and 123).

The explanations for alinement of the mineral deposits may be considered: (a) the alinement is related to the physiography; it extends along the edge of the Mexican Highland province, where the postmineral cover thins and disappears. The belt thus formed is a more likely place for ore deposits to appear at the surface than toward the center of the physiographic province, where the caprock is thicker. (b) The mineralization is related to a deep-seated intrusive mass from which the mineralizing solution came. The first hypothesis does not explain why the outcrop area of Mesozoic rocks northeast of the belt is barren; the second seems to be the more logical one. Numerous dikes and stocks, though of shallow-intrusive nature, suggest that the Pachuca-Real del Monte district may be underlain by a mass of deepseated igneous rock. Exposed bodies of monzonite in the Zimapán district and of granitic or dioritic rock in the Pinal de Amoles and Río Blanco districts northwest of the area are alined with the Pachuca district in a very general way and with most of the ore deposits. between those districts. However, ore mineralization in the other districts cannot be directly related to igneous activity.

The time of mineralization of the whole area, both southeast and north of the Pachuca-Real del Monte silver district, was probably the same, that is, toward the end of Miocene time or early in the Pliocene (A. R. Geyne and others, written communication). This age is in agreement with that postulated for the Zimapán mining district which lies just northwest of the area mapped (Simons and Mapes, 1956, p. 66).

Most of the production of metals in the area has been from the Pachuca-Real del Monte district, one of the principal silver-producing areas of the world. In four centuries of almost continuous exploitation the district has produced more than 31 million $\mathrm{kg}$ of silver and about $400,000 \mathrm{~kg}$ of gold (figs. 69 and 70). The Zimapán district produced about 15 million $\mathrm{kg}$ of lead and 15 million $\mathrm{kg}$ of zinc from 1945 to 1949 . Its total production of lead and zinc is unknown, but the total value of silver produced since mining began at Zimapán in 1632 is about $\$ 10$ million (Simons and Mapes, 1956, p. 1). The other districts in the area can be credited only with relatively small sporadic production (figs. 71 and 72). 


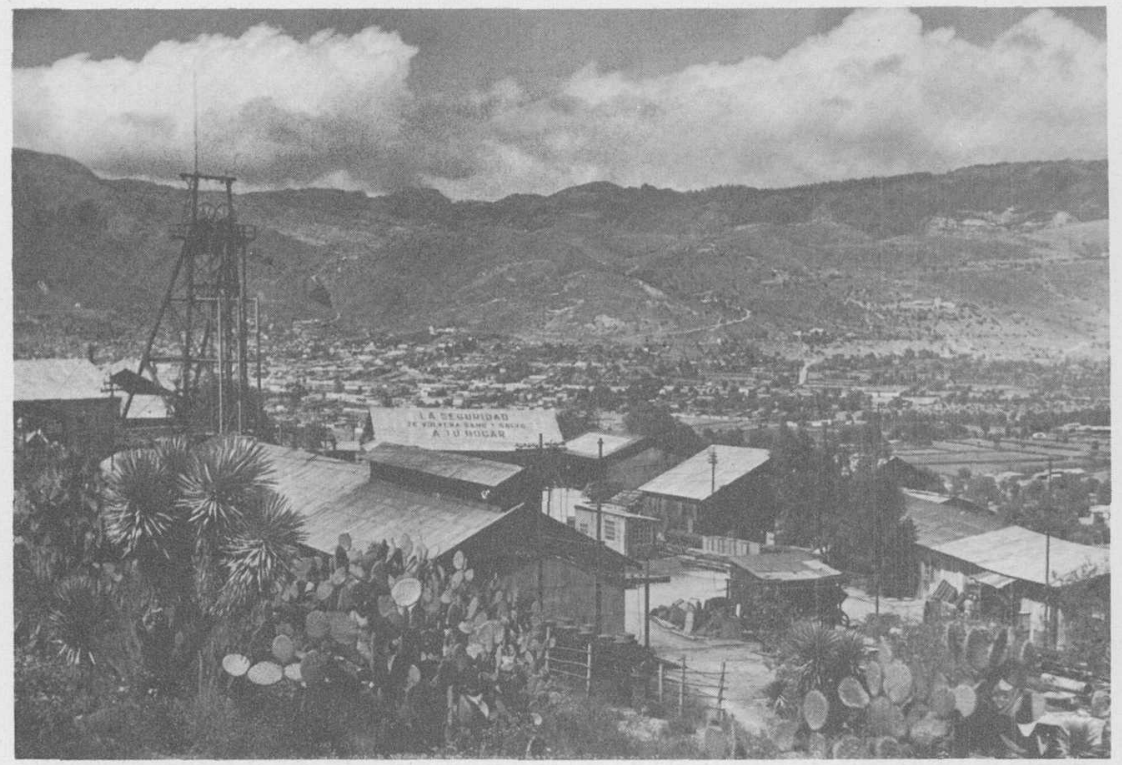

Figure 69.-Parícutin mine, a large-scale modern operating unit located $11 / 2 \mathrm{~km}$ southeast. of Pachuca, Hidalgo, on the east slope of Cerro de Cubitos.

The following table gives official production figures for the year 1954 (Secretaría de la Economia Nacional, Dirección de Minas y Petróleo) :

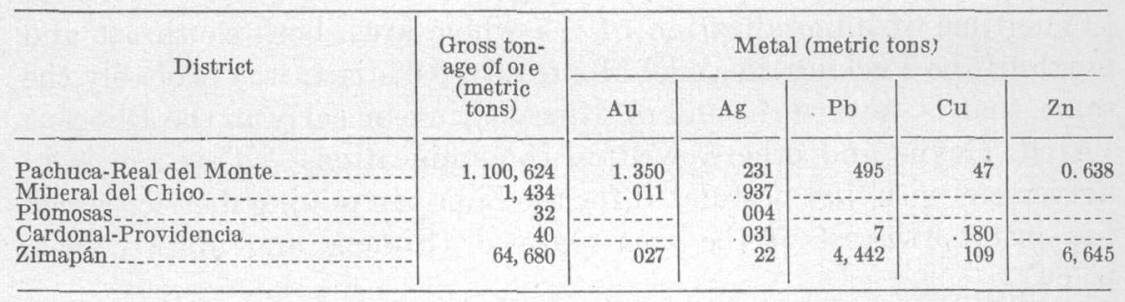

\section{NONMTETAS}

The nonmetallic mineral deposits of the area include: limestone, shale or silt-clay, and gypsite for cement manufacture; limestone and caliche for the production of quicklime and slaked lime; kaolin and feldspathic sand for the ceramics industry; building stone; pumicite; and sand, gravel, and crushed rock for highway building and other local construction uses. Of primary economic importance to the region is the cement industry, which utilizes the El Doctor and Cuautla limestones, nonmarine limestone, and silt and clay from the Tarango formation, shale from the Méndes formation, and gypsum of Quaternary age, extracted from quarries near Tula, Jasso, and Apaxco, and north of Huehuetoca, México. 


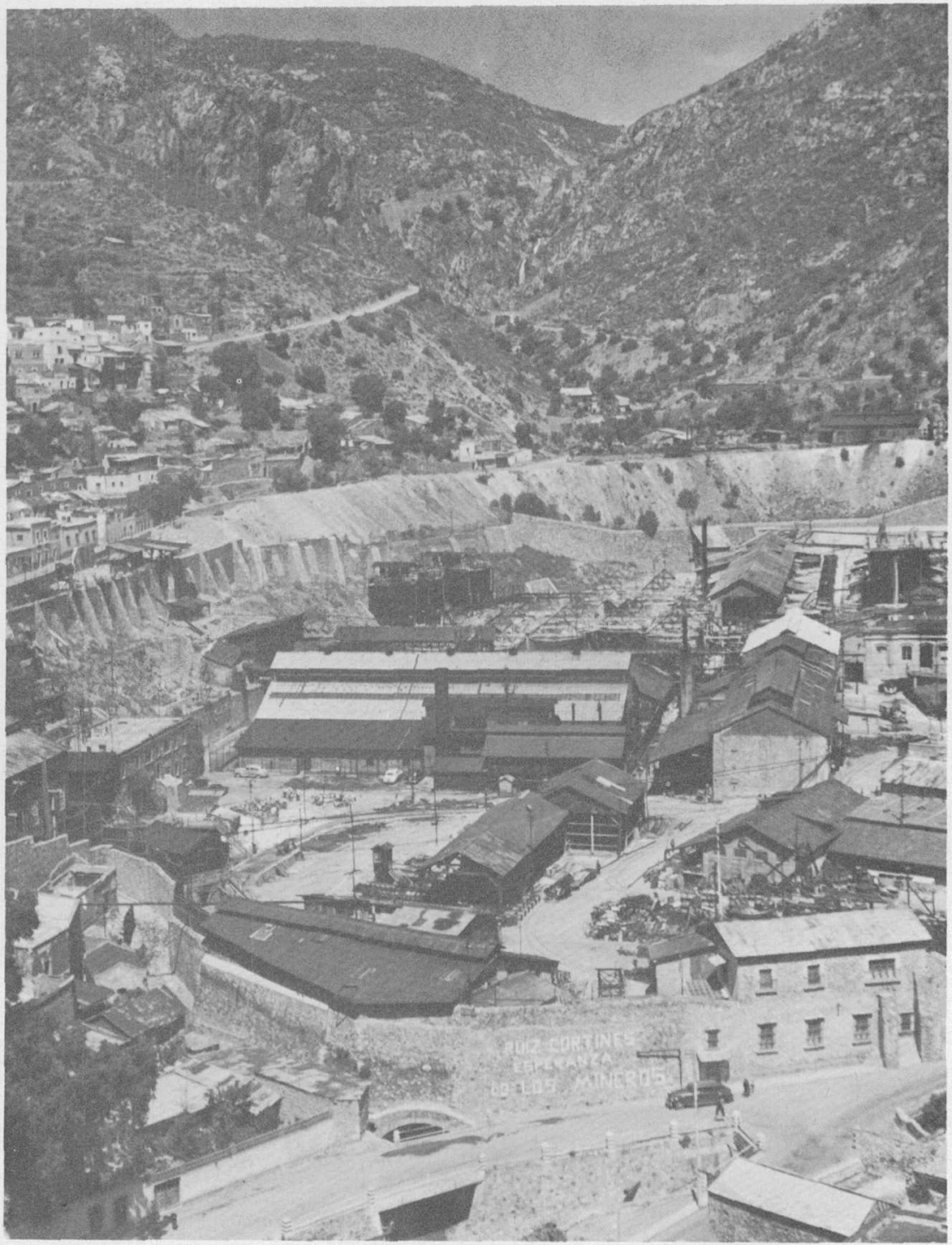

Figure 70.-Loreto mill in Pachuca, the treatment plant for ores of the Pachuca-Real del Monte mining district.

Caliche occurs in the soil and hence is not shown on plate 3 ; it is described in the section on stratigraphy. Kaolin is quarried in the Tula-A paxco area near San Bartolo, Hidalgo, and in other areas of altered rhyolite. Much of the kaolin from southeast of Tula is derived from zones of intense hydrothermal alteration within small bodies of rhyolite that intrude the El Doctor limestone (these intru- 


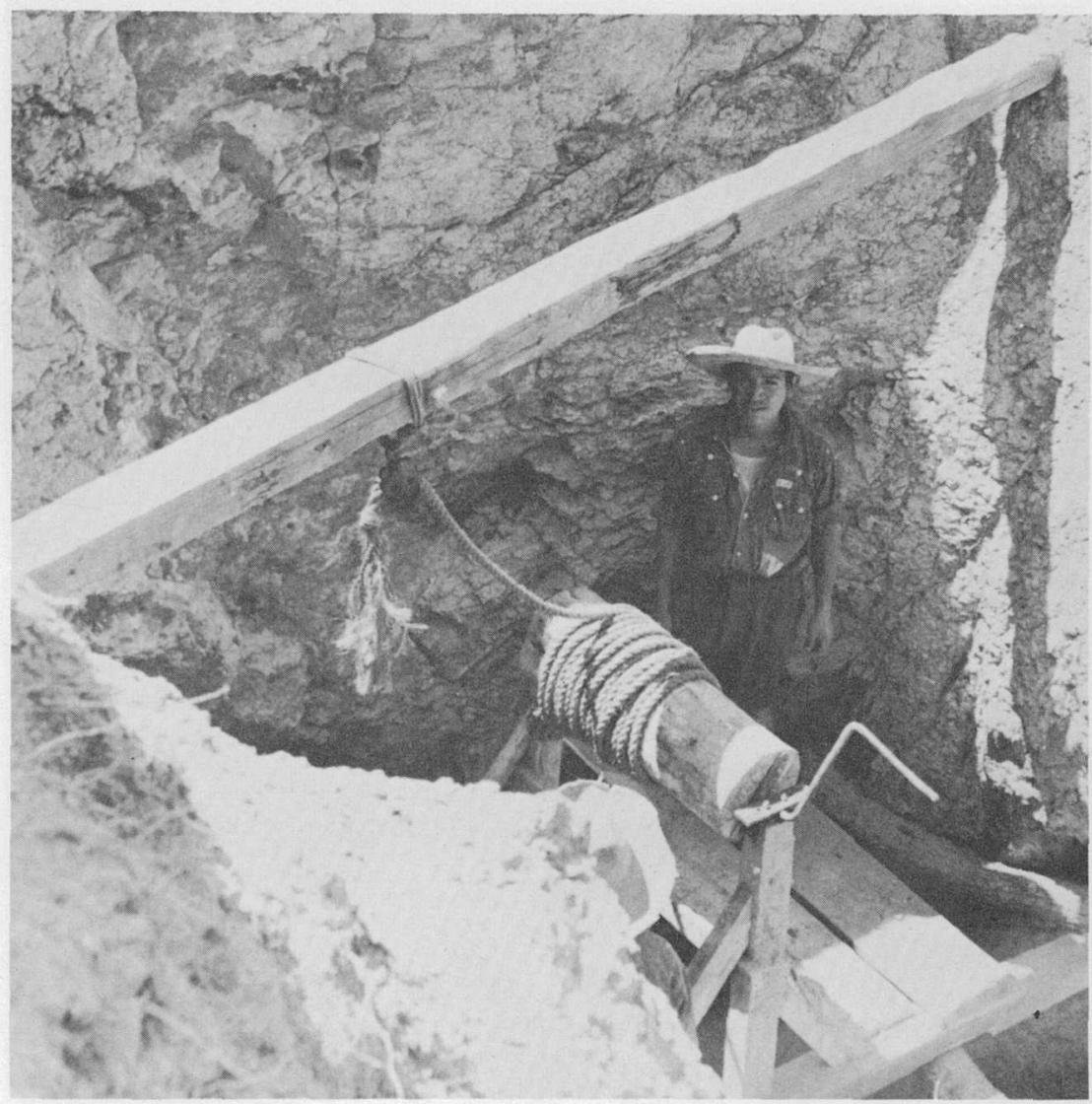

Figure 71.-El Paje, a mine shaft in the Magdalena district. This shaft is typical of those of the small mines between the Pachuca and Zimapán mining districts.

sive bodies are not shown on pl. 3). A deposit of feldspathic sand occurs $1.5 \mathrm{~km}$ northeast of Rancho Tepozán, or about $15 \mathrm{~km}$ westsouthwest of Pachuca. Welded tuff (ignimbrite) has been quarried for building stone at Cerro Xicuco, about $8 \mathrm{~km}$ northeast of Tula. A large deposit of pumicite lies in the Tarango formation between the villages of Orizabita and El Espíritu at about $12 \mathrm{~km}$ north-northeast of Ixmiquilpan (Blasquez and others, 1938, p. 133-135). Sand and gravel are almost everywhere present in valley areas. Basalt lava and agglomerate, or tezontle, for crushing and mixing with asphalt in highway surfacing, are abundant in the southern part of the area. 


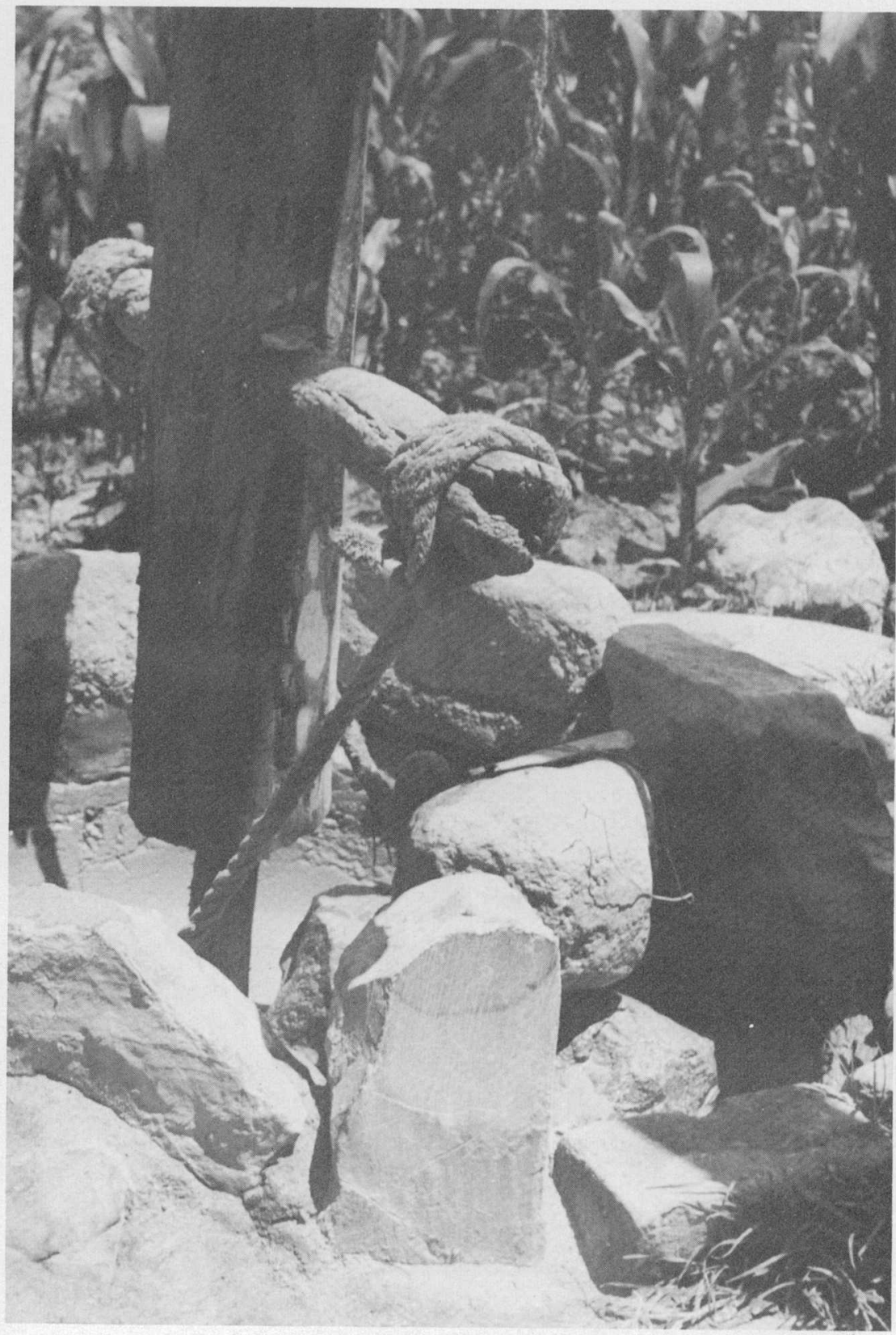

Figure 72.- Arrastre used at San Clemente, Hidalgo, to pulverize and amalgamate goldbearing ore. 
The Tula-Apaxco area supplies 85-90 percent of the raw materials for manufacture of the cement that is used in Mexico City, for it is easily accessible to that large market. Manufactured cement from Tula, Jasso, and A paxco is shipped as far north as San Luis Potosí, as far south as Acapulco, and as far east as Veracruz.

Production for the year 1955 in the Tula-Apaxco district was:

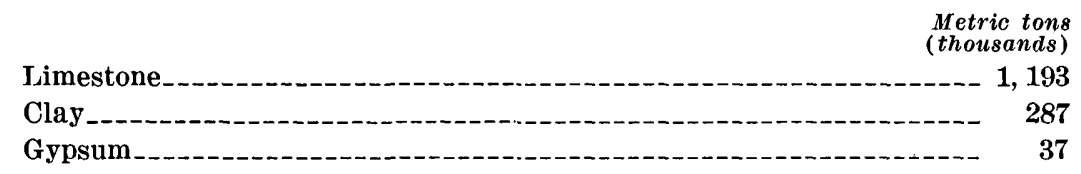

The district also was producing about 200 tons per day of calcium oxide and 30 tons of kaolin in 1956. At that time the production of these commodities was negligible in other parts of the area.

\section{THERMAL SPRINGS}

Thermal springs occur along or near the Río Tula from the vicinity of Tula to Tasquillo, Hidalgo, a stream distance of about $110 \mathrm{~km}$, at the following places: $4 \mathrm{~km}$ southeast of Tula, $1 \mathrm{~km}$ northeast of Tezontepec de Aldama, $3 \mathrm{~km}$ and $7 \mathrm{~km}$ southeast of Ixmiquilpan, $1 \mathrm{~km}$ east of Tasquillo. In addition, there is a thermal spring on the bank of the Río Salado, a tributary of the Tula, $1.5 \mathrm{~km}$ east of Atotonilco Tula, and another at the town of Ajacuba, $15 \mathrm{~km}$ to the northeast. Thermal springs also occur $4.5 \mathrm{~km}$ northwest of Atotonilco el Grande and at Grutas de Tonaltongo, both on or near large tributaries of the Río Amajac. The only thermal springs in the area that do not occur near large permanent streams are the ones near Tula and at Ajacuba. By far the largest spring is that of Grutas de Tonaltongo, whose volume is $2.5 \mathrm{cu} \mathrm{m}$ per second. The Tonaltongo spring emits a saturated solution of calcium carbonate and the Ajacuba and Tula springs are highly gypsiferous, but the other thermal waters are of low mineral content. Temperatures of the springs range from $31^{\circ} \mathrm{C}$ to $58^{\circ} \mathrm{C}$ (Blasquez and others, 1938, p. 74-76). The waters of most of the thermal springs have been piped to nearby bath houses and swimming pools that are much visited by local residents and by tourists from Mexico City and Pachuca.

\section{REFERENCES}

Arellano, A. R. V., 1953, Estratigrafía de la Cuenca de México: México Univ. Nac. Autónoma Cong. Cient. Mexicano Mem., v. 3, p. 172-186.

Balk, Robert, 1937, Structural behavior of igneous rocks: Geol. Soc. America Mem. 5, $177 \mathrm{p}$.

Bárcena, Mariano, 1875, Datos para el estudio de las rocas mesozoicas de México y sus fósiles característicos: Soc. Geografía Estadística, 3d series, v. 2, p. $371-405$. 
Blásquez López, Luis, and others, 1938, Memoria de la comisión geológica del Valle del Mezquital : Inst. Geología [México], 239 p.

Bodenlos, A. J., 1956, Notas sobre la geología de la Sierra Madre en la sección Zimapán-Tamazunchale: Internat. Geol. Cong., 20th, México, D.F., 1956, Excursions A-14 and C-6, p. 293-309.

Bonet, Federico, 1952, La facies Urgoniana del Cretácico medio de la region de Tampico: Asoc. Mexicana Geólogos Petroleros Bol., v. 4, p. 153-262.

Bryan, Kirk, 1948, Los suelos y fósiles de la altiplanicie de México, en relación a los cambios climáticos: Soc. Geol. Mexicana Bol., v. 13, p. 1-20.

Clisby, K. H., and Sears, P. B., 1955, Microfossil profiles: Geol. Soc. America Bull., v. 66, p. 511-520.

de Terra, Helmut, and others, 1949, Tepexpan Man: Viking. Fund Pubs. in Anthropology, no. 11, $160 \mathrm{p}$.

Edwards, J.D., 1955, Studies of some early Tertiary red conglomerates of Mexico : U.S. Geol. Survey Prof. Paper 264-H, p. 153-185.

Flores, Teodoro, and others, 1924, Estudio geológico de la zona minera entre los minerales de Atotonilco el Chico y Zimapán, en el Estado de Hidalgo: Inst. Geología [México] Bol. 43, 159 p.

Fries, Carl, Jr., 1956, Bosquejo geológico de la región entre México, D.F., y Taxco, Guerrero : Internat. Geol. Cong., 20th, México, D.F., 1956, Excursions A-4 and C-2, p. 11-35.

Fries, Carl, Jr., Hibbard, C. W., and Dunkle, D. H., 1955, Early Cenozoic vertebrates in the red conglomerate at Guanajuato, México: Smithsonian Misc. Coll., v. 123, no. 7, 25 p.

Hibbard, C. W., 1955, Pleistocene vertebrates from the upper Becerra formation, valley of Tequixquiac, Mexico, with notes on other Pleistocene forms: Michigan Univ. Mus. Paleontology Contr., v. 12, p. 47-96.

Imlay, R. W., 1944, Cretaceous formations of Central America and Mexico: Am. Assoc. Petroleum, Geologists Bull., v. 28, p. 1077-1195.

Jiménez-Moreno, Wigberto, 1941, Tula y los Toltecas según las fuentes históricas: Rev. Mexicana Estudios Anthropol., v. 5, nos. 2-3.

Maldonado-Koerdell, Manuel, 1948, Los vertebrados fósiles del Cuaternario en México: Soc. Mexicana Historia Nat., Rev. v. 9, 35 p.

Muir, J. M., 1936, Geology of the Tampico region, México: Tulsa, Okla., Am. Assoc. Petroleum Geologists, $280 \mathrm{p}$.

Müllerried, F. K. G., 1930, El llamado Hippurites mexicana Bárcena: Inst. Biologia Mexicana Anales, v. 1, p. 63.

1939, Apuntes paleontológicos y estratigráficos sobre el Valle del Mezquital, Estado de Hidalgo: Escuela Nac. Cienc. Biológicas Anales, v. 1, no. 2, 225-254.

1948, Fósiles raros de México, V. Un Hippurites del Valle del Mezquital, Estado de Hidalgo: Inst. Biología Mexicana Anales, v. 19, 10 p.

Rogers, C. L., and others, 1956, General geology and phosphate deposits of Concepción del Oro district, Zacatecas, Mexico : U.S. Geol. Survey Bull. 1037-A, p. 1-102.

Segerstrom, Kenneth, 1956, Estratigrãia y tectonica del Cenozoico entre México, D. F., y Zimpán, Hidalgo: Internat. Geol., 20th, México, D. F. 1956, Excursions A-3 and C-1, p. 11-22 ; Excursions A-14 and C-6, p. 311-323. 1961, Geology of the Bernal-Jalpan area, Estado de Querétaro, Mexico, U.S. Geol. Survey Bull. 1104-B, p. 19-85. 
Simons, Frank, and Mapes V., Eduardo, 1956, Geology and ore deposits of the Zimapán mining district, Hidalgo, Mexico: U.S. Geol. Survey Prof. Paper $284,128 \mathrm{p}$.

Villarello, Juan de D., and Bose, Emilio, 1902, Criaderos de fierro de la Hacienda de Vaquerías en el Estado de Hidalgo: Inst. Geología (México) Bol. 16, p. 15-44.

White, D. E., 1948, Antimony deposits of the Soyatal district, State of Querétaro, Mexico : U.S. Geol. Survey Bull. 960-B, p. 35-38.

Wilson, B. W., Herníndez, Pedro, and Meave T., Edgardo, 1955, Un arrecife cretácico en la parte oriental del Estado de Querétaro: Soc. Geol. Mexicana Bol., v. 18, p. 1-10.

Wittich, Ernesto, 1913, Observaciones geológicas en los alrededores de Atotonilco el Grande, Hidalgo: Acta Asamb. Gen. de Invierno de la Soc. Geol. Mexicana diciembre 27,1913, p. $13-14$.

- 1919, Contribución a la geologia de Atotonilco el Grande, Hidalgo: Soc. Antonio Alzate Mem. v. 38, p. 407-427.

Zeevaert, Leonardo, 1953, Estratigráfia y problemas de ingeniería en los depósitos de arcilla lacustre de la Ciudad de México: México Univ. Nac. Autónoma Cong. Cient. Mexicano Mem., v. 5, p. 58-70. 